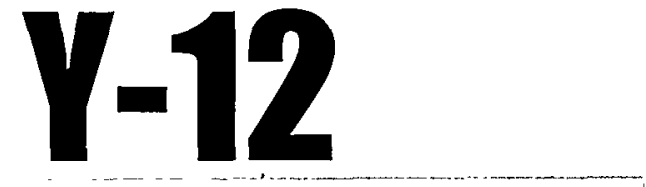

OAK RIDGE

Y-12

PLANT

LOCKHEED MA RTIUT

\section{GROUNDWATER PROTECTION PROGRAM \\ CALENDAR YEAR 1998 \\ EVALUATION OF GROUNDWATER AND \\ SURFACE WATER QUALITY DATA \\ FOR THE \\ BEAR CREEK HYDROGEOLOGIC REGIME \\ AT THE \\ U.S. DEPARTMENT OF ENERGY Y-12 PLANT, OAK RIDGE, TENNESSEE}

RECEIVED

September 1999

NOV 041999

OSTI

\section{Prepared by}

AJA TECHINICAL SERVICES, INC. Under Subcontract No. 70Y-MVM64V

for the

Environmental Compliance Department Environmental, Safety, and Health Organization Oak Ridge Y-12 Plant

Oak Ridge, Tennessee 37831

\section{Managed by}

LOCKHEED MARTIN ENERGY SYSTEMS, INC. for the U.S. Department of Energy Under Contract No. DE-AC05-84OR21400 


\section{DISCLAIMER}

This report was prepared as an account of work sponsored by an agency of the United States Government. Neither the United States Government nor any agency thereof, nor any of their employees, makes any warranty, express or implied, or assumes any legal liability or responsibility for the accuracy, completeness, or usefulness of any information, apparatus, product, or process disclosed, or represents that its use would not infringe privately owned rights. Reference herein to any specific commercial product, process, or service by trade name, trademark, manufacturer, or otherwise, does not necessarily constitute or imply its endorsement, recommendation, or favoring by the United States Government or any agency thereof. The views and opinions of authors expressed herein do not necessarily state or reflect those of the United States Government or any agency thereof. 


\section{DISCLAIMER}

Portions of this document may be illegible in electronic image products. Images are produced from the best available original document. 
GROUNDWATER PROTECTION PROGRAM CALENDAR YEAR 1998

EVALUATION OF GROUNDWATER AND SURFACE WATER QUALITY DATA FOR THE

BEAR CREEK HYDROGEOLOGIC REGIME

AT THE

U.S. DEPARTMENT OF ENERGY Y-12 PLANT, OAK RIDGE, TENNESSEE

September 1999

Prepared by

AJA TECHNICAL SERVICES, INC. Under Subcontract No. 70Y-MVM64V

for the

Environmental Compliance Department

Environmental, Safety, and Health Organization

Oak Ridge Y-12 Plant

Oak Ridge, Tennessee 37831

Managed by

LOCKHEED MARTIN ENERGY SYSTEMS, INC.

for the U.S. Department of Energy

Under Contract No. DE-AC05-84OR21400 


\section{CONTENTS}

Section

Page

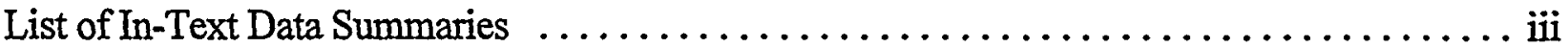

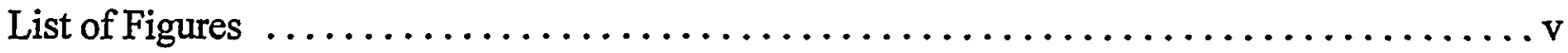

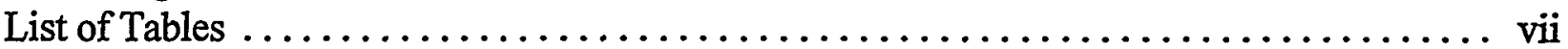

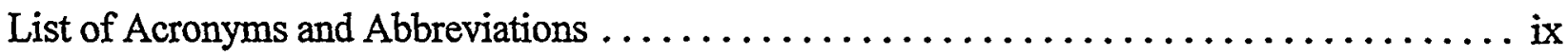

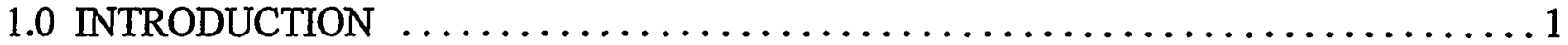

2.0 BACKGROUND INFORMATION $\ldots \ldots \ldots \ldots \ldots \ldots \ldots \ldots \ldots \ldots \ldots \ldots \ldots \ldots \ldots \ldots \ldots \ldots \ldots$

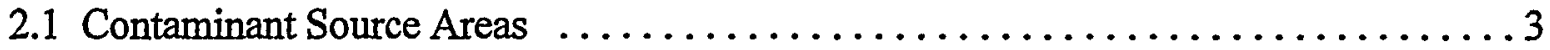

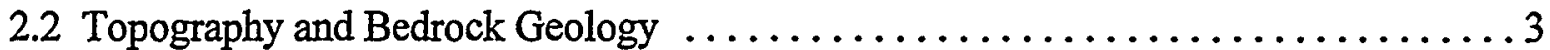

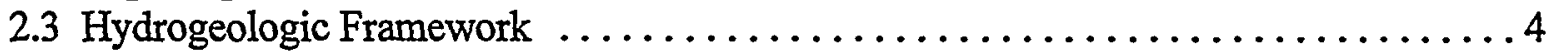

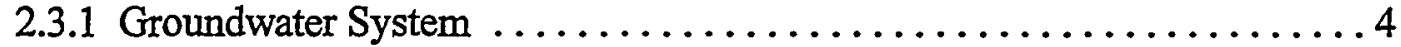

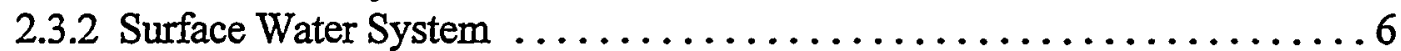

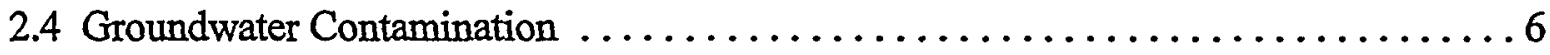

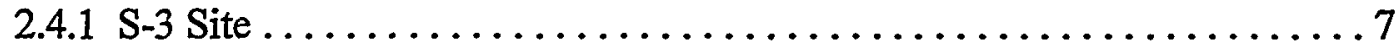

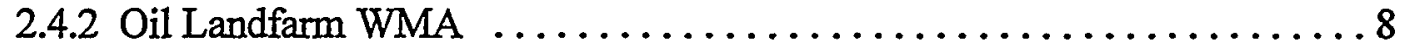

2.4.3 Bear Creek Burial Grounds WMA .................... 8

2.4.4 Maynardville Limestone Exit Pathway .................. 10

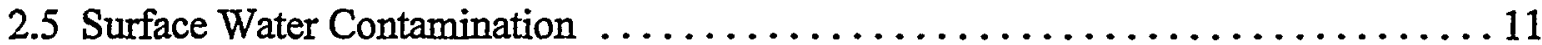

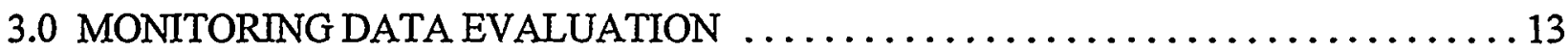

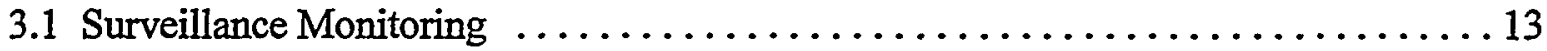

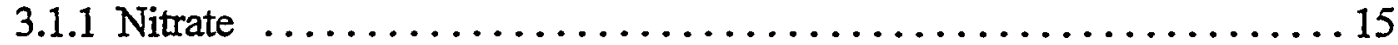

3.1 .2 Trace Metals ................................... 19

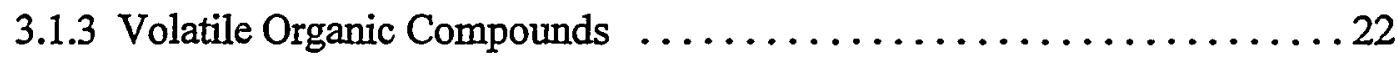

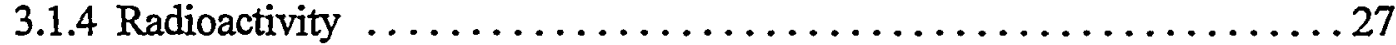

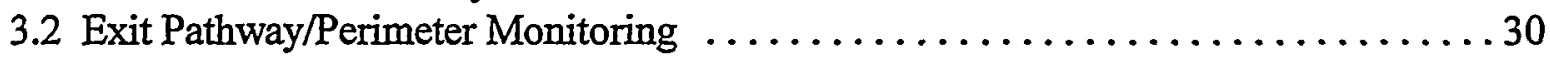

3.2.1 Upper Bear Creek . .................................. 31

3.2.2 Middle Bear Creek ................................ 32

3.2.3 Lower Bear Creek ................................... 33

3.3 Contaminant Concentration Trends .............................. 34

4.0 CONCLUSIONS AND RECOMMENDATIONS $\ldots \ldots \ldots \ldots \ldots \ldots \ldots \ldots \ldots \ldots \ldots \ldots \ldots$

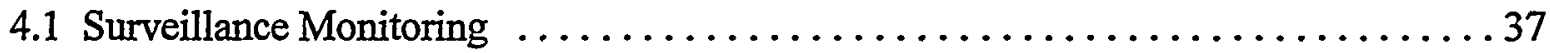

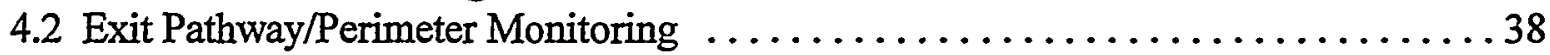

4.3 Contaminant Concentration Trends .................................. 39

4.4 Recommendations . . . . . . . . . . . . . . . . . . . . . . . . . . 39

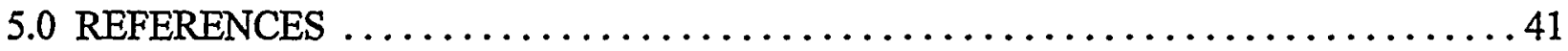

APPENDIX A: FIGURES

APPENDIX B: TABLES 


\section{List of In-Text Data Summaries}

Data Summary

Page

CY 1998 Surveillance Monitoring Well Network ..................... 13

Principal Contaminants in the CY 1998 Surveillance Monitoring Wells . . . . . . . . . 15

Summary of Nitrate Results for Surveillance Monitoring Wells .............. 16

UTLs for Barium, Boron, Strontium, and Uranium $\ldots \ldots \ldots \ldots \ldots \ldots \ldots \ldots$

Summary of CY 1998 Barium, Boron, Strontium, and Uranium Results

for Surveillance Monitoring Wells . . . . . . . . . . . . . . . . . . 20

CY 1998 Maximum VOC Concentrations That Exceed MCLs $\ldots \ldots \ldots \ldots \ldots \ldots \ldots \ldots 22$

CY 1998 Maximum Summed VOC Concentrations for

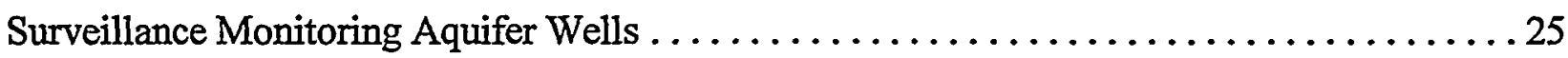

CY 1998 Gross Alpha Activity Greater Than $15 \mathrm{pCi} / \mathrm{L} \ldots \ldots \ldots \ldots \ldots \ldots \ldots$

CY 1998 Gross Beta Activity Greater Than 50 pCi/L . . . . . . . . . . . . . . . 28

CY 1998 Sampling Locations Used for Exit Pathway/Perimeter Monitoring . . . . . . . . . 30

CY 1998 Maximum Contaminant Concentrations at

Exit Pathway/Perimeter Monitoring Locations $\ldots \ldots \ldots \ldots \ldots \ldots \ldots \ldots \ldots \ldots \ldots \ldots \ldots$

Comparison of Nitrate and Uranium Concentrations at Well GW-714

Using Conventional and Low-Flow Sampling Methods . . . . . . . . . . . . . 33

CY 1998 Increasing Long-Term Concentration Trends $\ldots \ldots \ldots \ldots \ldots \ldots \ldots \ldots$ 


\section{List of Figures}

Figure

Page

1 Hydrogeologic regimes at the $\mathrm{Y}-12$ Plant $\ldots \ldots \ldots \ldots \ldots \ldots \ldots \ldots \ldots \ldots \ldots \ldots \ldots \ldots$

2 Waste management sites and regulated units in the Bear Creek

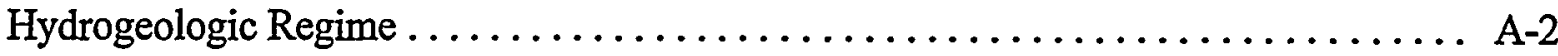

3 Topography and bedrock geology in the Bear Creek Hydrogeologic Regime ........ A-3

4 Seasonal groundwater elevations in the Bear Creek Hydrogeologic Regime, 1998 . . . A A-4

5 Generalized extent of groundwater contamination in the Bear Creek

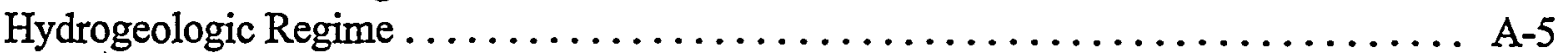

6 CY 1998 sampling locations in the Bear Creek Hydrogeologic Regime ........... A-6

7 Components of Maynardville Limestone exit pathway pickets $A, B, C$, and W ...... A-7

8 Groundwater geochemistry in the Aquitard wells sampled during CY $1998 \ldots \ldots \ldots$ A-8

9 Nitrate concentration trends in Aquitard wells GW-085, GW-537, and GW-829 ..... A-9

10 Groundwater geochemistry in the Aquifer wells sampled during CY 1998 . . . . . . A-10

11 Long-term average nitrate concentration trends in the Aquifer $\ldots \ldots \ldots \ldots \ldots \ldots$ A-11

12 Barium and strontium concentration trends in Aquitard wells GW-085, GW-537, and GW-829

13 Uranium concentration trends in Aquifer wells GW-226, GW-683, GW-684, and GW-706

14 Long-term average TCE concentration trends in the Aquifer $\ldots \ldots \ldots \ldots \ldots \ldots$ A-14

15 Long-term gross alpha activity trends in the Aquifer $\ldots \ldots \ldots \ldots \ldots \ldots \ldots$ A-15

16 Long-term gross beta activity trends in the Aquifer $\ldots \ldots \ldots \ldots \ldots \ldots \ldots \ldots$ A-16 


\section{List of Figures (continued)}

Figure

17 Nitrate concentrations and gross alpha activity trends in Bear Creek .......... A-17

18 Gross beta activity trend in Aquitard well GW- $537 \ldots \ldots \ldots \ldots \ldots \ldots \ldots \ldots$ A-18

19 VOC concentration trends in Aquitard wells GW-627 and GW-653 .......... A-19

20 Nitrate, TCE, and 1,2-DCE concentration trends in Aquifer well GW-226 . . . . . A-20

21 TCE concentration trends in Aquifer wells GW-695 and GW-724 .......... A-21

22 Nitrate concentration trend in Aquifer well GW-706 ............... A-22 


\section{List of Tables}

Table

Page

1 Waste management sites and regulated units in the

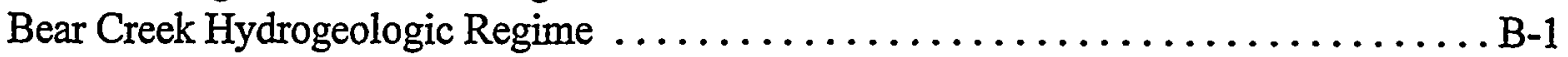

2 CY 1998 groundwater and surface water sampling locations and dates .......... B-3

3 Field measurements and laboratory analytes for CY 1998 groundwater

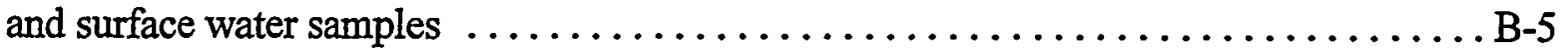

4 CY 1998 maximum summed VOC concentrations in groundwater samples .......... B-9

5 CY 1998 gross alpha and gross beta activity in groundwater and surface water samples 


\section{List of Acronyms and Abbreviations}

$\begin{array}{ll}\text { AGLLSF } & \text { Above Grade Low-Level Storage Facility } \\ \text { BCBG } & \text { Bear Creek Burial Grounds } \\ \text { BCV } & \text { Bear Creek Valley } \\ \text { BCK } & \text { Bear Creek kilometer } \\ \text { Bear Creek Regime } & \text { Bear Creek Hydrogeologic Regime } \\ \text { BG } & \text { Burial Ground } \\ \text { bgs } & \text { below ground surface } \\ \text { CERCLA } & \text { Comprehensive Environmental Response, Compensation, and Liability Act } \\ \text { CY } & \text { calendar year } \\ \text { DNAPL } & \text { dense nonaqueous phase liquids } \\ \text { DOE } & \text { U.S. Department of Energy } \\ \text { DQO } & \text { data quality objective } \\ \text { East Fork Regime } & \text { Upper East Fork Poplar Creek Hydrogeologic Regime } \\ \text { ft } & \text { feet } \\ \text { GWMR } & \text { Groundwater Monitoring Report } \\ \text { GWPP } & \text { Groundwater Protection Program } \\ \text { HCDA } & \text { Hazardous Chemical Disposal Area } \\ \text { MCL } & \text { maximum contaminant level } \\ \text { MDA } & \text { minimum detectable activity } \\ \text { msl } & \text { mean sea level } \\ \mu g / L & \text { micrograms per liter } \\ \text { mg/L } & \text { milligrams per liter } \\ \text { NT } & \text { North Tributary (Bear Creek) } \\ \text { ORR } & \text { Oak Ridge Reservation } \\ \text { PCE } & \text { tetrachloroethene } \\ \text { pCi/L } & \text { picoCuries per liter } \\ \text { RCRA } & \text { Resource Conservation and Recovery Act } \\ \text { REDOX } & \text { oxidation-reduction potential } \\ \text { RI } & \text { Remedial Investigation } \\ \text { SDWA } & \text { Safe Drinking Water Act } \\ \text { SS } & \text { south side (Bear Creek) } \\ \text { TCE } & \text { trichloroethene } \\ \text { TDS } & \text { total dissolved solids } \\ \text { UTL } & \text { upper tolerance limit } \\ \text { VC } & \text { vinyl chloride } \\ \text { VOC } & \text { volatile organic compound } \\ \text { WMA } & \text { Waste Management Area } \\ & \end{array}$


List of Acronyms and Abbreviations (continued)

1,1-DCA

1,1-dichloroethane

1,1-DCE

1,1-dichloroethene

1,2-DCE

1,2-dichloroethene

1,2-DCA

1,2-dichloroethane

cis-1,2-DCE

cis-1,2-dichloroethene

trans-1,2-DCE trans-1,2-dichloroethene

1,1,1-TCA

1,1,1-trichloroethane

${ }^{99} \mathrm{Tc}$

${ }^{234} \mathrm{U}$

technetium-99

uranium-234

${ }^{238} \mathrm{U}$

uranium-238 


\subsection{INTRODUCTION}

This report presents an evaluation of the water quality monitoring data obtained by the Y-12 Plant Groundwater Protection Program (GWPP) in the Bear Creek Hydrogeologic Regime (Bear Creek Regime) during calendar year (CY) 1998. The Bear Creek Regime contains many confirmed and potential sources of groundwater and surface water contamination associated with the U.S. Department of Energy (DOE) Oak Ridge Y-12 Plant. Applicable provisions of DOE Order 5400.1A - General Environmental Protection Program - require evaluation of groundwater and surface water quality near the Y-12 Plant to: (1) gauge groundwater quality in areas that are, or could be, affected by plant operations, (2) determine the quality of surface water and groundwater where contaminants are most likely to migrate beyond the DOE Oak Ridge Reservation (ORR) property line, and (3) identify and characterize long-term trends in groundwater quality. The following sections of this report contain relevant background information (Section 2.0); describe the results of the respective data evaluations required under DOE Order 5400.1A (Section 3.0); summarize significant findings of each evaluation (Section 4.0); and list the technical reports and regulatory documents cited for more detailed information (Section 5.0). All of the figures (maps and trend graphs) and data tables referenced in each section are presented in Appendix A and Appendix B, respectively. 


\subsection{BACKGROUND INFORMATION}

The Bear Creek Regime encompasses several confirmed and suspected sources of groundwater and surface water contamination within Bear Creek Valley (BCV) west of the DOE Y-12 Plant in Oak Ridge, Tennessee (Figure 1); unless otherwise noted, directions are in reference to the Y-12 Plant grid system. The following sections provide background information regarding sources of contamination, an overview of the groundwater flow and surface water drainage characteristics, and the extent of groundwater and surface water contamination in the regime.

\subsection{Contaminant Source Areas}

The Bear Creek Regime encompasses a portion of BCV used since the early 1950s for the treatment, storage, and disposal of various hazardous and nonhazardous wastes (Figure 2). Many of the sites are confirmed or suspected sources of groundwater and surface water contamination, with the primary sources being the S-3 Site (formerly the S-3 Ponds), the Oil Landfarm waste management area (WMA), which includes the Boneyard/Burnyard/Hazardous Chemical Disposal Area (HCDA), and the Bear Creek Burial Grounds (BCBG) WMA. All of the sites except the Above Grade LowLevel Storage Facility (AGLLSF) have undergone some level of engineered closure (e.g., installation of multilayer, low-permeability caps) and are currently regulated under the Resource Conservation and Recovery Act (RCRA), the Comprehensive Environmental Response, Compensation, and Liability Act (CERCLA), or both. The AGLLSF is an operating facility that is not regulated under either program (Table 1). Contaminated receptor media in the regime (groundwater, surface water, and Bear Creek stream sediments and floodplain soils) are also regulated under CERCLA.

\subsection{Topography and Bedrock Geology}

The Bear Creek Regime is bound to the north by Pine Ridge and to the south by Chestnut Ridge and encompasses the portion of $\mathrm{BCV}$ extending from a surface water and shallow groundwater divide at the west end of the Y-12 Plant to the western boundary of the Bear Creek watershed. Surface elevations range from 900 feet (ft) above mean sea level (msl) in the Bear Creek channel along the floor of $\mathrm{BCV}$ to about $1,200 \mathrm{ft}$ msl along the crests of Pine Ridge and Chestnut Ridge (Figure 3).

The geology of the Bear Creek Regime is characterized by alternating sequences of clastic and carbonate strata that form the distinctive topography of the Valley and Ridge Physiographic Province. On the ORR, shale and siltstone beds of the Rome Formation form Pine Ridge to the north, limestone and shale formations of the Conasauga Group form BCV, and the primarily dolostone formations of the Knox Group form Chestnut Ridge to the south (Figure 3). Strike and dip of bedding are generally $\mathrm{N} 55^{\circ} \mathrm{E}$ and $45^{\circ} \mathrm{SE}$, respectively (as referenced to true north). Bedrock is overlain by up to $50 \mathrm{ft}$ of several materials, including man-made fill, alluvium, colluvium, finegrained residuum from the weathering of the bedrock, and saprolite (weathered bedrock). 


\subsection{Hydrogeologic Framework}

The following overview of the groundwater and surface water systems in the Bear Creek Regime is based on the conceptual hydrogeologic model described in the CERCLA remedial investigation (RI) report for the Bear Creek Characterization Area (DOE 1997), which is hereafter referenced as the RI Report. This conceptual model incorporates (1) the general hydrologic framework and associated nomenclature described in Solomon et al. (1992); (2) groundwater flow characteristics presented in Moore (1988 and 1989) and Moore and Toran (1.992); (3) results of hydrologic studies and investigations in BCV, including Dreier et al. (1987), Shevenell (1994), and Turner et al. (1991); and (4) findings of sampling and analysis activities performed specifically for RI purposes. Key aspects of the conceptual model regarding the principal hydrogeologic units and respective groundwater flow characteristics and the general hydrology of Bear Creek are summarized in the following discussion.

\subsubsection{Groundwater System}

There are two basic hydrogeologic units in the Bear Creek Regime: the Aquifer, consisting of the Maynardville Limestone (upper Conasauga Group) and Copper Ridge Dolomite (lower Knox Group); and the Aquitard, consisting of the remaining Conasauga Group formations (Nolichucky Shale, Maryville Limestone, Rogersville Shale, Rutledge Limestone, and Pumpkin Valley Shale) and the Rome Formation (Figure 3). Components of the Aquifer underlie the axis of BCV (Maynardville Limestone) and the steep flank and crest of Chestnut Ridge (Copper Ridge Dolomite). Formations comprising the Aquitard form the northern slope of BCV (Conasauga Group) and Pine Ridge (Rome Formation). The Aquitard, which underlies the primary contaminant source areas in the Bear Creek Regime, is hydraulically upgradient of the Aquifer, which functions as a hydrologic drain in BCV. Fractures provide the principal groundwater flowpaths in both units, and dissolution of carbonates in the Aquifer has enlarged fractures and produced solution cavities and conduits that greatly enhance its hydraulic conductivity relative to the Aquitard. Although negligible in both units, flow through the porous rock matrix plays an important role in contaminant migration because of matrix diffusion processes.

Groundwater flow in the Aquitard and the Aquifer is primarily parallel to bedding (along strike and dip), which in the Aquitard may or may not coincide with the direction of maximum hydraulic gradient inferred from water level isopleths. Flow across bedding occurs primarily along permeable zones formed by cross-cutting fractures or fracture zones (and possibly small faults). The northern tributaries of Bear Creek are possibly the surficial expression of these cross-cutting structures. Such structures provide preferred flowpaths that channel groundwater from the Aquitard to the Aquifer or act as barriers to lateral flow, causing groundwater from deeper intervals to upwell and discharge to the shallower flow system in each hydrogeologic unit.

In the Aquitard most groundwater flow occurs in a highly conductive interval near the bedrock/residuum interface. Flow above the water table occurs in response to precipitation when flowpaths in the residual soils become saturated and rapidly transmit water laterally (stormflow) down slope toward springs and seeps and vertically (recharge) to the water table interval. Recharge to the water table interval promotes strike-parallel groundwater flow toward discharge areas in 
nearby northern tributaries of Bear Creek. Although the presence of contaminants in groundwater more than $200 \mathrm{ft}$ below ground surface (bgs) in the Nolichucky Shale clearly indicates permeable flowpaths at depth, flow is most active at depths less than $100 \mathrm{ft} \mathrm{bgs,} \mathrm{and} \mathrm{only} \mathrm{a} \mathrm{small} \mathrm{percentage}$ of total flow ultimately recharges the deeper bedrock, where upward hydraulic gradients predominate. Overall, about $94 \%$ of the available groundwater in the Aquitard discharges to Bear Creek tributaries, about $5 \%$ flows along cross-cutting fractures into the Aquifer, and about $1 \%$ flows through strike-parallel pathways in the deeper subsurface (DOE 1997).

Decreasing groundwater flux with depth in the Aquitard also is reflected by distinct changes in groundwater geochemistry. Most water table interval and shallow (i.e., $<100 \mathrm{ft}$ bgs) bedrock wells monitor calcium-magnesium-bicarbonate groundwater. A fairly abrupt change to sodiumbicarbonate groundwater, which is interpreted to be a function of longer groundwater residence time related to reduced fracture aperture or increased fracture spacing (Solomon et al. 1992), occurs at a depth of about $100 \mathrm{ft}$ bgs. Further reduced groundwater flux is indicated by the transition from sodium-bicarbonate groundwater to sodium-chloride groundwater that usually occurs at a depth of about $400 \mathrm{ft}$ bgs. The transition to the sodium-chloride groundwater is accompanied by a general increase in total dissolved solids (TDS).

Most groundwater flow in the Aquifer occurs at shallow depths (i.e., $<100 \mathrm{ft} \mathrm{bgs)} \mathrm{in} \mathrm{an} \mathrm{extensively}$ interconnected network of solution conduits and cavities (karst network). Below the shallow karst network, fractures provide the primary flowpaths. Also, there are seven stratigraphic zones in the Maynardville Limestone (numbered from bottom to top) that are differentiated by distinct lithologic and hydrologic characteristics (Shevenell et al. 1995). The more permeable zones are at the bottom (Zone 2) and top (Zone 6) of the formation, but the uppermost zones are the most permeable and probably transmit the bulk of the groundwater in the Maynardville Limestone (Goldstrand 1995). Groundwater geochemistry is more homogeneous in the Aquifer than in the Aquitard; almost every monitoring well in the Maynardville Limestone, regardless of depth, monitors calcium-magnesiumbicarbonate groundwater. Some shallow wells monitor sulfate-enriched groundwater, which probably reflects dissolution of locally disseminated sulfides, and several deep wells monitor calcium-magnesium-sulfate groundwater with very high TDS.

Flow in the shallow karst network in the Aquifer is relatively rapid and occurs as "quickflow" discharge to Bear Creek during rainfall. Active groundwater circulation occurs at greater depth than in the Aquitard, and groundwater from the deeper flow system discharges along major gaining (influent) reaches of Bear Creek. These discharge areas are probably related to large-scale structural (e.g., cross-strike faults) or stratigraphic discontinuities in the Maynardville Limestone. Overall, about $81 \%$ of the available groundwater in the Aquifer (Maynardville Limestone) discharges directly to Bear Creek, $16 \%$ flows into the creek from spring SS-5, and 3\% follows strike-parallel flowpaths in the subsurface (DOE 1997).

Isopleths of seasonal groundwater surface elevations in the Bear Creek Regime during CY 1998 (Figure 4) indicate generally southwesterly flow in the Aquitard toward the Aquifer (Maynardville Limestone) and westerly (strike-parallel) flow in the Aquifer toward the west end of BCV. Seasonal water level fluctuations, which were typically less than $10 \mathrm{ft}$ in most water table interval and bedrock 
interval monitoring wells, influenced the magnitude of hydraulic gradients but did not significantly alter the overall groundwater flow patterns.

\subsubsection{Surface Water System}

Surface water in the Bear Creek Regime is drained by Bear Creek and its tributaries (Figure 3). From its headwaters near the west end of the Y-12 Plant, Bear Creek flows southwest for approximately 4.5 miles, where it turns northward to flow into East Fork Poplar Creek. Monitoring locations along the main channel of Bear Creek are specified by the Bear Creek kilometer (BCK) value corresponding to the distance upstream from the confluence with East Fork Poplar Creek (e.g., BCK-09.40). Sections of the main channel are referenced as upper Bear Creek (upstream of BCK-11.97), middle Bear Creek (between BCK-11.97 and BCK-09.40), and lower Bear Creek (downstream of BCK-09.40). Tributaries are designated as north tributary (NT) or south tributary along with a value representing the tributary number counted downstream from the headwaters (e.g., NT-1). Major springs along the south side (SS) of Bear Creek are numbered in ascending order downstream from the headwaters (e.g., SS-1).

Approximately half of the annual precipitation in BCV exits via surface water flow in Bear Creek, and possibly higher proportions during winter and early spring (DOE 1997). Flow in the creek increases rapidly during rainfall and afterward reflects the relative contributions of overland flow, stormflow, and groundwater discharge. Flow in the rnain channel and tributaries generally returns to pre-precipitation levels within one or two days. Major sections of upper and middle Bear Creek are seasonally dry, but flow is perennial in lower Bear Creek.

The main channel of Bear Creek functions as a major conduit of the shallow karst network within the Maynardville Limestone (DOE 1997). Discharge from numerous springs located along the Maynardville Limestone/Copper Ridge Dolomite boundary on the north slope of Chestnut Ridge dominate the hydrology of the creek, especially during droughts when they provide most of the flow in the main channel. Additionally, the main channel contains alternating gaining and losing reaches. Each gaining reach generally correlates with a major Aquifer discharge area. Losing reaches in upper and middle Bear Creek, particularly a section of the main channel directly south of Sanitary Landfill I, play an important role in transferring contaminants from Bear Creek to the Aquifer.

\subsection{Groundwater Contamination}

The following discussion is based on the contaminant transport models for the primary source areas in the Bear Creek Regime (the S-3 Site, the Oil Landfarm WMA, and the BCBG WMA) and the principal contaminant migration pathways (the Maynardville Limestone and Bear Creek) described in the RI Report. These models incorporate the bulk of the geologic, hydrologic, and water quality data available for the Y-12 Plant and essentially represent the culmination of hydrogeologic characterization and contamination assessment efforts performed since the mid-1980s. 


\subsubsection{S-3 Site}

Operation of the former S-3 Ponds emplaced a large reservoir of contamination in the Aquitard (Nolichucky Shale) consisting of a heterogeneous mix of inorganic, organic, and radioactive constituents. The principal groundwater contaminants are nitrate, technetium- $99\left({ }^{99} \mathrm{Tc}\right)$, uranium isotopes (primarily ${ }^{234} \mathrm{U}$ and ${ }^{238} \mathrm{U}$ ), trace metals (e.g., cadmium), and volatile organic compounds (VOCs). Contaminant concentrations in the Aquitard nearest the site have probably reached maximum levels, with the center of mass of the plume slowly moving westward. Westward, strike parallel migration of contaminants in the Aquitard occurs until they encounter a cross-cutting structure that promotes upward discharge into the shallow flow system, or cross-strike flow into the Aquifer.

As indicated by the distribution of nitrate, which is a highly mobile and chemically stable contaminant that delineates the maximum extent of groundwater transport and effectively traces the principal migration pathways, the S-3 Site contaminant plume in the Aquitard extends south toward the upper reach of Bear Creek, and along strike in the water table interval and the deeper bedrock for over $3,000 \mathrm{ft}$ to the west (Figure 5). Nitrate (as N) concentrations (hereafter synonymous with "nitrate" concentrations) within the plume exceed 10,000 milligrams per liter (mg/L) in the deep bedrock directly below the S-3 Site, $1,000 \mathrm{mg} / \mathrm{L}$ in the shallow groundwater near the site, and $10 \mathrm{mg} / \mathrm{L}$ near the plume boundaries.

Gross alpha activity and gross beta activity within the S-3 Site contaminant plume exceed 1,000 picoCuries per liter $(\mathrm{pCi} / \mathrm{L})$. Although a diverse population of radioisotopes is present in the groundwater closest to the site, elevated gross alpha and gross beta activity in the groundwater (Figure 5) probably delineate migration of uranium isotopes and ${ }^{99} \mathrm{Tc}$, respectively.

Other components of the S-3 Site contaminant plume are trace metals and VOCs. The distribution of trace metals is less extensive than that of nitrate and radioactivity, but the most mobile metals within the plume (e.g., barium) have been transported beyond the acidic groundwater $(\mathrm{pH}<5)$ nearest the site. Acetone and tetrachloroethene (PCE) are the principal VOCs within the plume. Concentrations of PCE exceed 5,000 micrograms per liter $(\mu \mathrm{g} / \mathrm{L})$ in wells adjacent to the site, indicating the presence of dense nonaqueous phase liquids (DNAPLs) in the subsurface, but decrease to less than $50 \mu \mathrm{g} / \mathrm{L}$ about $500 \mathrm{ft}$ downgradient of the site.

The S-3 Site contains varying amounts of sludge produced by denitrification of the waste water during closure of the former S-3 Ponds. Sludge within the saturated zone may release ${ }^{99} \mathrm{Tc}$ and uranium isotopes to the shallow groundwater flow system in the Aquitard, which then may be transported westward through the water table interval toward discharge points in NT-1 (DOE 1997). Additionally, matrix diffusion and advective transport processes are slowly releasing contaminants (e.g., nitrate) from the deeper reservoir into the more active (shallow) Aquitard flow system. 


\subsubsection{Oil Landfarm WMA}

The primary sources of groundwater contaminants in the Oil Landfarm WMA (listed in order of importance) are the Boneyard/Burnyard/HCDA, the Oil Landfarm, and Sanitary Landfill I (Table 1). Each of these sites is a source of VOCs in the shallow groundwater, and the Boneyard/Burnyard/HCDA is a major source of elemental uranium and alpha radioactivity.

Uranium isotopes are the principal groundwater contaminants at the Boneyard/Burnyard. Contamination delineated by soil sampling and geophysical and radiological surveys indicate a major source area located immediately northwest of the HCDA cap. Wastes in the Boneyard/Burnyard are probably within the saturated zone during seasonally high groundwater levels, and uranium isotopes may be leached and transported with the shallow groundwater that discharges into NT-3 or recharges directly into the Maynardville Limestone. Gross alpha and gross beta activity exceed $1,000 \mathrm{pCi} / \mathrm{L}$ in the shallow groundwater along NT-3 from the northwest corner of the site to the confluence of NT-3 and Bear Creek (Figure 5).

The Boneyard/Burnyard/HCDA also is the source of a dissolved VOC plume in the shallow groundwater. Primary components of the plume are trichloroethene (TCE), cis-1,2-dichloroethene (cis-1,2-DCE), and PCE. Concentrations of these VOCs are less than $1 \%$ of solubility, indicating that DNAPLs are probably not present in the subsurface. Because the high gross alpha and beta levels in surface water at NT-3 characterize the plume originating from the Boneyard/Burnyard (Figure 5), the lack of VOCs in these samples indicate that the HCDA is most likely the principal source of these VOCs.

Groundwater contaminants at the Oil Landfarm are principally VOCs, and a commingled plume containing two distinct suites of VOCs are evident: one to the northeast dominated by 1,1,1-trichloroethane (1,1,1-TCA), 1,1-dichloroethane (1,1-DCA), and 1,1-dichloroethene (1,1-DCE); and one to the south dominated by PCE, cis-1,2-DCE, trans-1,2-dichloroethene (trans-1,2-DCE), and TCE. The dissolved VOC plume appears to be restricted to the shallow flow system. Summed VOC concentrations exceed $1,000 \mu \mathrm{g} / \mathrm{L}$ in the northeast part of the plume and $100 \mu \mathrm{g} / \mathrm{L}$ in the southern part of the plume; maximum concentrations within the plume do not indicate the presence of DNAPLs in the subsurface.

Sanitary Landfill I is a probable source of 1,1-DCA, cis-1,2-DCE, and trans-1,2-DCE in the shallow groundwater (Aquitard and Aquifer) downgradient to the south of the site (Figure 4). Maximum VOC concentrations are typically less than $50 \mu \mathrm{g} / \mathrm{L}$. In the Aquifer (Maynardville Limestone), these constituents have intermingled with the VOC plume (primarily TCE and cis-1,2-DCE) originating from upgradient sources. Sanitary Landfill I also may be a source of boron in the groundwater at several wells immediately downgradient (west) of the site.

\subsubsection{Bear Creek Burial Grounds WMA}

Groundwater in the Aquitard underlying the BCBG WMA is extensively contaminated with VOCs at both shallow (water table) and deep (bedrock) intervals (Figure 5). There are five primary source 
areas: Burial Ground (BG)-A (North and South), BG-C (East and West), and the Walk-In Pits (Table 1). Dissolved VOC plumes in the shallow groundwater at several of these source areas are probably related to widespread occurrence of DNAPLs in the subsurface. Contamination in the deeper groundwater flow system reflects density-driven, downward migration of DNAPLs.

The disposal trenches comprising BG-A (North and South) received almost two million gallons of waste oils and coolants, and DNAPLs have been encountered at $260 \mathrm{ft}$ and $330 \mathrm{ft}$ bgs in monitoring wells downdip of source trenches in BG-A South. Dissolved VOC plumes in the groundwater underlying both areas are dominated by PCE, TCE, and cis-1,2-DCE. Other common plume constituents are 1,1,1-TCA, 1,1-DCA, and 1,2-dichloroethane (1,2-DCA). Summed concentrations of these plume constituents exceed $100,000 \mu \mathrm{g} / \mathrm{L}$. Groundwater in the water table interval transports the plume constituents along strike toward discharge areas in NT-7. Strike-parallel migration also occurs below the water table interval, as reflected by westward (strike-parallel) transport of PCE indicated by data obtained from deeper bedrock wells at BG-A South.

Separate plumes of dissolved VOCs apparently occur in the shallow groundwater at BG-C East and BG-C West (Figure 5), both dominated by cis-1,2-DCE with lesser amounts of vinyl chloride (VC). Concentrations within the plume are generally less than $500 \mu \mathrm{g} / \mathrm{L}$. Groundwater containing these VOCs discharges to the NT-8 catchment on the northwest side of the Burial Grounds WMA. Data for both source areas do not clearly indicate the presence of DNAPLs in the subsurface.

Groundwater near the Walk-In Pits contains a distinct plume of dissolved VOCs dominated by PCE. Concentrations exceed $2,000 \mu \mathrm{g} / \mathrm{L}$, which is about $1 \%$ of the maximum PCE solubility and possibly indicates DNAPLs in the subsurface. Contaminants in the shallow groundwater flow system may not discharge extensively to surface water (DOE 1997).

Although large quantities of uranium wastes were disposed in the BCBG WMA, few monitoring wells in the area yield radioactive groundwater samples (Figure 5). However, RI data for soil samples and surface water samples collected from Bear Creek tributaries NT-6, NT-7, and NT-8 indicate that BG-A South and BG-C East are probable sources of radioactivity. Maximum gross alpha and gross beta activities in the samples from these tributaries ranged from about $20 \mathrm{pCi} / \mathrm{L}$ to more than $100 \mathrm{pCi} / \mathrm{L}$. The disparity with the groundwater sample data may be an artifact of the monitoring well network (few wells are screened within the shallowest water table interval where radioactive contamination likely occurs), but the relatively low levels of radioactivity in the groundwater also suggest that the bulk of the uranium wastes in BG-A. South and BG-C East are not within the saturated zone (DOE 1997).

Boron is the primary trace metal contaminant in the groundwater at the BCBG WMA. Elevated boron concentrations occur primarily in the shallow groundwater near BG-A South and BG-C (East and West) and probably resulted from disposal of borax wastewater from the Y-12 Plant. Boron is most likely present in the groundwater as borate $\left[\mathrm{B}(\mathrm{OH})_{3}\right]$, which is chemically stable and relatively mobile, and is transported toward discharge points in Bear Creek tributaries NT-7 and NT-8. 


\subsubsection{Maynardville Limestone Exit Pathway}

The principal groundwater contaminants in the Maynardville Limestone are nitrate, VOCs, radioactivity, and trace metals. These contaminants primarily originate from the S-3 Site (nitrate, trace metals, and radionuclides), the Boneyard/Burnyard/HCDA (uranium isotopes and VOCs), Sanitary Landfill I (VOCs), the BCBG WMA (VOCs and radionuclides), and the Rust Spoil Area (VOCs) or an unidentified (VOC) source area in the Bear Creek floodplain adjacent to the Rust Spoil Area. These contaminants enter the Maynardville Limestone through direct recharge, hydrologic communication with surface water in Bear Creek, and inflow of shallow groundwater from the Aquitard. Relative contributions from the source areas and the geochemical characteristics of the contaminants have produced two primary plumes of contamination in the groundwater: one containing nitrate and radioactivity and another containing VOCs. Both occur in both the shallow karst network and the deeper fracture flowpaths and are commingled downgradient of the Boneyard/Burnyard/HCDA. Trace metal contaminants are more sporadically distributed and chiefly occur in the shallow karst network near the primary source areas (S-3 Site, Boneyard/Burnyard/ HCDA, and BCBG WMA).

The nitrate plume in the Aquifer essentially delineates the maximum extent of contaminant transport and effectively traces the primary migration pathways in the Maynardville Limestone (Figure 5). The plume is continuous in the deeper bedrock from south of the S-3 Site for about $10,000 \mathrm{ft}$ along strike to the west, whereas attenuation from more active recharge and groundwater flux has reduced nitrate levels and produced a more discontinuous plume in the shallow karst network. Nitrate concentrations within the plume exceed $500 \mathrm{mg} / \mathrm{L}$ south of the $\mathrm{S}-3$ Site, but rapidly decrease to less than $50 \mathrm{mg} / \mathrm{L}$ south of the Oil Landfarm WMA, and are typically highest in the fracture-dominated groundwater flow system at depths greater than $100 \mathrm{ft}$ bgs.

The distribution of VOCs in the Maynardville Limestone reflects the relative contributions of several source areas and commingling during downgradient transport (Figure 5). Plume constituents in the upper part of BCV are TCE, cis-1,2-DCE, and PCE; probable source areas are Spoil Area I, the S-3 Site, and possibly the Fire Training Facility located in the Upper East Fork Poplar Creek Hydrogeologic Regime (East Fork Regime). The major inputs to the plume occur from the Rust Spoil Area (TCE) or a nearby source in the Bear Creek floodplain, the Boneyard/Burnyard/HCDA (TCE and cis-1,2-DCE), Sanitary Landfill I (1,1,1-TCA and 1,1-DCA), and discharge from the Bear Creek tributary (NT-7) that traverses BG-A North and A South (cis-1,2-DCE and 1,2-DCA). The highest concentrations within the plume (i.e., $>300 \mu \mathrm{g} / \mathrm{L}$ ) occur in the deeper groundwater south (down dip) of the Boneyard/Burnyard. These high concentrations coincide with the downward vertical hydraulic gradients in the Maynardville Limestone in this area and the major losing reach of middle Bear Creek south of Sanitary Landfill I.

Radioactivity in the groundwater in the Maynardville Limestone is primarily from uranium isotopes and ${ }^{99} \mathrm{Tc}$. The extent of these radionuclides are generally delineated by gross alpha activity and gross beta activity, respectively. The distribution of gross beta activity mirror that of nitrate, indicating both a common source of nitrate and ${ }^{99} \mathrm{Tc}$ (the S-3 Site) and migration along common flowpaths (Figure 4). Increased gross alpha activity in the groundwater downstream of the NT-3 catchment reflects inputs of uranium isotopes from sources in the Boneyard/Burnyard/HCDA. 
Most trace metal contamination in the Maynardville Limestone occurs in the shallow groundwater near the S-3 Site and the Boneyard/Burnyard/HCDA. Near the S-3 Site, the principal trace metal contaminants are barium, boron, cadmium, copper, lead, mercury, strontium, and uranium. Some of these metals (e.g., cadmium) were entrained in the highly acidic wastes disposed at the site, and others (e.g., strontium) were dissolved from the underlying bedrock. Trace metal contamination is sporadic in the groundwater at the Boneyard/Burnyard/HCDA, and the principal contaminants are beryllium, manganese, mercury, nickel, and uranium. Boron and uranium are the most common trace metal contaminants in the Aquifer downgradient of the S-3 Site and the Boneyard/Burnyard/ HCDA, which indicates that relatively mobile, ionic species of both metals are present in the groundwater.

\subsection{Surface Water Contamination}

Many of the principal components of the groundwater contaminant plumes in the Bear Creek Regime, including nitrate, ${ }^{99} \mathrm{Tc}$, uranium isotopes, several trace metals, and a few VOCs (PCE, TCE, and cis-1,2-DCE), occur in upper Bear Creek (i.e., upstream of BCK-09.40) and several of its northern tributaries. However, the quality of surface water in Bear Creek improved dramatically after waste disposal at the S-3 Site ceased in 1983. Nitrate concentrations in upper Bear Creek at BCK-12.46, for example, exceeded 1,000 mg/L in 1983, but were less than $200 \mathrm{mg} / \mathrm{L}$ in 1994. Currently, input from several northern tributaries (primarily NT-1, NT-2, NT-3, and NT-8) during seasonally high flow conditions contribute the bulk of the contamination to the creek. During dry periods, contaminant flux into Bear Creek is generally lower, but because of less dilution in the creek channel, concentrations are typically higher and are probably controlled by contaminant levels in the groundwater discharged from springs SS-1, SS-4, and SS-5 (DOE 1997). 


\subsection{MONITORING DATA EVALUATION}

The following sections provide an evaluation of the monitoring data for the network of CY 1998 sampling locations in the Bear Creek Regime, as reported in the annual Groundwater Monitoring Report (GWMR) issued by the Lockheed Martin Energy Systems, Inc. Y-12 Plant GWPP in March 1999 (AJA Technical Services, Inc. 1999). The discussion mirrors the applicable requirements of DOE Order 5400.1A. Section 3.1 contains an evaluation of groundwater quality in areas that are, or could be, affected by Y-12 Plant operations (hereafter referenced as Surveillance Monitoring). Section 3.2 contains an evaluation of surface water and groundwater quality where contaminants are most likely to migrate beyond the ORR boundaries (hereafter referenced as Exit Pathway/Perimeter Monitoring), and increasing long-term contaminant trends are described in Section 3.3. Each evaluation is based on historical and CY 1998 results that meet the applicable data quality objectives (DQOs) defined in Y-12 Plant Groundwater Protection Program - Groundwater Monitoring Program Data Management Plan (Martin Marietta Energy Systems, Inc. 1993). Detailed descriptions of the DQO criteria and associated data screening process, along with summaries of the CY 1998 data that do not meet applicable DQOs, are provided in Section 2.6 of the CY 1998 GWMR.

\subsection{Surveillance Monitoring}

The CY 1998 monitoring results reported for the following 27 monitoring wells were evaluated for the purposes of DOE Order 5400.1A Surveillance Monitoring in the Bear Creek Regime.

\begin{tabular}{|c|c|c|c|c|c|}
\hline \multicolumn{6}{|c|}{ CY 1998 Surveillance Monitoring Well Network } \\
\hline \multicolumn{3}{|c|}{ Aquitard Wells } & \multicolumn{3}{|c|}{ Aquifer Wells } \\
\hline Well Number & Monitored & $\begin{array}{l}\text { Interval Depth } \\
\text { (t) bgs) }\end{array}$ & Well Number & $\begin{array}{r}\text { Monitored } \\
\text { (f }\end{array}$ & $\begin{array}{l}\text { nterval Depth } \\
\text { bgs) }\end{array}$ \\
\hline $\begin{array}{l}\text { GW-008 } \\
\text { GW-046 } \\
\text { GW-085 } \\
\text { GW-115 } \\
\text { GW-276 } \\
\text { GW-287 } \\
\text { GW-537 } \\
\text { GW-627 } \\
\text { GW-653 } \\
\text { GW-829 }\end{array}$ & $\begin{array}{r}13.0 \\
5.0 \\
48.4 \\
37.6 \\
11.3 \\
5.6 \\
4.8 \\
254.0 \\
26.3 \\
102.9\end{array}$ & $\begin{array}{lc}- & 25.5 \\
- & 20.3 \\
- & 58.8 \\
- & 53.0 \\
- & 18.5 \\
- & 12.5 \\
- & 23.3 \\
- & 270.0 \\
- & 39.0 \\
- & 114.6\end{array}$ & $\begin{array}{l}\text { GW-053 } \\
\text { GW-056 } \\
\text { GW-226 } \\
\text { GW-311 } \\
\text { GW-315 } \\
\text { GW-621 } \\
\text { GW-683 } \\
\text { GW-684 } \\
\text { GW-685 } \\
\text { GW-695 } \\
\text { GW-703 } \\
\text { GW-704 } \\
\text { GW-706 } \\
\text { GW-724 } \\
\text { GW-725 } \\
\text { GW-738 } \\
\text { GW-740 }\end{array}$ & $\begin{array}{r}11.4 \\
49.1 \\
45.0 \\
25.6 \\
90.0 \\
23.3 \\
133.9 \\
106.4 \\
88.5 \\
50.6 \\
135.0 \\
246.0 \\
157.0 \\
289.6 \\
132.5 \\
63.5 \\
165.6\end{array}$ & $\begin{array}{lr}- & 32.8 \\
- & 55.2 \\
- & 55.0 \\
- & 40.3 \\
- & 104.0 \\
- & 40.5 \\
- & 196.8 \\
- & 128.4 \\
- & 138.3 \\
- & 62.6 \\
- & 182.0 \\
- & 256.0 \\
- & 182.5 \\
- & 301.6 \\
- & 142.5 \\
- & 88.0 \\
- & 190.0\end{array}$ \\
\hline
\end{tabular}


As shown in the preceding summary, 10 of these wells are completed in Aquitard (Nolichucky Shale or Maryville Limestone), including two wells located hydraulically upgradient (GW-115) and downgradient (GW-276) of the S-3 Site; three wells (GW-085, GW-537, and GW-829) located along geologic strike between the S-3 Site and the Oil Landfarm WMA; one well (GW-008) located near the west end of the Oil Landfarm; and four wells (GW-046, GW-287, GW-627, and GW-653) located downgradient of the BCBG WMA (Figure 6). The remaining 17 wells are completed in the Aquifer (Maynardville Limestone or Knox Group), including one well (GW-311) located downgradient of the Rust Spoil Area; one well (GW-315) located downgradient of Spoil Area I, one well located along the southwestern boundary of the Oil Landfarm WMA (GW-226); one well located directly south of BG-A South (GW-053), and 13 wells that compose three of the four Maynardville Limestone Exit Pathway Pickets in the Bear Creek Regime: Picket A (GW-056, GW-683, GW-684, and GW-685) located about 2,000 ft west of the BCBG WMA; Picket B (GW-621, GW-695, GW-703, GW-704, and GW-706) located about 1,000 ft southwest of the Oil Landfarm WMA; and Picket C (GW-724, GW-725, GW-738, and GW-740) located about 3,000 ft southwest of the S-3 Site (Figure 6). Wells at each Exit Pathway Picket are completed at various depths within different hydrostratigraphic zones along a strike-normal transect across the Maynardville Limestone and lower Knox Group (Figure 7).

All of the wells listed above were sampled twice (semiannually) during CY 1998 (Table 2), once during the first quarter of the year (seasonally high groundwater flow) and once during the third quarter of the year (seasonally low groundwater flow). Samples were collected from each well in accordance with the Y-12 Plant GWPP technical procedure (SESD-TP-8204 Rev.3) for low-flow minimal drawdown sampling (hereafter referenced as low-flow sampling). Under this method, groundwater samples (including duplicates) are collected immediately after field measurements (pH, conductivity, temperature, oxidation-reduction potential [REDOX], and dissolved oxygen) show stable values (minimal variation over four consecutive readings) in the groundwater purged from the well at a rate low enough ( $<300$ milliliters per minute) to ensure minimal drawdown of the water level in the well ( $<0.1 \mathrm{ft}$ per quarter-hour). Low-flow sampling differs from the sampling method used by the Y-12 Plant GWPP before October 1997, which involved purging at least three well volumes (if the well did not purge dry) at a much higher pumping rate (1.0 to 1.8 gallons per minute) before collecting samples from each well (hereafter referenced as conventional sampling).

Groundwater samples from each well were analyzed for inorganics (major ions and trace metals), VOCs, and selected radioanalytes (Table 3). Analytical results for each groundwater sample are presented in Appendix D of the CY 1998 GWMR.

Evaluation of the CY 1998 monitoring data for the purposes of Surveillance Monitoring focused on the principal components of the groundwater contaminant plumes in the Bear Creek Regime: nitrate, trace metals (barium, boron, strontium, and uranium), VOCs (chloroethenes, chloroethanes, and chloromethanes), and radioactivity (gross alpha and gross beta). As shown in the following summary, one or more of these contaminants were detected in at least one of the groundwater samples collected during CY 1998 from all but one of the wells (S-3 Site background well GW-115) used for Surveillance Monitoring purposes in the Bear Creek Regime. 
Principal Contaminants in the CY 1998 Surveillance Monitoring Wells

\begin{tabular}{|c|c|c|c|c|c|c|c|c|c|c|}
\hline \multirow{3}{*}{$\begin{array}{c}\text { Well } \\
\text { Number }\end{array}$} & \multicolumn{10}{|c|}{ Contaminant Type } \\
\hline & \multicolumn{5}{|c|}{ Inorganics } & \multicolumn{3}{|c|}{ VOCs } & \multicolumn{2}{|c|}{ Radioactivity } \\
\hline & NO3 & $\mathbf{B a}$ & $\mathbf{B}$ & $\mathrm{Sr}$ & $\mathbf{U}$ & $\begin{array}{l}\text { Chloro- } \\
\text { ethenes }\end{array}$ & $\begin{array}{l}\text { Chloro- } \\
\text { ethanes }\end{array}$ & $\begin{array}{l}\text { Chloro- } \\
\text { methanes }\end{array}$ & $\begin{array}{l}\text { Gross } \\
\text { Alpha }\end{array}$ & $\begin{array}{c}\text { Gross } \\
\text { Beta }\end{array}$ \\
\hline GW-008 & . & . & . & . & . & - & - & . & . & $\bullet$ \\
\hline GW-046 & . & . & . & $\bullet$ & . & $\bullet$ & $\bullet$ & $\bullet$ & . & . \\
\hline GW-053 & . & . & $\bullet$ & . & . & - & $\bullet$ & . & . & . \\
\hline GW-056 & . & . & . & . & . & - & . & . & . & . \\
\hline GW-085 & $\bullet$ & . & . & . & . & . & . & . & . & $\bullet$ \\
\hline GW-115 & . & . & . & . & . & . & . & . & . & . \\
\hline GW-226 & $\bullet$ & . & . & . & $\bullet$ & $\bullet$ & $\bullet$ & $\bullet$ & - & $\bullet$ \\
\hline GW-276 & $\bullet$ & . & . & . & $\bullet$ & $\bullet$ & . & $\bullet$ & - & $\bullet$ \\
\hline GW-287 & . & . & . & . & . & $\bullet$ & . & . & . & . \\
\hline GW-311 & . & . & . & . & . & - & . & - & . & . \\
\hline GW-315 & - & . & . & . & . & - & . & . & . & $\bullet$ \\
\hline GW-537 & - & - & . & $\bullet$ & . & . & . & $\bullet$ & - & - \\
\hline GW-621 & . & . & . & . & - & $\bullet$ & . & . & . & . \\
\hline GW-627 & - & . & . & . & . & - & $\bullet$ & . & . & . \\
\hline GW-653 & . & . & . & . & . & $\bullet$ & $\bullet$ & . & . & . \\
\hline GW-683 & - & . & . & . & $\bullet$ & . & . & . & - & $\bullet$ \\
\hline GW-684 & - & . & . & . & $\bullet$ & . & . & . & - & - \\
\hline GW-685 & . & . & . & . & . & . & . & ". & - & . \\
\hline GW-695 & - & . & . & . & . & - & . & . & . & - \\
\hline GW-703 & $\bullet$ & . & . & . & . & - & . & . & - & - \\
\hline GW-704 & - & . & . & . & . & - & - & - & . & - \\
\hline GW-706 & - & . & . & . & - & - & . & . & - & - \\
\hline GW-724 & - & . & . & . & . & $\bullet$ & . & - & . & . \\
\hline GW-725 & $\bullet$ & . & . & . & . & - & . & - & $\bullet$ & $\bullet$ \\
\hline GW-738 & - & . & . & . & . & $\bullet$ & . & . & . & - \\
\hline GW-740 & - & . & . & . & . & • & - & - & . & - \\
\hline GW-829 & $\bullet$ & - & . & . & $\bullet$ & . & . & . & . & . \\
\hline
\end{tabular}

Results for these wells are generally consistent with respective historical data and reflect migration of contaminants from the S-3 Site, the Rust Spoil Area, the Oil Landfarm WMA (including the Boneyard/Burnyard/HCDA), the BCBG WMA, or a combination of these source areas. Respective CY 1998 monitoring results for nitrate, trace metals, VOCs, and radiological contaminants are discussed in the following sections.

\subsubsection{Nitrate}

As noted in Section 2.4.1, historical operation of the S-3 Site emplaced a relatively continuous plume of nitrate in the Aquitard that extends south toward the upper reach of Bear Creek and along strike in the water table interval and the deeper bedrock for more than $3,000 \mathrm{ft}$ to the west, and in the Aquifer from south of the S-3 Site for about $10,000 \mathrm{ft}$ along strike to the west in the deeper bedrock (Figure 5). Monitoring results for the network of wells used for Surveillance Monitoring purposes 
during CY 1998 reflect this widespread nitrate contamination and, as shown in the following summary, indicate that nitrate levels in the Aquitard remain above $100 \mathrm{mg} / \mathrm{L}$ in the shallow groundwater to the south (GW-276) and west (GW-537) of the S-3 Site and exceed the $10 \mathrm{mg} / \mathrm{L}$ maximum contaminant level (MCL) in Aquifer wells approximately 7,000 ft west of the S-3 Site (GW-703, GW-704, and GW-706).

Summary of Nitrate Results for Surveillance Monitoring Wells

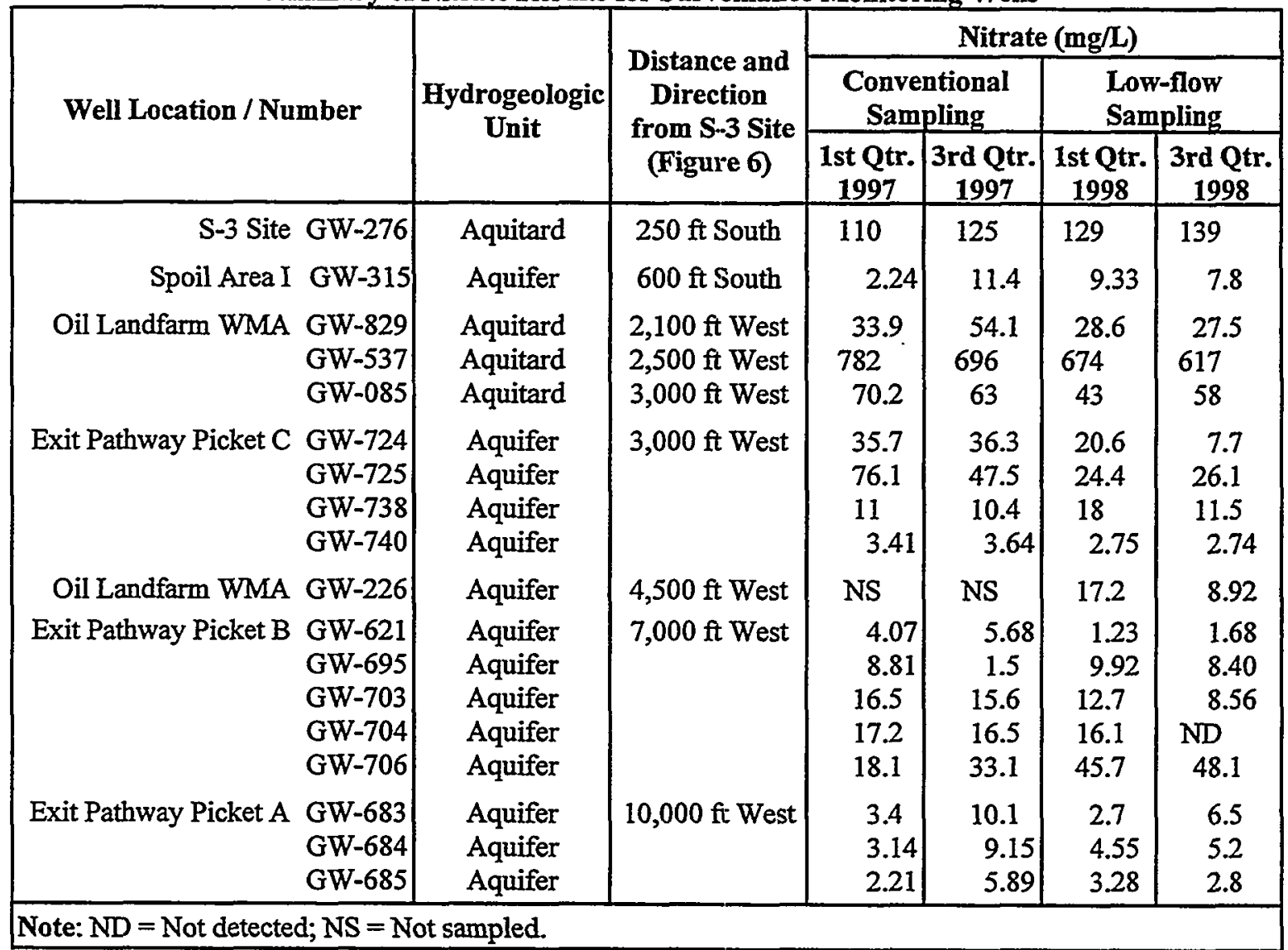

The following discussion of these CY 1998 results is primarily focused on the Aquitard and Aquifer wells with nitrate concentrations that exceed the MCL.

Historical data show that Aquitard well GW-276 yields moderately contaminated, calciummagnesium-bicarbonate groundwater (Figure 8) from the water table interval in the Aquitard (Nolichucky Shale) about $250 \mathrm{ft}$ directly south (across geologic strike) of the S-3 Site. Although the CY 1998 monitoring data show that nitrate levels in the well remain above $100 \mathrm{mg} / \mathrm{L}$, these results reflect the decreased (more than an order of magnitude) concentrations produced from a combination of substantially reduced nitrate flux (and other contaminants) following closing/capping the S-3 Site and flushing of contaminated shallow groundwater during subsequent seasonal and episodic recharge/discharge cycles (Shevenell 1994). Moreover, the CY 1998 (low-flow sampling) nitrate results are consistent with historical (conventional sampling) data indicating that rate of concentration decrease has slowed since the mid-1990s, as illustrated by the nitrate concentrations obtained in March 1988 (1,217 mg/L), March 1994 (147 mg/L), and March 1998 (129 mg/L), which 
suggests that the most highly contaminated groundwater in the more permeable flowpaths has been flushed from the shallow groundwater system in the Aquitard near the S-3 Site. Additionally, the above data summary shows that the nitrate results obtained using the low-flow sampling method in CY 1998 do not differ significantly from the nitrate results obtained using the conventional sampling method in CY 1997.

Historical data show that Aquitard well GW-829 yields moderately contaminated sodiumbicarbonate groundwater (Figure 8) from the shallow bedrock interval in the Nolichucky Shale about $1,800 \mathrm{ft}$ west (along geologic strike) of the S-3 Site. As shown in the preceding data summary, the CY 1998 monitoring results indicate that nitrate levels in the well remain above the MCL $(10 \mathrm{mg} / \mathrm{L})$ but are significantly lower (15\% to 50\%) than nitrate levels evident during CY 1997. Moreover, the CY 1998 nitrate values represent the lowest concentrations ever reported for the well, which has been sampled on a semiannual basis since August 1995. Although historical (conventional sampling) nitrate data show a generally decreasing trend (Figure 9), the relatively sharp concentration decrease indicated by the CY 1998 (low-flow sampling) results may be an artifact of the groundwater sampling protocol. Higher nitrate levels in samples collected using the conventional sampling method may be evident because the hydrologic response to purging the well may increase the flux of nitrate (and other contaminants) into the well and consequently "inflate" the nitrate concentrations compared to those obtained from low-flow sampling.

As shown in the preceding data summary, the CY 1998 nitrate concentrations reported for well Aquitard GW-537, which totally dominate the principal ion chemistry of the samples from the well (Figure 8), exceed $600 \mathrm{mg} / \mathrm{L}$. This well is completed in the water table interval ( $23 \mathrm{ft} \mathrm{bgs}$ ) in the Nolichucky Shale about 2,500 ft west (along geologic strike) of the S-3 Site. The very high nitrate levels evident in well GW-537 are believed to be maintained primarily via upward inflow of nitrate (and other similarly mobile components of the S-3 Site contaminant plume) from the deeper flow system because, as noted in the previous discussion of monitoring results for well GW-276, seasonal and episodic recharge/discharge cycles have flushed the most highly contaminated groundwater from the shallow flow system in the Aquitard. Assuming that the center of mass of the nitrate plume in the Aquitard is slowly migrating westward (along strike), upwelling of nitrate from the deeper bedrock should produce relatively stable or increasing long-term concentration trends in the shallow groundwater near well GW-537 (DOE 1997). Excluding the conspicuously low nitrate concentration in September 1994 ( $81 \mathrm{mg} / \mathrm{L}$ ), historical (conventional sampling) data obtained since January 1990 show variable but relatively stable long-term nitrate levels (Figure 9), with a generally decreasing trend evident between February $1994(1,127 \mathrm{mg} / \mathrm{L})$ and August $1998(617 \mathrm{mg} / \mathrm{L})$.

Nitrate also dominates the ion chemistry of the groundwater samples collected from Aquitard well GW-085 during CY 1998 (Figure 8). Elevated nitrate concentrations in the calcium-magnesiumbicarbonate groundwater at this well, which is completed at a depth of $55.2 \mathrm{ft} \mathrm{bgs}$ in the Nolichucky Shale about 3,000 ft west of the S-3 Site, reflect strike parallel migration of the nitrate plume in the shallow bedrock west of NT-2 and indicate that the leading edge of the plume lies west of the well toward NT-3 (DOE 1997). Historical (conventional sampling) data for well GW-085 show that nitrate levels generally increased between May $1991(115 \mathrm{mg} / \mathrm{L})$ and October $1993(312.6 \mathrm{mg} / \mathrm{L})$ then subsequently decreased below $100 \mathrm{mg} / \mathrm{L}$ through September $1997(63 \mathrm{mg} / \mathrm{L})$. The nitrate concentrations in the groundwater samples collected from the well in March $1998(43 \mathrm{mg} / \mathrm{L})$ and 
August $1998(58 \mathrm{mg} / \mathrm{L})$, which reflect the lowest levels ever reported for the well, continue this decreasing concentration trend (Figure 9). The long-term concentration trend for well GW-085 suggest westward, strike parallel migration of a "pulse" of nitrate in the shallow flow system in the Aquitard west of the S-3 Site.

Nitrate concentrations reported for the groundwater samples collected from Aquifer well GW-226 are substantially higher than historical (conventional sampling) data for the well (see Section 3.3). This shallow bedrock well is completed at a depth of $55 \mathrm{ft}$ bgs and yields (nitrate-enriched) calciummagnesium-bicarbonate groundwater (Figure 10) from the highly permeable basal portion (Zone 2) of the Maynardville Limestone south of Sanitary Landfill I about 4,500 ft west of the S-3 Site (Figure 6). Elevated nitrate levels in the groundwater at this well probably reflect inflow of nitrate (and other mobile groundwater contaminants) into the Maynardville Limestone along a major losing reach of Bear Creek south of Sanitary Landfill I. Additionally, seasonally variable flux of nitrate (and other contaminants) along the groundwater flowpaths intercepted by Aquifer well GW-226 is suggested by the much higher concentration $(17.2 \mathrm{mg} / \mathrm{L})$ and groundwater elevation $(933.47 \mathrm{ft} \mathrm{msl})$ evident in March 1998 (seasonally high flow) compared with the lower nitrate levels $(8.92 \mathrm{mg} / \mathrm{L}$ ) and groundwater elevation ( $923.57 \mathrm{ft} \mathrm{msl}$ ) evident during September 1998 (seasonally low flow).

Most of the Aquifer wells comprising Exit Pathway pickets A, B, and C yield calcium-magnesiumbicarbonate groundwater (Figure 10). Distinctive proportions of magnesium characterize the groundwater in many of these wells. Magnesium proportions below $30 \%$ of total cations are generally characteristic of shallow groundwater inflow from the Aquitard (e.g., GW-056) and proportions above 30\% indicative of groundwater inflow from the Copper Ridge Dolomite (e.g., GW-740). Additionally, some of the wells (e.g., GW-704) yield sulfate-enriched groundwater (about $10 \%$ of total anions) resulting from dissolution of locally disseminated gypsum and anhydrite (Saunders and Toran 1992). Also, several Aquifer wells completed in the shallow karst network along Bear Creek Road (e.g., GW-056 and GW-685) have higher proportions ( $>10 \%)$ of sodium and chloride than typical of most Aquifer wells and may reflect the use of road salt during the winter months. Aside from groundwater with locally elevated sodium, chloride, or sulfate concentrations, the plume of nitrate originating from the S-3 Site is the principal source of variation from the typical ion chemistry of groundwater in the Aquifer wells at Exit Pathway Pickets A, B, and C.

As shown in the preceding nitrate data summary, the low-flow sampling results obtained during CY 1998 for most of the Aquifer wells that compose Exit Pathway Pickets A, B, and C are generally consistent with respective conventional sampling results obtained during CY 1997. However, results for wells GW-724 and GW-725 at Picket C and well GW-621 at Picket B show a fairly sharp concentration decrease from the CY 1997 sampling results. Conversely, the CY 1998 results for well GW-706 at Picket B show substantially higher nitrate concentrations than in CY 1997 and support an increasing long-term concentration trend that began in CY 1993 (see Section 3.3). The low-flow sampling results for these wells may be representative of flowpaths within a small radius of the well whereas the conventional sampling results are probably representative of a larger zone of influence.

The low-flow sampling results for the wells in Exit Pathway Pickets A, B, and C are generally consistent with historical (conventional sampling) nitrate data with respect to the seasonal and 
episodic dilution-related and flux-related concentration fluctuations that are characteristic of the nitrate plume in the Aquifer (DOE 1997). For example, nitrate levels in some wells (e.g., GW-683) are usually highest during seasonally low flow (summer and fall), which reflects less dilution from uncontaminated recharge, whereas nitrate levels in other wells (e.g., GW-725) are usually highest during seasonally high flow (winter and spring), which suggests greater advective flux of nitrate.

Based on aggregate average nitrate concentrations determined from low-flow and conventional sampling data, nitrate levels appear to have generally decreased at Exit Pathway Picket $C$, remained relatively stable at Picket $B$, and generally decreased at Picket A (Figure 11). Slowly decreasing nitrate concentrations in the groundwater at Exit Pathway Picket $\mathrm{C}$ and Exit Pathway Picket $\mathrm{A}$ probably reflect the long-term effects of reduced contaminant flux and greater attenuation (i.e., dilution) following closure of the S-3 Site. Discharge of nitrate-contaminated groundwater and surface water from the NT-1 and NT-2 catchments and inflow along the losing reach of Bear Creek south of Sanitary Landfill I probably helps maintain the nitrate levels in the groundwater at Exit Pathway Picket B. The average CY 1998 nitrate concentrations are, for the first time, higher at Exit Pathway Picket B than at Picket C.

\subsubsection{Trace Metals}

The following evaluation of the CY 1998 monitoring results for barium, boron, strontium, and uranium is focused on the total (unfiltered sample) concentrations that exceed the applicable upper tolerance limit (UTL) reported in Determination of Reference Concentrations for Inorganic Analytes in Groundwater at the Department of Energy Y-12 Plant, Oak Ridge, Tennessee (HSW Environmental Consultants, Inc. et al. 1995). The UTLs for these metals, summarized below, were determined from statistical analysis of historical (CY 1986 - CY 1993) data for specific groups of wells (i.e., clusters) differentiated by similar geochemical characteristics.

UTLs for Barium, Boron, Strontium, and Uranium

\begin{tabular}{|r|c|c|c|c|c|c|}
\hline \multirow{2}{*}{$\begin{array}{c}\text { Trace } \\
\text { Metal }\end{array}$} & \multicolumn{6}{|c|}{ UTL (mg/L) } \\
\cline { 2 - 7 } & Cluster 1 & Cluster 2 & Cluster 3 & Cluster 4 & Cluster 6 & Cluster 10 \\
\hline Barium & 0.71 & 0.68 & 0.79 & 0.34 & 0.34 & 0.35 \\
Boron & 0.12 & 0.028 & 0.041 & 0.028 & 3.1 & 3.1 \\
Strontium & 4.4 & 0.079 & 0.92 & 0.079 & 0.92 & 0.92 \\
Uranium & 0.012 & 0.004 & 0.005 & 0.005 & 0.004 & 0.005 \\
\hline
\end{tabular}

Cluster 1 is characterized by shallow (i.e., $<100 \mathrm{ft} \mathrm{bgs)} \mathrm{wells} \mathrm{in} \mathrm{the} \mathrm{Maynardville} \mathrm{Limestone} \mathrm{and}$ Nolichucky Shale. Cluster 2 is characterized by shallow wells that monitor low TDS groundwater in the Aquitard formations (primarily the Maryville Limestone and Nolichucky Shale). Cluster 3 is characterized by shallow wells in Maryville Limestone and Nolichucky Shale. Cluster 4 is characterized by wells in the Knox Group (primarily the Copper Ridge Dolomite). Cluster 6 is characterized by wells that monitor sodium-chloride-bicarbonate groundwater at depth ( $>400 \mathrm{ft}$ bgs) in the Nolichucky Shale, and Cluster 10 is characterized primarily by wells that monitor the sodiumbicarbonate groundwater that is typically encountered below the first transitional hydraulic 
conductivity decrease in the Aquitard (see Section 2.3.1). The UTL for each metal represents the maximum concentration expected in the groundwater monitored by the wells that compose each cluster, and results that exceed the UTL (i.e., elevated concentrations) may be considered as potential evidence of groundwater contamination (HSW Environmental Consultants, Inc. et al. 1995).

As shown in the following data summary, total concentrations of barium, boron, strontium, or uranium that exceed respective UTLs were reported for unfiltered groundwater samples from four of the Aquitard wells and five of the Aquifer wells used for Surveillance Monitoring during CY 1998.

Summary of CY 1998 Barium, Boron, Strontium, and Uranium Results for Surveillance Monitoring Wells

\begin{tabular}{|c|c|c|c|c|c|c|c|c|c|}
\hline \multirow{3}{*}{$\begin{array}{l}\text { Well } \\
\text { Number }\end{array}$} & \multirow{3}{*}{$\begin{array}{l}\text { UTL } \\
\text { Well } \\
\text { Cluster }\end{array}$} & \multicolumn{8}{|c|}{ Total Concentration (mg/L) } \\
\hline & & \multicolumn{2}{|c|}{ Barium } & \multicolumn{2}{|c|}{ Boron } & \multicolumn{2}{|c|}{ Strontium } & \multicolumn{2}{|c|}{ Uranium } \\
\hline & & $\begin{array}{c}\text { 1st Qtr. } \\
1998 \\
\end{array}$ & $\begin{array}{c}\text { 3rd Qtr. } \\
1998 \\
\end{array}$ & \begin{tabular}{|c|} 
1st Qtr. \\
1998 \\
\end{tabular} & $\begin{array}{c}\text { 3rd Qtr. } \\
1998\end{array}$ & $\begin{array}{c}\text { 1st Qtr. } \\
1998 \\
\end{array}$ & $\begin{array}{c}\text { 3rd Qtr. } \\
1998 \\
\end{array}$ & $\begin{array}{c}\text { 1st Qtr. } \\
1998 \\
\end{array}$ & $\begin{array}{c}\text { 3rd Qtr. } \\
1998\end{array}$ \\
\hline Aquitard Wells: & & & & & & & & & \\
\hline GW-046 & 2 & $<$ & $<$ & 0.038 & $<$ & 0.08 & 0.126 & $<$ & $<$ \\
\hline GW-276 & 3 & $<$ & $<$ & $<$ & $<$ & $<$ & $<$ & 0.63 & 0.726 \\
\hline GW-537 & 3 & 2.3 & 1.93 & $<$ & $<$ & 2.7 & 2.29 & $<$ & $<$ \\
\hline GW-829 & 10 & 0.56 & 0.496 & $<$ & $<$ & 1.1 & 0.959 & $<$ & $<$ \\
\hline Aquifer Wells: & & & & & & & & & \\
\hline GW-053 & 1 & $<$ & $<$ & 0.26 & 0.312 & $<$ & $<$ & $<$ & $<$ \\
\hline GW-226 & 1 & $<$ & $<$ & $<$ & $<$ & 0.016 & $<$ & $<$ & $<$ \\
\hline$G W-683$ & 3 & $<$ & $<$ & $<$ & $<$ & 0.085 & 0.13 & 0.023 & 0.0339 \\
\hline GW-684 & 3 & $<$ & $<$ & $<$ & $<$ & $<$ & $<$ & 0.027 & 0.0331 \\
\hline GW-706 & 10 & $<$ & $<$ & $<$ & $<$ & $<$ & $<$ & 0.13 & 0.111 \\
\hline
\end{tabular}

Historical (conventional sampling) data for well GW-276 show that the concentrations of barium, boron, strontium, and uranium (as well as other trace metals) decreased substantially after the S-3 Ponds were closed and capped in 1988. The CY 1998 (low-flow sampling) results indicate that barium, boron, and strontium levels remain below the applicable UTL $(0.79 \mathrm{mg} / \mathrm{L}, 0.041 \mathrm{mg} / \mathrm{L}$, and $0.92 \mathrm{mg} / \mathrm{L}$, respectively), whereas uranium concentrations are more than an order of magnitude above the UTL $(0.005 \mathrm{mg} / \mathrm{L})$ and exceed the proposed MCL for uranium $(0.02 \mathrm{mg} / \mathrm{L})$. Differential retardation in the subsurface probably explains why uranium concentrations remain much more elevated relative to barium, boron, and strontium; uranium levels have decreased at a slower rate because uranium is more readily adsorbed to mineral surfaces, and the elevated concentrations have been maintained by this subsurface reservoir of adsorbed uranium (DOE 1997).

Assuming a migration pattern similar to that of nitrate from the S-3 Site, elevated barium and strontium concentrations in the shallow groundwater at Aquitard wells GW-085, GW-537, and GW-829 reflect strike-parallel transport from the S-3 Site and upward migration from the deeper bedrock east of NT-1 into the shallow bedrock west of the tributary (DOE 1997). Barium and strontium results for well GW-829 suggest decreasing trends following installation of the well in June 1995 (Figure 12). In contrast, results for wells GW-085 and GW-537 show that the concentrations of both metals concurrently increased until February 1994 and concurrently decreased 
thereafter (Figure 12). The long-term concentration trends for wells GW-085 and GW-537 suggest westward, strike-parallel migration of a "pulse" of barium and strontium in the shallow flow system in the Aquitard west of the S-3 Site. This "pulse" may reflect a delayed response to denitrification and closure of the S-3 Pond.

Elevated total boron concentrations reported for the groundwater samples from Aquifer well GW-053 probably reflect influx of boron-contaminated groundwater/surface water from one or more source areas within the BCBG WMA, which received substantial volumes of borax (hydrated sodium borate) waste water from the Y-12 Plant. Elevated boron concentrations reported for several Aquitard monitoring wells that were not sampled during CY 1998 indicate groundwater transport toward the tributaries of Bear Creek (NT-6, NT-7, and NT-8) that traverse the site (AJA Technical Services, Inc. 1997). Well GW-053 is located north of Bear Creek, about 1,200 ft downstream of the confluence with NT-6 and about $200 \mathrm{ft}$ upstream of the confluence with NT-7 (Figure 6).

The Boneyard/Burnyard/HCDA is believed to be a primary source of elemental uranium (and gross alpha activity) in the Aquifer to the south and west of the Oil Landfarm WMA (see Section 2.4.2). Uranium leached from the source(s) at this site, which may lie within the saturated zone during seasonally high flow conditions, recharges directly into the Maynardville Limestone or migrates westward (along geologic strike) in the Aquitard toward NT-3 and enters the Aquifer along the major losing reach of the Bear Creek south of the Sanitary Landfill I (DOE 1997). This migration pattern is consistent with the elevated uranium concentrations reported for the unfiltered $(0.016 \mathrm{mg} / \mathrm{L})$ and filtered $(0.015 \mathrm{mg} / \mathrm{L}$ ) samples collected from Aquifer well GW-226 in March 1998 (seasonally high flow conditions). Substantially lower total $(0.0091 \mathrm{mg} / \mathrm{L})$ and dissolved $(0.0079 \mathrm{mg} / \mathrm{L})$ uranium levels evident in the well during September 1998 (seasonally low flow conditions) suggest seasonally variable flux of uranium from the Boneyard/Burnyard/HCDA. Historical (conventional sampling) data show that uranium concentrations in well GW-226 steadily increased from less than the applicable UTL $(0.012 \mathrm{mg} / \mathrm{L})$ in July $1988(0.004 \mathrm{mg} / \mathrm{L})$ to a peak concentration of $0.092 \mathrm{mg} / \mathrm{L}$ in October 1990 (Figure 13); the CY 1998 uranium results suggest a subsequently decreasing long-term concentration trend.

As shown in the preceding summary of CY 1998 trace metal data, the total uranium concentrations reported for Exit Pathway Picket B well GW-706 are the highest concentrations reported for any of the Aquifer wells sampled during CY 1998. These results show that total uranium concentrations remain above the proposed MCL $(0.02 \mathrm{mg} / \mathrm{L})$ and are consistent with historical (conventional sampling) data indicating a relatively stable long-term concentration trend (Figure 13). Elevated uranium levels in the groundwater at well GW-706 probably reflect migration from Boneyard/Burnyard/HCDA (DOE 1997); Exit Pathway Picket B is located west (downgradient) of the NT-3 confluence with Bear Creek and the losing reach of Bear Creek south of Sanitary Landfill I.

Elevated total (and dissolved) uranium levels indicated by the CY 1998 monitoring results for Aquifer wells GW-683 and GW-684 (Exit Pathway Picket A), which range from $0.0343 \mathrm{mg} / \mathrm{L}$ in well GW-683 (August 1998) to $0.028 \mathrm{mg} / \mathrm{L}$ in well GW-684 (March 1998), slightly exceed the proposed MCL for uranium $(0.02 \mathrm{mg} / \mathrm{L})$ and reflect the slowly decreasing long-term concentration trend indicated by historical (conventional sampling) data for each well (Figure 13). Elevated uranium concentrations in the groundwater at these wells probably reflect downgradient, strike- 
parallel transport of uranium from the Boneyard/Burnyard/HCDA, but may also be at least partially attributed to inflow of radiologically contaminated groundwater/surface water from the three Bear Creek tributaries that drain the BCBG WMA (DOE 1997).

\subsubsection{Volatile Organic Compounds}

Excluding false-positive results, one or more chloroethenes (PCE, TCE, cis-1,2-DCE, trans-1,2-DCE, 1,1-DCE, and VC), chloromethanes (carbon tetrachloride, chloroform, and methylene chloride), chloroethanes (1,1,1-TCA, 1,2-DCA, 1,1-DCA, and chloroethane), petroleum hydrocarbons (benzene and dimethylbenzene), or miscellaneous common laboratory reagents (e.g., acetone and 2-butanone) were detected in at least one groundwater sample collected during CY 1998 from six Aquitard wells and 13 Aquifer wells used for Surveillance Monitoring purposes in the Bear Creek Regime (Table 4). Maximum summed VOC concentrations are less than $10 \mu \mathrm{g} / \mathrm{L}$ in wells GW-056, GW-287, GW-537, and GW-695; range between 10 and $100 \mu \mathrm{g} / \mathrm{L}$ in wells GW-008, GW-053, GW-276, GW-311, GW-315, GW-653, GW-703, GW-704, GW-706, GW-725, GW-738, and GW-740; range between 100 and $500 \mu \mathrm{g} / \mathrm{L}$ in wells GW-226, GW-627, and GW-724; and exceed 15,000 $\mu \mathrm{g} / \mathrm{L}$ in well GW-046 (Table 4). As shown in the following summary, the maximum concentrations of PCE, TCE, cis-1,2-DCE, 1,1-DCE, VC, 1,2-DCA, and benzene exceed respective MCLs.

CX 1998 Maximum VOC Concentrations That Exceed MCLs

\begin{tabular}{|c|c|c|c|c|c|c|c|}
\hline \multirow{2}{*}{$\begin{array}{c}\text { Well } \\
\text { Number }\end{array}$} & \multicolumn{7}{|c|}{ Concentration $(\mu \mathrm{g} / \mathrm{L})$} \\
\hline & PCE & TCE & $\begin{array}{c}\text { cis-1,2- } \\
\text { DCE }\end{array}$ & 1,1-IDCE & VC & 1,2-DCA & Benzene \\
\hline Aquitard & & & & & & & \\
\hline GW-008 & 19 & (4) & 17 & 5 & $<10$ & $<5$ & $<5$ \\
\hline GW-046 & 4,600 & $\mathbf{3 , 0 0 0}$ & 6,400 & 66 & 760 & 7 & 49 \\
\hline GW-276 & 12 & $<5$ & $<5$ & $<5$ & $<10$ & $<5$ & $<5$ \\
\hline GW-627 & 250 & 79 & 5 & 11 & 10 & $<5$ & $<5$ \\
\hline \multicolumn{8}{|l|}{ Aquifer } \\
\hline GW-053 & (2) & (3) & 15 & $<5$ & (5) & $<5$ & $<5$ \\
\hline GW-226 & $<5$ & 180 & 7 & (2) & $<10$ & $<5$ & $<5$ \\
\hline GW-311 & $<5$ & 10 & $<5$ & $<5$ & $<10$ & $<5$ & $<5$ \\
\hline GW-315 & 12 & 6 & 5 & $<5$ & $<10$ & $<5$ & $<5$ \\
\hline GW-695 & $<5$ & 7 & (2) & $<5$ & $<10$ & $<5$ & $<5$ \\
\hline GW-703 & $<5$ & 21 & (4) & (2) & $<10$ & $<5$ & $<5$ \\
\hline GW-704 & $<5$ & 78 & (4) & 8 & $<10$ & $<5$ & $<5$ \\
\hline GW-706 & $<5$ & 12 & 8 & $<5$ & $<10$ & $<5$ & $<5$ \\
\hline GW-724 & (3) & 130 & (4) & $<5$ & $<10$ & $<5$ & $<5$ \\
\hline GW-725 & (3) & 42 & (4) & $<5$ & $<10$ & $<5$ & $<5$ \\
\hline GW-738 & $<5$ & 37 & (2) & $<5$ & $<10$ & $<5$ & $<5$ \\
\hline GW-740 & $<5$ & 72 & (3) & $<5$ & $<10$ & $<5$ & $<5$ \\
\hline MCL & 5 & 5 & 70 & 7 & 2 & 5 & 5 \\
\hline
\end{tabular}


The CY 1998 monitoring results for the Aquitard wells sampled during CY 1998 are generally consistent with historical (conventional sampling) data showing dissolved chloroethenes (primarily PCE, TCE, and cis-1,2-DCE) in the shallow groundwater south of the S-3 Site (GW-276) and southwest of the Oil Landfarm (GW-008) and in the shallow and deep groundwater south (GW-046) and west (GW-627 and GW-653) of BG-A South in the BCBG WMA.

Historical data for several Aquitard wells located adjacent to the S-3 Site show dissolved PCE concentrations above $5,000 \mu \mathrm{g} / \mathrm{L}$ in the shallow groundwater and indicate the presence of DNAPLs in the subsurface. However, the PCE results for the samples collected in January $(12 \mu \mathrm{g} / \mathrm{L})$ and July $(11 \mu \mathrm{g} / \mathrm{L}) 1998$ from Aquitard well GW-276, which is only $250 \mathrm{ft}$ south of the S-3 Site (Figure 6), illustrate the substantial attenuation of VOCs in the Aquitard. Both results exceed the MCL for PCE $(5 \mu \mathrm{g} / \mathrm{L})$ but are an order of magnitude lower than the levels reported for samples collected from the well in the late 1980 s (e.g., $230 \mu \mathrm{g} / \mathrm{L}$ in March 1988). Substantially decreased PCE concentrations mirror the trends evident for nitrate and trace metals, and likewise result from closing/capping the S-3 Site and subsequent flushing of the highly contaminated groundwater from the shallow flow system.

The CY 1998 monitoring results for Aquitard well GW-008, which was last sampled during the mid1980 s, confirm that this well monitors the plume of dissolved chloroethenes (PCE, TCE, cis-1,2-DCE, and 1,1-DCE) in the shallow groundwater southwest of the Oil Landfarm (see discussion in Section 2.4.2). The CY 1998 results for this well show that although the maximum PCE level $(19 \mu \mathrm{g} / \mathrm{L})$ exceeds the MCL, maximum summed VOC concentrations $(56 \mu \mathrm{g} / \mathrm{L})$ are an order of magnitude lower than evident during the mid-1980s $(>500 \mu \mathrm{g} / \mathrm{L})$. Decreased concentrations of dissolved VOCs in the shallow groundwater at well GW-008 are probably the result of several factors, including closure of the Oil Landfarm, installation of the low permeability cap over this site, and natural attenuation in the Aquitard. Seasonal and episodic recharge/discharge cycles also probably flush residual contamination from the shallow flow system. The unusually low TDS (57-67 mg/L) reported for the groundwater samples collected from the well during CY 1998, which suggests short residence time and implies active groundwater recharge and discharge flowpaths, support this interpretation. Additionally, the relatively large proportion of cis-1,2-DCE relative to PCE (and TCE) suggests that the decreased concentrations may at least partially reflect degradation. Under anaerobic conditions, reductive dechlorination of PCE occurs according to the following sequence (Hinchee et al. 1995):

$$
\mathrm{PCE} \rightarrow \mathrm{TCE}+\text { Chloride }(\mathrm{Cl}) \rightarrow \mathrm{DCE} \text { isomers }+2 \mathrm{Cl} \rightarrow \mathrm{VC}+3 \mathrm{Cl} \rightarrow \text { ethene }+4 \mathrm{Cl} \text {. }
$$

Several factors influence this process, including the availability of electron donors (e.g., hydrogen), and the efficiency of the process differs under methanogenic, sulfate-reducing, iron-reducing, and nitrate-reducing conditions (Chapelle 1996). The apparent lack of VC in the groundwater at well GW-008 suggests that the strongly reducing (methanogenic) conditions necessary to transform DCE isomers to VC either do not occur or that the VC is oxidized to carbon dioxide (Wilson et al. 1996). In either case, natural biodegradation probably at least partially explains the decreasing long-term VOC concentration trend indicated by historical data for well GW-008. 
Monitoring results obtained during CY 1998 show that Aquitard well GW-046 yields calciummagnesium-bicarbonate groundwater (Figure 10) containing a diverse mixture of dissolved chloroethenes, chloroethanes, chloromethanes, and petroleum hydrocarbons, with extremely high concentrations (i.e., > 1,000 $\mu \mathrm{g} / \mathrm{L}$ ) of several chloroethenes (e.g., PCE) indicating the presence of DNAPL in the subsurface. Additionally, the summed concentration of VOCs detected in the sample collected from the well in July $1998(15,260 \mu \mathrm{g} / \mathrm{L})$ is substantially higher compared to the sample collected from the well in January $1998(6,135 \mu \mathrm{g} / \mathrm{L})$. Assuming that these results are representative of VOC levels during seasonally wet (January 1998) and seasonally dry (July 1998) groundwater flow conditions, the large disparity between summed VOC concentrations suggests seasonally variable dilution from uncontaminated recharge rather than seasonally variable flux of VOCs in the shallow groundwater. Results for both samples also suggest natural biodegradation of PCE and 1,1,1-TCA, as indicated by the proportionally high concentrations of respective intermediate degradation compounds (cis-1,2-DCE and 1,1-DCA), the presence of respective biodegradation end products (VC and chloroethane), and the unusually high levels of chloride $(>20 \mathrm{mg} / \mathrm{L})$ in the groundwater at the well. Furthermore, the atypically low $\mathrm{pH}$ (field measurements $=4.39$ and 5.08) reported for well GW-046 may reflect chemical degradation of $1,1,1-\mathrm{TCA}$ whereby nearly $80 \%$ of the 1,1,1-TCA may be transformed to acetic acid (McCarty 1996).

Relatively low concentrations (1 - $23 \mu \mathrm{g} / \mathrm{L})$ of PCE, TCE, 1,1-DCE, cis-1,2-DCE, and 1,1-DCA were detected in at least one of the groundwater samples collected from Aquitard well GW-653 during CY 1998, with substantially higher summed concentrations evident during March 1998 $(29 \mu \mathrm{g} / \mathrm{L})$ than in September $1998(8 \mu \mathrm{g} / \mathrm{L})$. These low-flow sampling results for this well, which is completed at a depth of $39 \mathrm{ft} \mathrm{bgs} \mathrm{in} \mathrm{the} \mathrm{Nolichucky} \mathrm{Shale} \mathrm{about} 600 \mathrm{ft}$ west (along geologic strike) of BG-A South (Figure 6), are consistent with historical (conventional sampling) data. Results obtained from both sampling methods show: (1) lower levels of PCE relative to summed concentrations of potential PCE degradation products (cis-1,2-DCE, 1,1-DCE, and VC), and (2) seasonal concentration fluctuations, with higher summed VOC concentrations evident during seasonally high flow conditions (winter and spring) and lower concentrations evident during seasonally low flow conditions (summer and fall). Although dominated by these seasonal fluctuations, the CY 1998 and historical VOC data for well GW-653 indicate a slightly upward longterm concentration trend (see Section 3.3).

The CY 1998 VOC results for Aquitard well GW-627, which is completed at a depth of $270 \mathrm{ft}$ bgs in the Nolichucky Shale south (down-dip) of BG-A South (Figure 6), are consistent with historical data and show that this well yields calcium-magnesium-bicarbonate groundwater (Figure 8) containing dissolved chloroethenes (PCE, TCE, 1,1-DCE, cis-1,2-DCE, trans-1,2-DCE, and VC) and chloroethanes (1,1-DCA and chloroethane). The monitoring results also reflect the steadily increasing PCE and TCE concentration trends evident since February 1990 (see Section 3.3). The detection of these VOCs in well GW-627 generally coincides with the January 1990 discovery of PCE and TCE DNAPL in the Nolichucky Shale 260 to $330 \mathrm{ft}$ down dip of BG-A South (Haase and King 1990). The subsequent increasing concentration trend in well GW-627 clearly indicates migration of VOCs at depth in the Aquitard, although fate and transport modeling suggest it will take as long as 600 years for the PCE to migrate as far west as NT-8 (DOE 1997). 
The VOC results for the Aquifer wells used for Surveillance Monitoring purposes during CY 1998 (Table 4) are consistent with respective historical data and do not indicate any significant changes in the extent or distribution of dissolved VOCs in the Aquifer. As noted in Section 2.4.4, a discontinuous plume of dissolved VOCs (primarily TCE) occurs in the shallow karst network and the deeper bedrock in the Maynardville Limestone; the extent of the plume suggests a migration pattern similar to that of nitrate in the Maynardville Limestone (Figure 5). The distribution of VOCs within the plume indicates contributions from several source areas via direct recharge, hydrologic communication with Bear Creek, and inflow of shallow groundwater from the Aquitard. Plume constituents in the upper part of BCV are TCE, PCE, and 1,2-dichloroethene (1,2-DCE); probable source areas are Spoil Area I, the S-3 Site, and possibly another source area (the Fire Training Facility) located in the East Fork Regime. The primary inputs to the plume occur from the Rust Spoil Area or a nearby source in the Bear Creek floodplain (TCE), the Boneyard/Burnyard/HCDA (TCE and 1,2-DCE), Sanitary Landfill I (1,1,1-TCA and 1,1-DCA), and discharge from the Bear Creek tributary (NT-7) that traverses BG-A North and A South (1,2-DCE and 1,2-DCA). As shown in the following data summary, the CY 1998 VOC results for most of the Aquifer wells do not differ significantly from respective VOC results obtained during CY 1997 (as indicated by maximum summed concentrations of chloroethenes, chloroethanes and chloromethanes).

CY 1998 Maximum Summed VOC Concentrations for Surveillance Monitoring Aquifer Wells

\begin{tabular}{|c|c|c|c|c|c|c|}
\hline \multirow{3}{*}{$\begin{array}{c}\text { Well } \\
\text { Number }\end{array}$} & \multicolumn{6}{|c|}{ Maximum Summed VOC Concentration $(\mu \mathrm{g} / \mathrm{L})$} \\
\hline & \multicolumn{2}{|c|}{ Chloroethenes } & \multicolumn{2}{|c|}{ Chloroethanes } & \multicolumn{2}{|c|}{ Chloromethanes } \\
\hline & 1997 & 1998 & 1997 & 1998 & 1997 & 1998 \\
\hline GW-053 & 23 & 25 & 7 & 6 & - & . \\
\hline GW-056 & . & 9 & . & & & \\
\hline GW-226 & NS & 183 & NS & 1 & NS & 5 \\
\hline GW-311 & 12 & 10 & . & . & 2 & 2 \\
\hline GW-315 & 30 & 23 & . & . & & - \\
\hline GW-695 & 10 & 9 & . & . & 1 & . \\
\hline GW-703 & 17 & 27 & . & 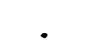 & 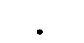 & . \\
\hline GW-704 & 110 & 89 & 3 & 2 & 2 & 1 \\
\hline GW-706 & 16 & 20 & . & . & . & . \\
\hline GW-724 & 45 & 137 & . & . & . & 1 \\
\hline GW-725 & 16 & 49 & . & . & . & 1 \\
\hline GW-738 & 45 & 39 & . & . & 1 & . \\
\hline GW-740 & 76 & 75 & . & 1 & 2 & 3 \\
\hline
\end{tabular}

Dissolved chloroethenes (PCE, TCE, and cis-1,2-DCE) were detected in the groundwater samples from Aquifer well GW-315 during CY 1998, which is completed at a depth of $104 \mathrm{ft}$ bgs on the northern flank of Chestnut Ridge south of Spoil Area I (Figure 6), and the maximum summed VOC concentrations in these samples are dominated by PCE $(11-12 \mu \mathrm{g} / \mathrm{L})$. These low-flow sampling results are consistent with historical (conventional sampling) data for the well and reflect input of dissolved chloroethenes from Spoil Area I or possibly the Fire Training Facility, which is a confirmed source of chloroethenes in the East Fork Regime about 1,000 ft east of the well (DOE 1997). As illustrated by PCE data, chloroethene concentrations in the groundwater at well GW-315 have decreased about 50\% from levels evident in $1991(19-38 \mu \mathrm{g} / \mathrm{L})$. 
Monitoring results for Aquifer well GW-311 obtained during CY 1998 are consistent with historical data and show relatively low levels of TCE $(8-10 \mu \mathrm{g} / \mathrm{L})$, along with trace levels $(1 \mu \mathrm{g} / \mathrm{L})$ of carbon tetrachloride and chloroform. Dissolved VOCs in the shallow groundwater ( $40 \mathrm{ft} \mathrm{bgs}$ ) at well GW-311, located on the south side of the Rust Spoil Area (Figure 6), reflect contaminant migration from that site or an unidentified nearby source in Bear Creek floodplain. Historic data show that TCE concentrations have decreased more than $50 \%$ since $1991(27-35 \mu \mathrm{g} / \mathrm{L})$. The rate of decrease suggests that TCE concentrations may soon drop below the $5 \mu \mathrm{g} / \mathrm{L}$ MCL.

The TCE concentrations $(110-180 \mu \mathrm{g} / \mathrm{L}$ ) reported for shallow (45 - $55 \mathrm{ft}$ bgs) well GW-226 are the highest TCE concentrations reported for any of the Aquifer wells during CY 1998. However, the CY 1998 TCE (low-flow sampling) results are inconsistent with historic (conventional sampling) results for well GW-226 and show a significant increase since the well was last sampled in May 1991 (see Section 3.3). As previously noted for total uranium (Section 3.1.2) concentrations, the elevated VOC concentrations in samples from well GW-226 probably reflect inflow of contaminated groundwater from the Boneyard/Burnyard/HCDA, the primary source of TCE and cis-1,2-DCE (and uranium) in shallow groundwater downgradient of the Oil Landfarm WMA (see Section 2.4.2).

Low concentrations of PCE, TCE, cis-1,2-DCE, VC, and 1,1-DCA were reported for the CY 1998 samples from Aquifer well GW-053, with cis-1,2-DCE $(11-15 \mu \mathrm{g} / \mathrm{L})$ as the primary compound. The well is completed near the Aquitard/Aquifer geologic contact at a depth of $33 \mathrm{ft}$ bgs about $500 \mathrm{ft}$ south of the BCBG WMA (Figure 6), and results for the well reflect inflow of shallow contaminated groundwater from the Aquitard beneath BG-A South. The CY 1998 low-flow sampling results are consistent with historical (conventional sampling) data for the well and show decreasing concentration trends from 1990 through 1994, followed by fairly stable concentrations for each compound since CY 1995.

Trichloroethene is the primary VOC present in the A.quifer at Exit Pathway Pickets A, B, and C. Based on aggregate average TCE concentrations determined from low-flow and conventional sampling results for the wells at each Picket, long-term concentration trends are generally stable and not clearly increasing or decreasing (Figure 14). The average TCE concentrations are consistently highest at Picket C, lower at Picket B, and rarely above the detection limit at Picket A (Figure 14). The long-term TCE concentration trends for most of the individual wells are generally decreasing, but data for wells GW-724 (Picket C) and GW-694 (Picket B) show generally increasing long-term TCE concentration trends (see Section 3.3).

Results for the wells at Exit Pathway Picket C that were sampled during CY 1998 (Figure 7) are consistent with respective historical data and reflect strike-parallel transport of TCE from the Rust Spoil Area in the shallow karst network (GW-738) and deeper bedrock (GW-724, GW-725, and GW-740). Trace concentrations (1 - 3 $\mu \mathrm{g} / \mathrm{L}$ ) of carbon tetrachloride (GW-725 and GW-740) suggest migration from another upgradient source, possibly the S-3 Site. 
Results for Exit Pathway Picket B wells GW-695, GW-703, GW-704, and GW-706 are consistent with respective historical data and reflect the TCE-dominated composition of the dissolved VOC plume in the Aquifer downgradient of the Oil Landfarm WMA. Considering that the highest summed VOC concentrations occur in the groundwater at well GW-704, which is the deepest ( $256 \mathrm{ft} \mathrm{bgs}$ ) well in Exit Pathway Picket B, the composition of the dissolved VOC plume reflects strike-parallel transport from source areas in the upper reaches of Bear Creek (i.e., the Rust Spoil Area) and vertical influx via the losing reach of Bear Creek south of Sanitary Landfill I (DOE 1997). Relatively low $(<10 \mu \mathrm{g} / \mathrm{L})$ concentrations of 1,1-DCE and 1,2-DCE in the groundwater at these wells may be from degradation of TCE, but trace levels $(1 \mu \mathrm{g} / \mathrm{L})$ of $1,1-\mathrm{DCA}$ and chloroform in the groundwater at well GW-704 suggest influx from sources in the Boneyard/Burnyard/HCDA or Sanitary Landfill I (portions of both sites directly overlie the Maynardville Limestone).

Dissolved VOCs were detected only in one groundwater sample collected from any of the monitoring wells that comprise Exit Pathway Picket A. Very low levels of PCE $(5 \mu \mathrm{g} / \mathrm{L}), \mathrm{TCE}(2 \mu \mathrm{g} / \mathrm{L})$, and cis-1,2-DCE $(2 \mu \mathrm{g} / \mathrm{L})$ were reported for the July 27,1998 sample from well GW-056, completed at $55 \mathrm{ft}$ bgs (Figure 7). However, these compounds have been detected in only two samples (in CY 1991) collected from the well before July 1998 and were not detected in the February 1999 sample from GW-056. The VOCs in the July 1998 sample from GW-056 may represent a pulse of contaminated groundwater in the shallow groundwater system near Bear Creek at Exit Pathway Picket A.

\subsubsection{Radioactivity}

Evaluation of groundwater quality with respect to radiological contamination was based on CY 1998 results for gross alpha and gross beta that exceed the associated minimum detectable activity (MDA) and counting error (the value that expresses the degree of analytical uncertainty) reported for each sample. Gross alpha and gross beta results that meet these DQO criteria were reported for a total of 40 groundwater samples from 17 of the monitoring wells used for Surveillance Monitoring during CY 1998 (Table 5). Considering the characteristic variability of the analytical results for gross alpha and gross beta, these results are generally consistent with historical data and do not indicate any significant changes in the overall extent of radiological contamination in the Bear Creek Regime, or any significant differences between radiological results obtained from conventional sampling and low-flow sampling. The following discussion highlights sampling locations with gross alpha and gross beta activity above $15 \mathrm{pCi} / \mathrm{L}$ and $50 \mathrm{pCi} / \mathrm{L}$, respectively.

Elevated gross alpha activity (i.e., gross alpha $>15 \mathrm{pCi} / \mathrm{L}$ ) basically reflects the extent of ${ }^{234} \mathrm{U}$ and ${ }^{238} \mathrm{U}$ in the groundwater (DOE 1997) and mainly occurs in the Aquitard near the S-3 Site and the Boneyard/Burnyard and in the Aquifer downgradient of each site (Figure 5). Although detected in samples from 10 monitoring wells, only the following Aquitard and Aquifer monitoring wells sampled for Surveillance Monitoring purposes in CY 1998 had elevated gross alpha activity. 
CY 1998 Gross Alpha Activity Greater Than $15 \mathrm{pCi} / \mathrm{L}$

\begin{tabular}{|c|c|c|c|c|c|}
\hline \multirow{2}{*}{\multicolumn{2}{|c|}{$\begin{array}{c}\text { Sampling } \\
\text { Point }\end{array}$}} & \multicolumn{4}{|c|}{ Gross Aipha Activity (pCi/L) } \\
\hline & & 1st Qtr. 1997 & 3rd Qtr. 1997 & 1st Otr. 1998 & 3rd Otr. 1998 \\
\hline AQT & $\begin{array}{l}\text { GW-276 } \\
\text { GW-537 }\end{array}$ & $\begin{array}{c}360 \pm 50 \\
.\end{array}$ & $340 \pm 30$ & $\begin{array}{r}140 \pm 21 \\
18 \pm 12\end{array}$ & . \\
\hline $\mathrm{AQF}$ & $\begin{array}{l}\text { GW-706 } \\
\text { GW-684 }\end{array}$ & $\begin{array}{c}45 \pm 11 \\
{[13 \pm 6]}\end{array}$ & $\begin{array}{c}29 \pm 7 \\
{[13 \pm 5]}\end{array}$ & $\begin{array}{c}42 \pm 9 \\
{[12 \pm 4.4]}\end{array}$ & $\begin{array}{l}42 \pm 9.1 \\
22 \pm 6.2\end{array}$ \\
\hline
\end{tabular}

Elevated gross beta activity, as defined by results that exceed the Safe Drinking Water Act (SDWA) screening level of $50 \mathrm{pCi} / \mathrm{L}$, also occurs in the Aquitard and Aquifer downgradient of the S-3 Site and the Boneyard/Burnyard (Figure 5) but is much more extensive than elevated gross alpha activity in the Aquifer and primarily reflects transport of ${ }^{99} \mathrm{Tc}$ from the S-3 Site (DOE 1997). Gross beta was detected in 26 samples from 15 wells sampled in CY 1998 but exceeded $50 \mathrm{pCi} / \mathrm{L}$ only in the three wells shown below.

\begin{tabular}{|c|c|c|c|c|c|}
\hline \multirow{2}{*}{\multicolumn{2}{|c|}{$\begin{array}{c}\text { Sampling } \\
\text { Point }\end{array}$}} & \multicolumn{4}{|c|}{ Gross Beta Activity (pCi/L) } \\
\hline & & 1st Qtr. 1997 & 3rd Qtr. 1997 & 1st Qtr. 1998 & 3rd Qtr. 1998 \\
\hline AQT & $\begin{array}{l}\text { GW-276 } \\
\text { GW-537 }\end{array}$ & $\begin{array}{l}680 \pm 89 \\
420 \pm 28\end{array}$ & $\begin{array}{l}790 \pm 27 \\
550 \pm 60\end{array}$ & $\begin{array}{l}590 \pm 24 \\
440 \pm 32\end{array}$ & $380 \pm 27$ \\
\hline AQF & GW-706 & $73 \pm 13$ & $67 \pm 8$ & $130 \pm 11$ & $140 \pm 12$ \\
\hline
\end{tabular}

Shallow and deep groundwater at the S-3 Site contains a heterogeneous mixture of several alphaand beta-emitting radionuclides, including ${ }^{99} \mathrm{Tc},{ }^{234} \mathrm{U}$, and ${ }^{238} \mathrm{U}$. Each of these radionuclides were detected above MDAs in the groundwater samples collected from well GW-276, with the highest concentrations reported for ${ }^{99} \mathrm{Tc}(970 \pm 19 \mathrm{pCi} / \mathrm{L})$ and ${ }^{38} \mathrm{U}(240 \pm 31 \mathrm{pCi} / \mathrm{L})$. As with other contaminants in the groundwater at this well, historical gross alpha and gross beta results show that radionuclide concentrations have deceased substantially since the late $1980 \mathrm{~s}$, but gross beta has generally decreased more rapidly. For example, gross beta activity decreased from more than $10,000 \mathrm{pCi} / \mathrm{L}$ in March 1988 to $680 \pm 89 \mathrm{pCi} / \mathrm{L}$ in March 1998 , whereas gross alpha activity decreased from about $3,000 \mathrm{pCi} / \mathrm{L}$ to $360 \pm 50 \mathrm{pCi} / \mathrm{L}$ over this same period. Alpha activity levels are probably maintained by the slow release of alpha-emitting isotopes adsorbed to sludges remaining in the S-3 Ponds and mineral surfaces in the Aquitard, whereas more rapidly decreasing beta activity reflects the greater flushing of ${ }^{99} \mathrm{Tc}$ from the shallow flow system, which is more mobile and less readily adsorbed in the subsurface (DOE 1997).

The CY 1998 gross alpha and gross beta results for groundwater samples from well GW-537 are generally consistent with historical data and clearly illustrate the differential retardation of radionuclides in the Aquitard. Gross alpha has been detected in 16 of the 30 samples collected from the well since January 1990 , and results exceeded $15 \mathrm{pCi} / \mathrm{L}$ in only nine of these samples. The fairly low alpha activity in groundwater at well GW-537 reflects substantial attenuation of uranium isotopes (and other alpha-emitting radionuclides) in the Aquitard west of the S-3 Site. However, the elevated gross beta activity in groundwater at well GW-537 reflects lesser retardation of ${ }^{99} \mathrm{Tc}$ and substantially greater strike-parallel transport from the $\mathrm{S}-3 \mathrm{Site}:{ }^{99} \mathrm{Tc}$ activities above $1,000 \mathrm{pCi} / \mathrm{L}$ 
were reported for samples collected from well GW-537 in CY 1995. Historical gross beta results for well GW-537 show significant temporal fluctuations but a generally upward long-term trend (see Section 3.3).

Gross alpha and gross beta activity in the Aquifer is from uranium isotopes (primarily ${ }^{234} \mathrm{U}$ and ${ }^{238} \mathrm{U}$ ) and ${ }^{99} \mathrm{Tc}$. Uranium isotopes enter the Aquifer via inflow from the buried tributary of Bear Creek that extends beneath the S-3 Site, direct recharge from the Boneyard/Burnyard (and inflow from the NT-3 catchment), and inflow from tributary catchments to the east (NT-6) and west (NT-7 and NT-8) of BG-A North and BG-A South (DOE 1997). Although uranium isotopes may account for both gross alpha and gross beta activity in the groundwater at some Aquifer wells, particularly those near the Boneyard/Burnyard, the distribution of gross beta activity in the Aquifer generally delineates the extent of ${ }^{99} \mathrm{Tc}$ transport and reflects essentially identical patterns of nitrate and ${ }^{99} \mathrm{Tc}$ migration from the S-3 Site (DOE 1997).

As illustrated by the maximum gross alpha (Figure 15) and gross beta activity (Figure 16) reported for each of the Exit Pathway Picket wells that were sampled for Surveillance Monitoring purposes during CY 1998, radioactivity is highest in the groundwater at Exit Pathway Picket B. Long-term trends are generally decreasing in the groundwater throughout the Aquifer and probably reflect reduced flux of isotopes following closure of the S-3 Site. Discharge of contaminated groundwater and surface water from the NT- 1 and NT-2 catchments and inflow along the losing reach of Bear Creek south of Sanitary Landfill I probably explains why gross alpha and gross beta activity is higher in the groundwater at Exit Pathway Picket B than in the groundwater upgradient at Exit Pathway Picket $\mathrm{C}$ or downgradient at Exit Pathway Picket A. Steady influx of uranium isotopes from the Boneyard/Burnyard also probably accounts for the more stable long-term trends in the groundwater at Exit Pathway Picket B compared to the decreasing long-term trends in the groundwater at Exit Pathway Picket C. Lower levels of radioactivity in the groundwater at Exit Pathway Picket C reflects substantial attenuation of uranium isotopes along strike-parallel flowpaths in the Aquifer downgradient of the S-3 Site.

As noted for nitrate (see Section 3.1) and total uranium (see Section 3.2) concentrations, gross alpha and gross beta activities reported for the groundwater samples collected from well GW-706 at Exit Pathway Picket B were higher than results for all of the other Aquifer wells sampled in CY 1998 (Table 5). Elevated radioactivity in the groundwater at well GW-706, which is completed at a depth of $182.5 \mathrm{ft}$ bgs in the upper part of the Maynardville Limestone (Figure 7), probably reflects influx of uranium isotopes from the Boneyard/Burnyard.

Gross alpha or beta activity above the associated MDA and counting error was reported for at least one groundwater sample collected from each of the Exit Pathway Picket A wells that were sampled during CY 1998 (Table 5) with the highest levels reported for wells GW-683 and GW-684. Results for these wells, which are completed in the lower Knox Group and upper Maynardville Limestone at respective depths of $197 \mathrm{ft}$ bgs and $128 \mathrm{ft}$ bgs (Figure 7), may reflect migration of uranium isotopes from the Boneyard/Burnyard into successively higher hydrostratigraphic zones in the Maynardville Limestone and ultimately into the lower Copper Ridge Dolomite. However, considering attenuation during transport from this site, which is about a mile east of Exit Pathway Picket $A$, influx of uranium isotopes discharged from the Bear Creek tributaries that drain the BCBG 
WMA seems a more likely source of the radioactivity in the groundwater at these wells. This also may explain the relatively stable long-term trends at Exit Pathway Picket A (Figure 15).

\subsection{Exit Pathway/Perimeter Monitoring}

The CY 1998 monitoring results reported for the following Aquifer wells, springs that discharge into Bear Creek, surface water stations located along the main channel of Bear Creek and NT-1 were evaluated for the purposes of Exit Pathway/Perimeter Monitoring.

CY 1998 Sampling Locations Used for Exit Pathway/Perimeter Monitoring

\begin{tabular}{|c|c|c|c|c|c|}
\hline \multicolumn{3}{|c|}{ Monitoring Wells } & \multirow{2}{*}{ Springs } & \multirow{2}{*}{\multicolumn{2}{|c|}{ Surface Water Stations }} \\
\hline Number & \multicolumn{2}{|c|}{$\begin{array}{l}\text { Monitored Interval Depth } \\
\text { (ft bgs) }\end{array}$} & & & \\
\hline GW-712 & 441.5 & - $\quad 457.5$ & SS-1 & BCK -00.63 & BCK -09.40 \\
\hline GW-713 & 305.0 & 315.2 & SS-4 & BCK-04.55 & BCK-10.60 \\
\hline GW-714 & 115.1 & 145.0 & SS-5 & BCK-07.75 & BCK-11.97 \\
\hline GW-715 & 32.0 & -44.0 & SS-6 & BCK-07.87 & NT-01 \\
\hline
\end{tabular}

Bear Creek and the Maynardville Limestone are the primary conduits for surface water and groundwater contaminants to migrate from waste sites in the Bear Creek Regime beyond the ORR property line.

Groundwater or surface water samples were collected semiannually from all but two surface water sampling locations during CY 1998; samples were collected from BCK-07.87 in August and from and BCK-10.60 in February (Table 2). Groundwater samples from Aquifer wells GW-712, GW-713, GW-714, and GW-715 and grab samples from the springs and surface water stations were obtained in accordance with Y-12 Plant GWPP technical procedures (see Section 3.1). Samples from each of the wells, springs, and surface water stations were analyzed for inorganics (major ions and trace metals), VOCs, and selected radioanalytes (Table 3). These analytical results, along with historical data for each sampling location, serve as the basis for the following evaluation of surface water and groundwater quality where contaminants from the Y-12 Plant are most likely to migrate beyond the boundaries of the Bear Creek Regime. For Exit Pathway/Perimeter Monitoring purposes the regime is divided into three sections based on surface water drainage areas: Upper Bear Creek is the main channel between the headwaters and BCK-11.97; Middle Bear Creek is the section of the main channel between BCK-11.97 and BCK-09.40; and Lower Bear Creek includes the section of the main channel downstream of BCK-09.40 (Figure 6).

Evaluation of the CY 1998 monitoring data for the purposes of Exit Pathway/Surveillance Monitoring focuses on the principal components of the groundwater contaminant plumes in the Bear Creek Regime: inorganics (nitrate and uranium), VOCs, and radioactivity (gross alpha and gross beta). As shown in the following summary of CY 1998 monitoring results, one or more of these contaminants were detected in at least one sample from all sampling locations except for well GW-713 at Exit Pathway Picket W. 
CY 1998 Maximum Contaminant Concentrations at Exit Pathway/Perimeter Monitoring Locations

\begin{tabular}{|c|c|c|c|c|c|c|c|c|}
\hline \multirow{2}{*}{ Sampling Point } & \multicolumn{2}{|c|}{ Inorganics (mg/L) } & \multicolumn{4}{|c|}{ Organics $(\mu \mathrm{g} / L)$} & \multicolumn{2}{|c|}{$\begin{array}{l}\text { Radioactivity } \\
\text { (pCi/L) }\end{array}$} \\
\hline & Nitrate & Uranium & PCE & TCE & $\begin{array}{l}\text { cis-1,2 - } \\
\text { DCE }\end{array}$ & $\begin{array}{l}\text { Carbon } \\
\text { Tet. }\end{array}$ & $\begin{array}{l}\text { Gross } \\
\text { Alpha }\end{array}$ & $\begin{array}{c}\text { Gross } \\
\text { Beta }\end{array}$ \\
\hline $\begin{array}{r}\text { Upper Bear Creek } \\
\text { NT-01 } \\
\text { SS-1 } \\
\text { BCK-11.97 }\end{array}$ & $\begin{array}{c}252 \\
11.6 \\
80.1\end{array}$ & $\begin{array}{l}0.149 \\
0.058 \\
0.113\end{array}$ & $\begin{array}{c}7 \\
(1) \\
(1)\end{array}$ & : & . & . & $\begin{array}{l}45 \\
29 \\
35\end{array}$ & $\begin{array}{c}500 \\
30 \\
190\end{array}$ \\
\hline $\begin{array}{r}\text { Middle Bear Creek } \\
\text { BCK-10.60 } \\
\text { SS-4 } \\
\text { SS-5 } \\
\text { BCK-09.40 }\end{array}$ & $\begin{array}{l}8.13 \\
34.8 \\
14 \\
10.3\end{array}$ & $\begin{array}{l}0.097 \\
0.0971 \\
0.0551 \\
0.0922\end{array}$ & $\begin{array}{l}\dot{\bullet} \\
\dot{.} \\
\dot{ }\end{array}$ & $\begin{array}{l}14 \\
(2) \\
(1)\end{array}$ & $\begin{array}{l}\text { 11 } \\
(3) \\
(2)\end{array}$ & $\begin{array}{l}\dot{6} \\
\dot{\cdot}\end{array}$ & $\begin{array}{l}37 \\
38 \\
31 \\
33\end{array}$ & $\begin{array}{c}29 \\
110 \\
46 \\
38\end{array}$ \\
\hline $\begin{array}{r}\text { Lower Bear Creek } \\
\text { BCK-07.87 } \\
\text { GW-715 } \\
\text { GW-714 } \\
\text { GW-713 } \\
\text { GW-712 } \\
\text { SS-6 } \\
\text { BCK-07.75 } \\
\text { BCK-04.55 } \\
\text { BCK-00.63 }\end{array}$ & $\begin{array}{c}18.8 \\
4.01 \\
\cdot \\
\cdot \\
0.05 \\
2.29 \\
5.76 \\
1.4 \\
1.01\end{array}$ & $\begin{array}{l}0.0659 \\
0.0006 \\
\cdot \\
\cdot \\
\dot{0.034} \\
0.0548 \\
0.018 \\
0.0127\end{array}$ & $\begin{array}{l}\dot{.} \\
\dot{.} \\
\dot{.} \\
\dot{.} \\
\dot{.} \\
\dot{.}\end{array}$ & $\begin{array}{l}\dot{.} \\
\dot{.} \\
\dot{.} \\
\dot{.} \\
\dot{.}\end{array}$ & $\begin{array}{l}\cdot \\
\dot{\cdot} \\
\dot{ } \\
\dot{(1)} \\
(1) \\
\dot{ }\end{array}$ & $\begin{array}{l}. \\
. \\
. \\
. \\
. \\
. \\
. \\
.\end{array}$ & $\begin{array}{c}25 \\
\dot{3.4} \\
\dot{ } \\
10 \\
33 \\
16 \\
6.6\end{array}$ & $\begin{array}{r}65 \\
11 \\
. \\
12 \\
30 \\
. \\
.\end{array}$ \\
\hline $\begin{array}{l}\text { Note: Results for each } \\
\text { "." not detecte }\end{array}$ & apling & t may b & SIII & $\begin{array}{l}\text { than } \\
\text { stand }\end{array}$ & $\begin{array}{l}\text { e sampli } \\
\text { (MCL }\end{array}$ & $\begin{array}{l}\text { date. ( } \\
\text { UTL). }\end{array}$ & Estim: & value; \\
\hline
\end{tabular}

Results for these sampling locations are generally consistent with respective historical data and reflect migration of contaminants from the S-3 Site, the Rust Spoil Area, the Oil Landfarm WMA (including the Boneyard/Burnyard), the BCBG WMA, or a combination of these source areas. Contaminant concentrations in Bear Creek generally decrease with distance from the S-3 Site, but localized segments of the creek show increases in the concentration of some contaminants with distance from the S-3 Site that reflects input of contaminated groundwater from other waste sites or from the Aquifer. Contaminant concentrations in groundwater discharging from springs are highest at SS-4, which indicates input of contaminated groundwater downgradient of spring SS-1. Results for the groundwater samples from wells at Exit Pathway Picket W show that these wells continue to monitor groundwater downgradient of the contaminant plumes in the Aquifer.

\subsubsection{Upper Bear Creek}

The surface water quality in the upper reaches of Bear Creek primarily reflects discharge of contaminated groundwater from the water table interval in the Aquitard and Aquifer downgradient of the S-3 Site. Discharge of contaminated groundwater from the Aquitard is demonstrated by 
results for samples collected from tributary NT-1, and results for spring SS-1 show influx of contaminated groundwater from the Aquifer. The highest levels of nitrate, PCE, and gross beta activity were reported for samples from NT-1, suggesting migration along strike from the S-3 Site in the Aquitard for these contaminants. As indicated by the nitrate concentrations and gross alpha activities reported for BCK-11.97 since 1990, contaminant levels in Upper Bear Creek fluctuate seasonally but generally decrease with time (Figure 17). Decreasing contaminant concentrations in the upper part of Bear Creek mirror the decreasing concentration trends evident in the shallow groundwater near the S-3 Site. Contaminant concentrations at BCK-11.97 are generally highest during the seasonally dry periods of the year (summer and fall) when the bulk of the flow in the creek is from groundwater discharge (Figure 17). These results suggest that contaminant concentrations in Bear Creek are generally controlled by varying degrees of seasonal dilution.

\subsubsection{Middle Bear Creek}

Surface water quality in Bear Creek downstream of BCK-11.97 reflects contaminant transport from the upper reaches of the creek, from the Boneyard/Burnyard (uranium, TCE, and cis-1,2-DCE), and from the Burial Grounds WMA (TCE and cis-1,2-DCE). Much of this section of the creek loses flow to the Aquifer, particularly the section of the channel immediately south of Sanitary Landfill I, which plays an important role in transferring contaminants from the creek to the groundwater.

Concentrations of nitrate, a "signature" constituent of the plume that originates from the S-3 Site, generally decrease steadily with distance from the site. However, concentrations of other contaminants do not show as strong a decrease with distance downstream, which shows influx of contaminants from other sources. For example, maximum nitrate concentrations and gross beta activity at $\mathrm{BCK}-10.60$ are significantly lower (about $90 \%$ ) than the maximum levels reported for BCK-11.97, whereas the uranium concentration at BCK-10.60 is similar (14\% lower) and gross alpha activity is slightly higher (6\%) than at BCK-11.97. These results reflect input of uranium from the Boneyard/Burnyard, which lies between BCK-11.97 and BCK-10.60 (Figures 2 and 5).

As noted in Section 3.1.4, surface water in each tributary that drains the Bear Creek Burial Grounds WMA is radiologically contaminated and the highest activities are evident in the southern branch of NT-8 (DOE 1997). Inflow of groundwater and surface water from the catchments of these tributaries, as well as from springs SS-4 and SS-5, probably accounts for the gross alpha and gross beta activity in Bear Creek at BCK-09.40. The long-term trend for nitrate concentration at BCK-09.40 shows a general decrease, while the long-term trend for gross alpha activity remains fairly constant (Figure 17).

Discharge of groundwater from springs SS-4 and SS-5 sustains flow in the Bear Creek during seasonally low flow periods (DOE 1997) and contributes to surface water contamination downstream of BCK-11.97. As shown in the preceding summary of CY 1998 data, groundwater discharged from both springs contains nitrate, uranium, TCE, cis-1,2-DCE, gross alpha (i.e., uranium isotopes), and gross beta (i.e., uranium isotopes and/or ${ }^{99} \mathrm{Tc}$ ), with the higher levels of each contaminant reported for spring SS-4. Contaminant concentrations reported for SS-4 also are higher than the levels reported for SS-1, located about a mile closer to the S-3 Site. Higher concentrations in the 
groundwater discharged from spring SS-4 probably reflect transfer of contaminants from Bear Creek into the Aquifer along the losing reach of the creek upgradient of the spring (DOE 1997).

\subsubsection{Lower Bear Creek}

As shown in the preceding data summary, surface water downstream of BCK-09.40 contains slightly elevated concentrations of several contaminants, but only uranium and gross alpha activity are consistently above the applicable UTL for uranium and the $15 \mathrm{pCi} / \mathrm{L} \mathrm{MCL}$ for gross alpha. As observed for the sampling locations in upper and middle Bear Creek, long-term trends for nitrate concentration and gross alpha activity show a general decrease at BCK-04.55 (Figure 17). Results for BCK-00.63 reflect surface water quality as it exits the regime and total uranium is the only constituent with results that exceed the UTL $(0.005 \mathrm{mg} / \mathrm{L})$. However, the maximum uranium concentration $(0.0127 \mathrm{mg} / \mathrm{L})$ at BCK- 00.63 does not exceed the proposed MCL for uranium $(0.02 \mathrm{mg} / \mathrm{L})$.

Samples of the groundwater discharging from spring SS-6, located between BCK-07.87 and BCK-07.75 (Figure 6), contain nitrate, uranium, cis-1,2-DCE, and gross alpha and beta activity, but only the uranium concentration exceeds the applicable UTL and/or proposed MCL. The total uranium concentrations $(0.0102-0.034 \mathrm{mg} / \mathrm{L})$ in samples from SS-6 are near or above the proposed MCL for uranium $(0.02 \mathrm{mg} / \mathrm{L})$, but are inconsistent with historic data for the spring. Total uranium was not detected in the 15 samples collected from the spring between August 1990 and July 1995, and was substantially lower $(0.00625 \mathrm{mg} / \mathrm{L})$ in the February 1999 sample from SS-6. The elevated uranium concentrations in CY 1998 may be an analytical artifact or potentially may represent a pulse of contaminated groundwater in the shallow flow system near Bear Creek.

Groundwater contaminants were detected, but did not exceed MCLs or UTLs, in samples obtained during CY 1998 from the wells at Exit Pathway Picket W, located near BCK-07.87 (Figure 6). The CY 1998 results are generally consistent with historic data and show sporadic detection of gross alpha and gross beta activity and low levels of nitrate and uranium in samples from wells GW-714 and GW-715. The radioactivity results may represent analytical variability and not actual groundwater conditions. Nitrate and uranium concentrations in samples from well GW-714, as shown in the following summary, sharply decreased when low-flow sampling was initiated in CY 1998.

Comparison of Nitrate and Uranium Concentrations at Well GW-714

Using Conventional and Low-Flow Sampling Methods

\begin{tabular}{|r|c|c|c|c|c|c|}
\hline \multirow{2}{*}{ Analyte } & \multicolumn{5}{|c|}{ Concentration (mg/L) } \\
\cline { 2 - 7 } & \multicolumn{5}{|c|}{ Conventional Sampling } & Low-Flow Sampling \\
\cline { 2 - 7 } & Jan 96 & July 96 & Feb 97 & Aug 97 & Jan 98 & July 98 \\
\hline Nitrate & 3.56 & 1.29 & 3.57 & 2.62 & $<0.028$ & $<0.028$ \\
Total Uranium & 0.0029 & 0.0015 & 0.0031 & 0.0032 & $<0.0005$ & $<0.0005$ \\
\hline
\end{tabular}


The much lower nitrate and uranium concentrations in samples collected from well GW-714 using the low-flow sampling method suggest that the historical results for the well: (1) may be artifacts of the conventional sampling method that overstate the contamination in the groundwater near the well, or (2) may represent groundwater quality of a contaminated stratigraphic zone outside the zone of influence of the low-flow sampling method. If future monitoring results using the low-flow sampling method continue to show nitrate and uranium levels below the detection limit, it may be difficult to determine which sampling method provides the most representative data for the well.

\subsection{Contaminant Concentration Trends}

Monitoring data obtained since the late 1980 s and early 1990 s show indeterminant or generally decreasing long-term contaminant concentration trends for the majority of sampling locations in the Bear Creek Regime, including most of the CY 1998 sampling locations (Table 2). The decreasing concentration trends probably reflect a combination of several factors, including compliance with waste management regulations, waste minimization and source control measures, remedial actions, natural attenuation mechanisms (including biotic and/or abiotic degradation of VOCs), and, in some cases, changes in sampling procedures and analytical methods. For the purposes of DOE Order 5400.1A requirements, the following discussion is focused on CY 1998 sampling locations that exhibit increasing long-term contaminant concentration trends.

As shown in the following summary, clearly increasing long-term contaminant concentration trends are indicated by the monitoring data for seven of the CY 1998 sampling locations in the Bear Creek Regime.

CY 1998 Increasing Long-Term Concentration Trends

\begin{tabular}{|c|c|c|c|c|}
\hline \multicolumn{2}{|c|}{ Sampling Location } & Nitrate & voCs & Radioactivity \\
\hline Aquitard & $\begin{array}{l}\text { GW-537 } \\
\text { GW-627 } \\
\text { GW-653 }\end{array}$ &. & $\bullet$ & •. \\
\hline Aquifer & $\begin{array}{l}\text { GW-226 } \\
\text { GW-695 } \\
\text { GW-706 } \\
\text { GW-724 }\end{array}$ & $\begin{array}{l}\bullet \\
\bullet \\
\bullet\end{array}$ & $\begin{array}{l}\bullet \\
\bullet \\
\bullet\end{array}$ & : \\
\hline
\end{tabular}

These increasing trends reflect westward contaminant transport along strike in the Aquitard from the S-3 Site and the BCBG WMA and in the Aquifer from the S-3 Site and the Oil Landfarm WMA. Results for each of these sampling locations are described in the following discussion.

The CY 1998 gross beta results for groundwater samples from well GW-537 are generally consistent with historical data and show significant temporal fluctuations (some of which probably reflect analytical variability) but a generally upward long-term trend (Figure 18). Slow, westward migration of the center of mass of the S-3 Site contaminant plume may explain the increasing gross beta activity in the shallow groundwater at this well (DOE 1997). However, a slightly decreasing trend 
evident since the highest gross beta result $(713 \pm 88 \mathrm{pCi} / \mathrm{L})$ reported for the February 1994 sample (Figure 18) may reflect a pulse of ${ }^{99} \mathrm{Tc}$ (and other S-3 Site contaminants) in the shallow groundwater near well GW-537, as shown by the strontium and barium concentration trends (Figure 12).

The CY 1998 VOC results for well GW-627 reflect the steadily increasing PCE and TCE concentration trends evident since February 1990 (Figure 19). As noted in Section 3.1.3, the detection of these chloroethenes and the subsequent concentration increases indicate migration of VOCs at depth in the Aquitard; fate and transport modeling suggest it will take as long as 600 years for the PCE to migrate about 1,200 ft to NT-8 (DOE 1997). Compared to the historic (conventional sampling) VOC data (Figure 20), however, the CY 1998 (low-flow sampling) VOC results reflect a dramatic concentration increase $(>300 \%)$ and the preliminary low-flow sampling results obtained in March 1999 show similarly high PCE $(360 \mu \mathrm{g} / \mathrm{L})$ and TCE $(120 \mu \mathrm{g} / \mathrm{L})$ concentrations. Substantially higher VOC concentrations in samples obtained using the low-flow sampling method suggests that the conventional sampling method may: (1) dewater the well and volatilize the VOCs in the groundwater entering the well resulting in lower VOC concentrations in the samples, or (2) induce flow of uncontaminated groundwater into the well, thereby diluting the samples and reducing the VOC concentrations in the samples.

Aquitard well GW-653 is completed in the water table interval ( 26 to $29 \mathrm{ft} \mathrm{bgs}$ ) about $400 \mathrm{ft}$ west of well GW-627 (Figure 6) near the western edge of the VOC plume originating from BG-A South. As illustrated by 1,2-DCE (the principal compound) concentrations and groundwater elevations for well GW-653, concentrations within the shallow groundwater VOC plume are often highest during winter and spring when water levels are highest (Figure 19), which suggests seasonally variable flux of VOCs toward discharge areas in NT-8. Although dominated by these seasonal fluctuations, a slightly upward long-term concentration trend is evident.

Monitoring results for the groundwater samples collected from Aquifer well GW-226 in CY 1998 (low-flow sampling method) are inconsistent with historic data (conventional sampling method) for the well and show a reversal of the decreasing trends in nitrate and TCE concentrations (Figure 20). Conventional sampling results for nitrate concentrations fluctuated but decreased from about $4 \mathrm{mg} / \mathrm{L}$ in 1988 to below the detection limit in May $1991(<0.2 \mathrm{mg} / \mathrm{L})$. The CY 1998 low-flow sampling results show that nitrate has increased to $17 \mathrm{mg} / \mathrm{L}$. From November 1988 through May 1990, samples from well GW-226 had nearly equal concentrations of TCE and 1,2-DCE (Figure 20). Then from May 1990 through May 1991, TCE concentrations decreased from $11 \mu \mathrm{g} / \mathrm{L}$ to $3 \mu \mathrm{g} / \mathrm{L}$ and the 1,2-DCE concentrations increased from $16 \mu \mathrm{g} / \mathrm{L}$ to $29 \mu \mathrm{g} / \mathrm{L}$ (Figure 20). The concentration trends at that time appeared to reflect degradation of TCE to 1,2-DCE. However, the CY 1998 results reversed that trend with extremely high TCE (110 -180 $\mu \mathrm{g} / \mathrm{L})$ and much lower 1,2-DCE concentrations $(3-7 \mu \mathrm{g} / \mathrm{L}$ ). As noted previously, uranium concentrations (and gross alpha and beta activities) show a reversal from increasing to decreasing trends similar to 1,2-DCE (Figure 13). The significant increase in nitrate and TCE concentrations from 1991 to 1998 may reflect increased contamination over seven years or suggest that the conventional sampling method may have diluted the contaminant concentrations in samples from well GW-226 by inducing flow of uncontaminated groundwater into the well. 
The CY 1998 results for Aquifer well GW-695 are consistent with the historic data for the well and show low TCE levels $(<10 \mu \mathrm{g} / \mathrm{L})$ in all but three samples from the well (Figure 21). Although most of the historic data are estimated values below the reporting limit $(5 \mu \mathrm{g} / \mathrm{L})$, a clearly increasing concentration trend is evident for the well and the results have been at or above the MCL for TCE $(5 \mu \mathrm{g} / \mathrm{L})$ in the samples collected from well GW-695 since February 1996. Additionally, the highest TCE concentrations were reported for the well during March (seasonally high flow conditions) of 1997 and 1998 (Figure 21), which shows seasonal flux in the shallow groundwater at Exit Pathway Picket B (Figure 7).

Trichloroethene has been detected in every sample collected from Aquifer well GW-724 since May 1992 , and concentrations have fluctuated but generally increased from about $50 \mu \mathrm{g} / \mathrm{L}$ to about $130 \mu \mathrm{g} / \mathrm{L}$ (Figure 21). This well, located at Exit Pathway Picket C, is completed with a $12 \mathrm{ft}$ open interval more than $300 \mathrm{ft}$ bgs (Figure 7), and the increasing TCE levels potentially indicate increased flux along strike-parallel flowpaths at depth in the middle (Zone 4) of the Maynardville Limestone.

Monitoring results for well GW-706 show that nitrate concentrations fluctuated but generally decreased from 1991 to 1993, then steadily increased through 1998 (Figure 22). The significant fluctuations evident in the nitrate trend for well GW-706 between June 1991 and October 1993 show no consistent relationship to presampling water levels and the annual average nitrate concentrations steadily decreased from $43 \mathrm{mg} / \mathrm{L}$ in 1991 to $15 \mathrm{mg} / \mathrm{L}$ in 1993. The nitrate concentrations reported for well GW-706 after 1993 show much less fluctuation, which may reflect the change to semiannual sampling, and a generally increasing trend. As noted in Section 3.1, the CY 1998 low-flow sampling results are substantially higher than results for conventional sampling. 


\subsection{CONCLUSIONS AND RECOMMENDATIONS}

The groundwater and surface water quality data obtained during CY 1998 are generally consistent with historical results regarding the sources of contamination in the Bear Creek Regime, the types of contaminants from each source area, the pattern and extent of contaminant transport, and longterm contaminant trends. This conclusion is based on evaluation of the data for the primary groundwater and surface water contaminants (nitrate, barium, boron, strontium, uranium, PCE, TCE, gross alpha, and gross beta). A summary of significant findings based on the evaluation of these CY 1998 results for the purposes of DOE Order 5400.1A is provided below.

\subsection{Surveillance Monitoring}

The CY 1998 monitoring results reported for 27 monitoring wells, including 10 Aquitard wells and 17 Aquifer wells, were evaluated for the purposes of Surveillance Monitoring. These results indicate migration of contaminants from the S-3 Site and the BCBG WMA in the Aquitard, and influx/transport of contaminants from the S-3 Site, Spoil Area I, Rust Spoil Area (or nearby source in the Bear Creek floodplain), the Oil Landfarm WMA, and the BCBG WMA in the Aquifer. Evaluation of the Surveillance Monitoring data shows the following new or significant findings.

- The highest total uranium concentrations and radioactivities reported for groundwater in the Aquitard were in samples from well GW-276, located south (across strike) of the S-3 Site.

- Westward migration (along strike) of the contaminant plume originating from the S-3 Site was substantiated by the results for wells GW-085, GW-537, and GW-829. Samples from water table well GW-537 had the highest nitrate, barium, and strontium concentrations in the Bear Creek Regime and reflect upwelling along NT-2 from the plume in the bedrock interval. Gross beta activity is more than an order of magnitude higher than gross alpha activity at well GW-537, which reflects lesser retardation of ${ }^{99} \mathrm{Tc}$ than isotopic uranium.

- Mobilization of DNAPL encountered south (downdip) of BG-A South in January 1990 probably accounts for the coincident detection and subsequent increase of dissolved TCE and PCE in the groundwater at well GW-627.

- Low $\mathrm{pH}$ in groundwater (4-6) not associated with disposal activity at the S-3 Site was reported for four Aquitard wells: GW-008 at the Oil Landfarm WMA and GW-046, GW-287, and GW-653 at the BCBG WMA. The acidic sources are unknown but may reflect transport of acetic acid generated from the chemical degradation of 1,1,1-TCA (especially at well GW-046).

- The CY 1998 low-flow sampling results for nitrate and VOC concentrations are inconsistent with historical (conventional sampling) results for two Aquitard and four Aquifer wells. Significantly lower nitrate concentrations were reported for Aquitard well GW-829, located west of the S-3 Site, and for Aquifer wells at Exit Pathway Pickets C (GW-724 and GW-725) and $B(G W-621)$. These results show that the conventional sampling method may have 
induced flow of contaminated groundwater into these wells. Conversely, the CY 1998 nitrate concentrations at well GW-706 and VOC concentrations at well GW-627 are substantially higher than historical data, suggesting that the conventional sampling method induced flow of less contaminated groundwater into these wells.

- Although optimum geochemical conditions for biodegradation were not reported for any of the Surveillance Monitoring locations sampled in CY 1998, the high proportion of degradation products (e.g., cis-1,2-DCE and VC) in samples from wells GW-008 at the Oil Landfarm WMA and wells GW-046 and GW-053 at the BCBG WMA suggests transport of these compounds from upgradient areas where biodegradation of PCE has occurred.

- The CY 1998 results for well GW-226 are inconsistent with historic data (1988 - 1991). The historic results for cis-1,2-DCE, total uranium, and gross alpha activity showed significantly increasing trends through May 1991. The CY 1998 levels of these contaminants decreased dramatically from the levels reported in CY 1991, thereby reversing the long-term contaminant trends. Furthermore, nitrate and TCE concentrations, which had previously shown a decreasing trend, showed significant increases in CY 1998.

- Monitoring results for the wells sampled in CY 1998 that comprise Exit Pathway Pickets A, $B$, and $C$ show that TCE concentrations are highest at Picket $C$ and that nitrate, total uranium, and radioactivity are highest at Picket $\mathrm{B}$. This pattern of increasing concentrations along strike reflects input of contaminants from the Boneyard/Burnyard and from the losing reach of Bear Creek south of Sanitary Landfill I. Concentrations of all contaminants are lowest at Exit Pathway Picket A.

\subsection{Exit Pathway/Perimeter Monitoring}

The CY 1998 monitoring results reported for nine surface water stations, four springs that discharge into Bear Creek, and four Aquifer wells at the westernmost Exit Pathway Picket (Picket W) were evaluated for the purposes of Exit Pathway/Perimeter Monitoring. These results are generally consistent with historical data and show that contaminant concentrations generally decrease with distance from the S-3 Site, but localized segments of the Bear Creek show increases in the concentration of some contaminants with distance from the S-3 Site that reflects input of contaminated groundwater from other waste sites or from the Aquifer. A summary of significant findings is provided below.

- Bear Creek and the Maynardville Limestone are the primary conduits for surface water and groundwater contaminants to migrate beyond the ORR boundary and elevated concentrations are reported at much greater distance from the waste management sites in samples from the creek than in groundwater discharging from springs or from monitoring wells.

- The CY 1998 results for samples from Bear Creek are consistent with historical data and show that the concentrations of most of the principal groundwater contaminants (nitrate, uranium, VOCs, and gross alpha and gross beta activity) in samples collected upstream of 
BCK-09.40 exceed the applicable UTL and/or MCL. At BCK-00.63, the furthest downstream sampling location (about 12 kilometers from the S-3 Site), total uranium is the only contaminant of concern; the maximum CY 1998 uranium concentrations exceed the UTL for uranium but remain below the proposed MCL.

- Monitoring results for the springs sampled in CY 1998 are consistent with historic results and show that the concentration of all groundwater contaminants are highest in samples from SS-4, located more than a mile farther from the S-3 Site than spring SS-1. The increased contaminant levels at spring SS-4 reflect input from other sites (e.g., the Boneyard/Burnyard) and the losing reach of Bear Creek south of Sanitary Landfill I.

- The CY 1998 results for groundwater samples from the Exit Pathway Picket W wells show that all contaminant concentrations remain below applicable UTLs and MCLs. The low-flow sampling results for nitrate and uranium concentrations at well GW-714 are substantially lower than historical (conventional sampling) results, which suggests that the conventional sampling method induced flow of contaminated groundwater into the well.

\subsection{Contaminant Concentration Trends}

Increasing long-term contaminant concentration trends are indicated by the monitoring results for seven of the CY 1998 sampling locations in the Bear Creek Regime, including three Aquitard and four Aquifer wells. The increasing trends at Aquitard wells GW-537, GW-627, and GW-653 represent westward contaminant migration along strike at plume boundaries, while the increasing trends at the Aquifer wells GW-226, GW-695, GW-706, and GW-724 reflect the hydrochemical dynamics within the groundwater plumes. Monitoring results for the remaining CY 1998 sampling locations generally continue the decreasing (or indeterminant) concentration trends evident since the late 1980 s and early 1990 s.

\subsection{Recommendations}

Based on evaluation of the CY 1998 groundwater monitoring data, the following actions are recommended:

- A survey should be performed to assess the occurrence and diversity of bacteria in groundwater within monitoring wells. Several wells with historic data that reflect microbially-induced corrosion of stainless steel well screens or biodegradation of VOCs should be selected for downhole video camera inspection and subsequent microbial sampling.

- To determine and/or verify the effects on groundwater quality caused by different groundwater sampling methods, a comparison of contemporaneous analytical results for samples obtained using the low-flow and conventional sampling methods should be performed. Wells included in this study would be scheduled for monitoring during CY 2000 
(Y-12 GWPP or another program) and have low-flow sampling results that are significantly different from conventional sampling results. Groundwater samples would be collected semiannually from each selected well using the conventional sampling method within a few days after the scheduled low-flow sampling is complete. 


\subsection{REFERENCES}

AJA Technical Services, Inc. 1997. Evaluation of Calendar Year 1996 Groundwater and Surface Water Quality Data for the Bear Creek Hydrogeologic Regime at the U.S. Department of Energy Y-12 Plant, Oak Ridge Tennessee. Prepared for Lockheed Martin Energy Systems, Inc. (Y/SUB/97-KDS15V/4)

AJA Technical Services, Inc. 1999. Groundwater Protection Program Calendar Year 1998 Groundwater Monitoring Report, U.S. Department of Energy Y-12 Plant, Oak Ridge, Tennessee. Prepared for Lockheed Martin Energy Systems, Inc. (Y/SUB/99-MVM64V/1).

Chapelle, F.H. 1996. Identifying Redox Conditions That Favor the Natural Attenuation of Chlorinated Ethenes in Contaminated Ground-Water Systems. Reported in: Symposium on Natural Attenuation of Chlorinated Organics in Ground Water. U.S. Environmental Protection Agency, Office of Research and Development (EPA/540/R-96/509).

Dreier, R.B., D.K. Solomon, and C.M. Beaudoin. 1987. Fracture Characterization in the Unsaturated Zone of a Shallow Land Burial Facility. Flow and Transport Through Fractured Rock. American Geophysical Union Monograph 42.

Goldstrand, P.M. 1995. Stratigraphic Variations and Secondary Porosity Within the Maynardville Limestone in Bear Creek Valley, Y-12 Plant, Oak Ridge, Tennessee. Prepared for Martin Marietta Energy Systems, Inc. (Y/TS-1093).

Hasse, S. and H.L. King. 1990. Report and Preliminary Assessment of the Occurrence of Dense, Nonaqueous Phase Liquids in the Bear Creek Burial Grounds Hazardous Waste Disposal Unit at the Oak Ridge Y-12 Plant. Martin Marietta Energy Systems, Inc. (Y/TS-629).

Hinchee, R.E., J.A. Kittel, and H.J. Reisinger, eds. 1995. Applied Bioremediation of Petroleum Hydrocarbons. Batelle Press, Columbus, $\mathrm{OH}$.

HSW Environmental Consultants, Inc., Paradigm Data Services, Inc., and ORNL Environmental Sciences Division. 1995. Determination of Reference Concentrations for Inorganic Analytes in Groundwater at the Department of Energy Y-12 Plant, Oak Ridge, Tennessee. Prepared for Lockheed Martin Energy Systems, Inc. (Y/ER-234).

King, H.L. and C.S. Haase. 1987. Subsurface-Controlled Geological Maps for the Y-12 Plant and Adjacent Areas of Bear Creek Valley. Oak Ridge National Laboratory (ORNL/TM-10112).

Lockheed Martin Energy Systems, Inc. 1988. Environmental Surveillance Quality Control Program. (ES/ESH/INT-14). 
McCarty, P.L. 1996. Biotic and Abiotic Transformations of Chlorinated Solvents in Ground Water. Reported in: Symposium on Natural Attenuation of Chlorinated Organics in Ground Water. U.S. Environmental Protection Agency, Office of Research and Development (EPA/540/R96/509).

Martin Marietta Energy Systems, Inc. 1993. Y-12 Plant Groundwater Protection ProgramGroundwater Monitoring Program Data Management Plan (Y/SUB/93-TK532C/1).

Moore, G.K. 1988. Concepts of Groundwater Occurrence and Flow Near Oak Ridge National Laboratory. Oak Ridge National Laboratory (ORNL/TM-10969).

Moore, G.K. 1989. Groundwater Parameters and Flow System Near Oak Ridge National Laboratory. Oak Ridge National Laboratory (ORNL/TM-11368).

Moore, G.K. and L.E. Toran. 1992. Supplement to a Hydrogeologic Framework for the Oak Ridge Reservation, Oak Ridge, Tennessee. Oak Ridge National Laboratory (ORNL/TM-12191).

Saunders, J.A. and L.E. Toran. 1992. Evolution of CA-MG-SO 4 Type and NA-CA-CL-SO Type Water in Fractured Sedimentary Rock Near Oak Ridge, Tennessee. Oak Ridge National Laboratory (Y/TS-875/R2).

Shevenell, L.A. 1994. Chemical Characteristics of Waters in Karst Formations at the Oak Ridge Y-12 Plant. Oak Ridge National Laboratory (Y/TS-1001).

Shevenell, L.A., B.W. McMaster, and K.M. Desmarais. 1995. Evaluation of Cross Borehole Tests at Selected Wells in the Maynardville Limestone and Copper Ridge Dolomite at the Oak Ridge Y-12 Plant. Prepared for Lockheed Martin Energy Systems, Inc.(Y/TS-1166).

Solomon, D.K., G.K. Moore, L.E. Toran, R.B. Dreier, and W.M. McMaster. 1992. Status Report A Hydrologic Framework for the Oak Ridge Reservation. Oak Ridge National Laboratory (ORNL/TM-12053).

Turner, R.R., M.A. Bogel, R.B. Clapp, K.C. Dearstone, R.B. Drier, T.O. Early, S.E. Herbes, J.M. Loar, P.D. Parr, and G.R. Southworth. 1991. Remedial Investigation Work Plan for Bear Creek (Y02-S600) at the Oak Ridge Y-12 Plant, Oak Ridge, Tennessee. Martin Marietta Energy Systems, Inc. (ES/ER-19\&D2).

U.S. Department of Energy. 1995. Oak Ridge Reservation Site Management Plan for the Environmental Restoration Program. U.S. Department of Energy Oak Ridge Field Office (DOE/OR-1001/R4).

U.S. Department of Energy. 1997. Report on the Remedial Investigation of Bear Creek Valley at the Oak Ridge Y-12 Plant, Oak Ridge, Tennessee. Volume 1. Prepared for the U.S. Department of Energy (DOE/OR/01-1455/V1\&D2). 
U.S. Environmental Protection Agency. 1983. Methods for Chemical Analysis of Water and Wastes.

U.S. Environmental Protection Agency. 1986. Test Methods for Evaluating Solid Waste Physical/Chemical Methods.

Wilson, B.H., J.T. Wilson, and D. Luce. 1996. Design and Interpretation of Microcosm Studies for Chlorinated Compounds. Reported in: Symposium on Natural Attenuation of Chlorinated Organics in Ground Water. U.S. Environmental Protection Agency, Office of Research and Development (EPA/540/R-96/509). 
APPENDLX A

FIGURES 


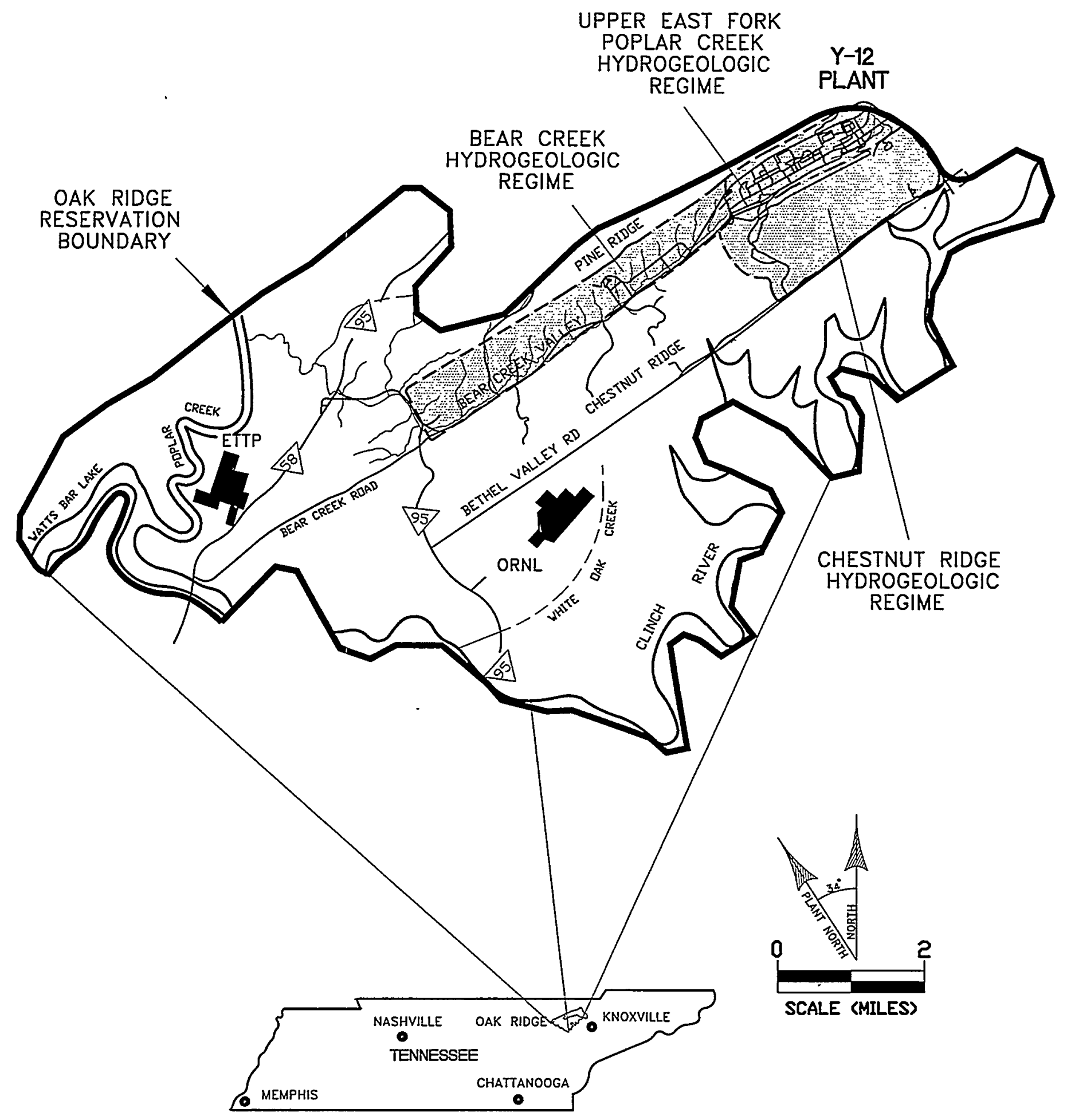




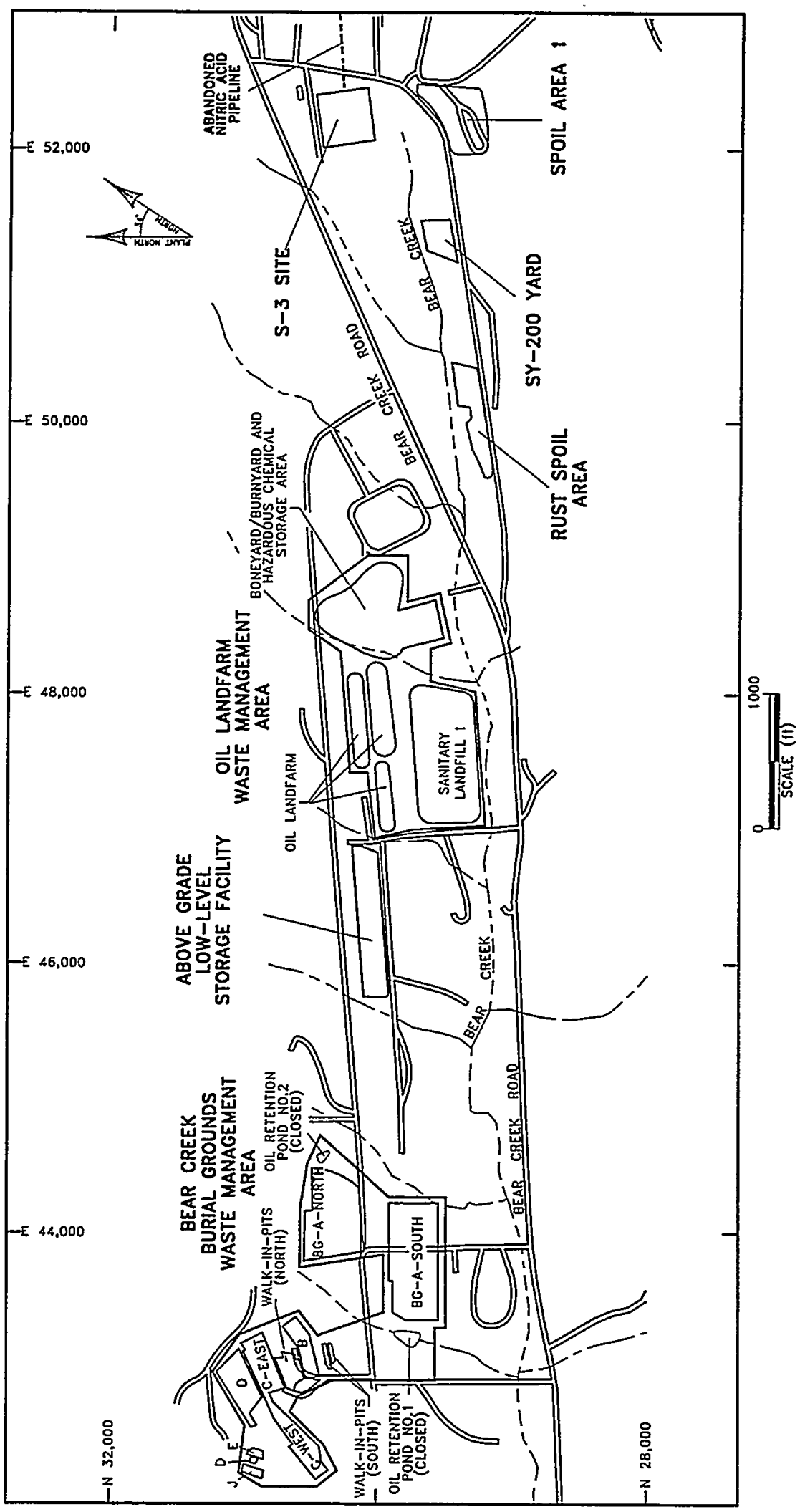




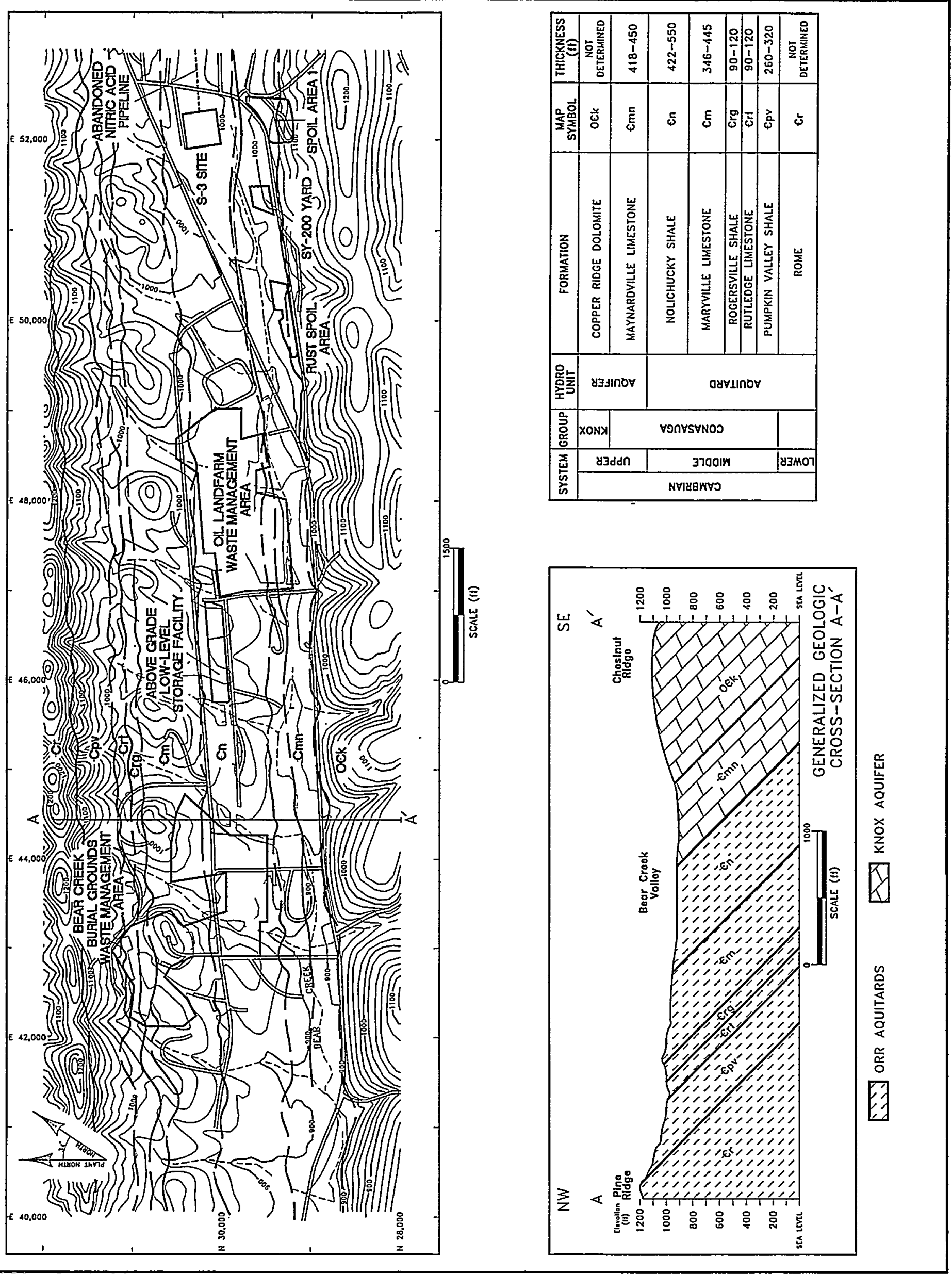

$96-090 \quad 8-10-99$

Fig. 3. Topography and bedrock geology

in the Bear Creek Hydrogeologic Regime. 


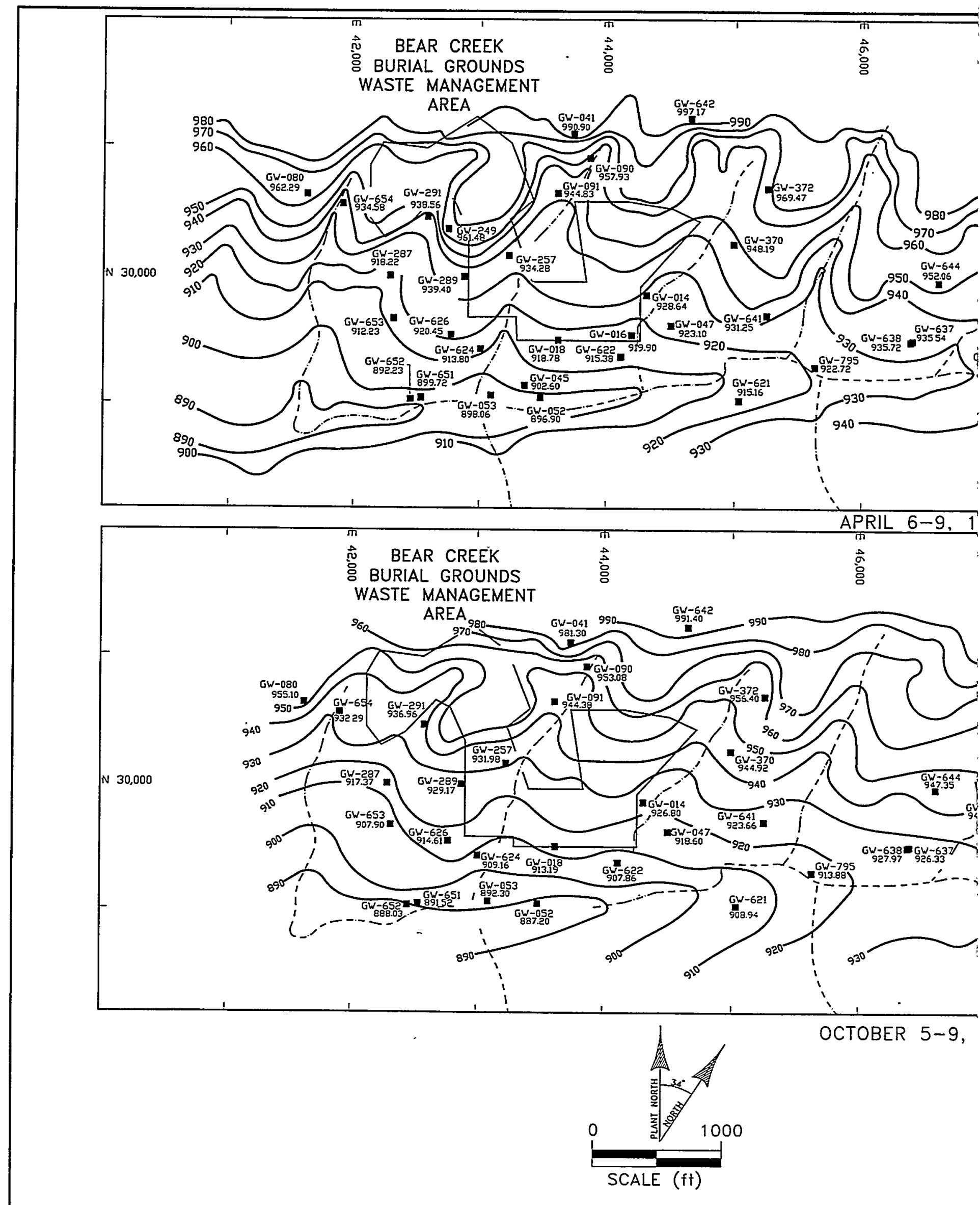




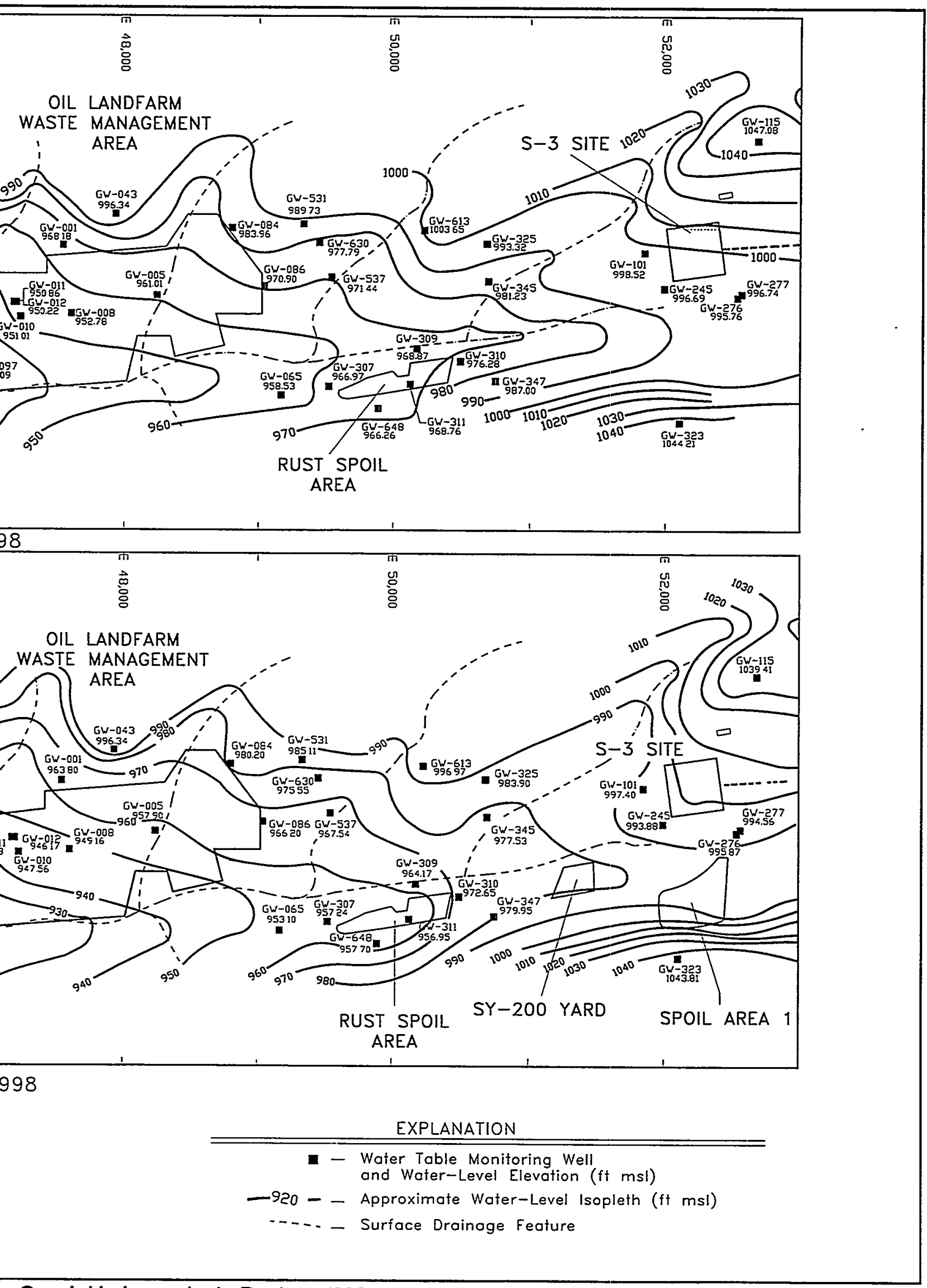



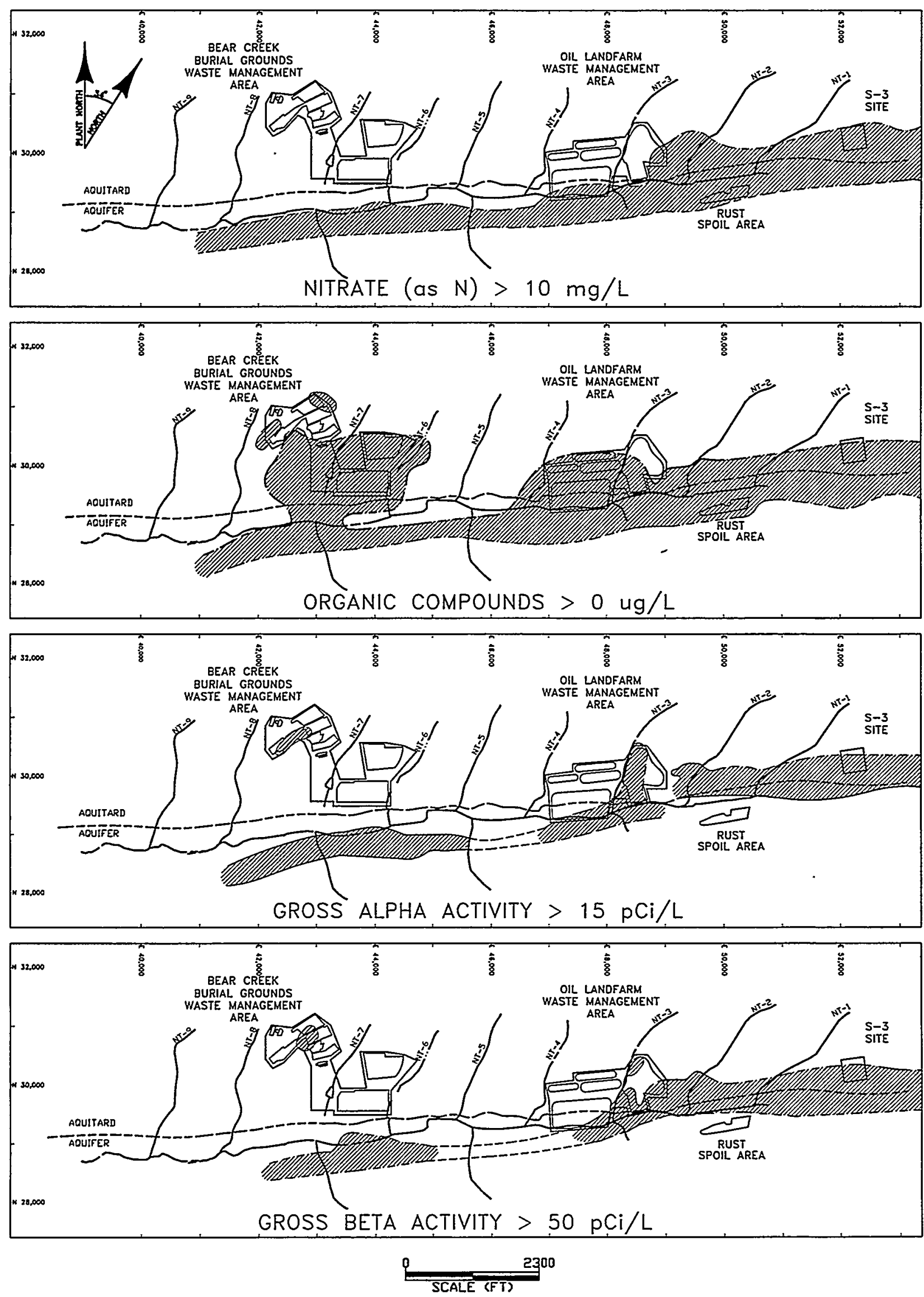


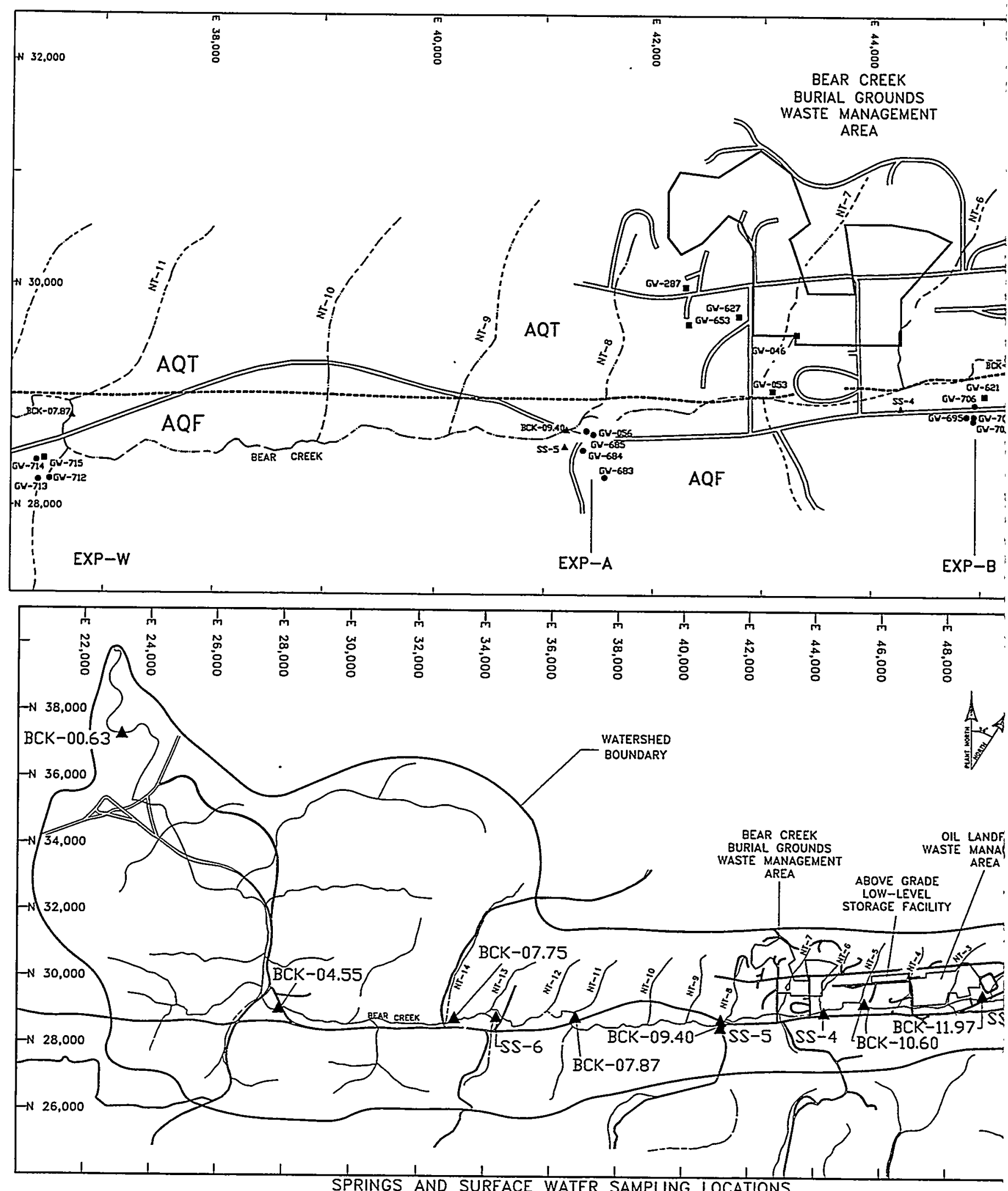

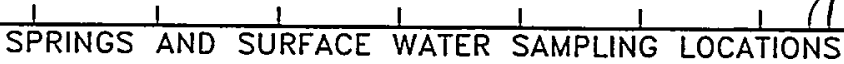

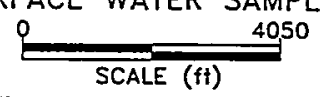




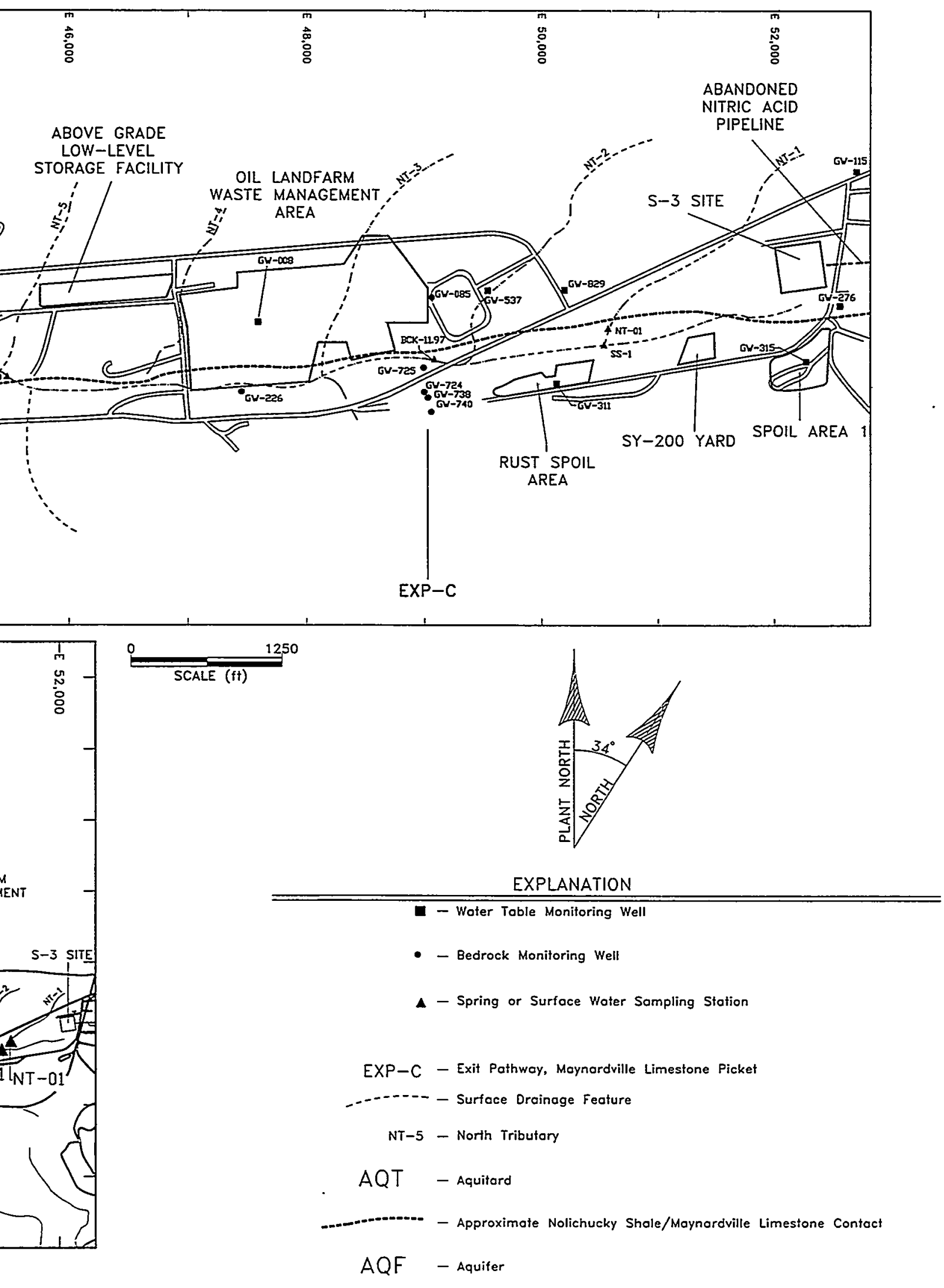




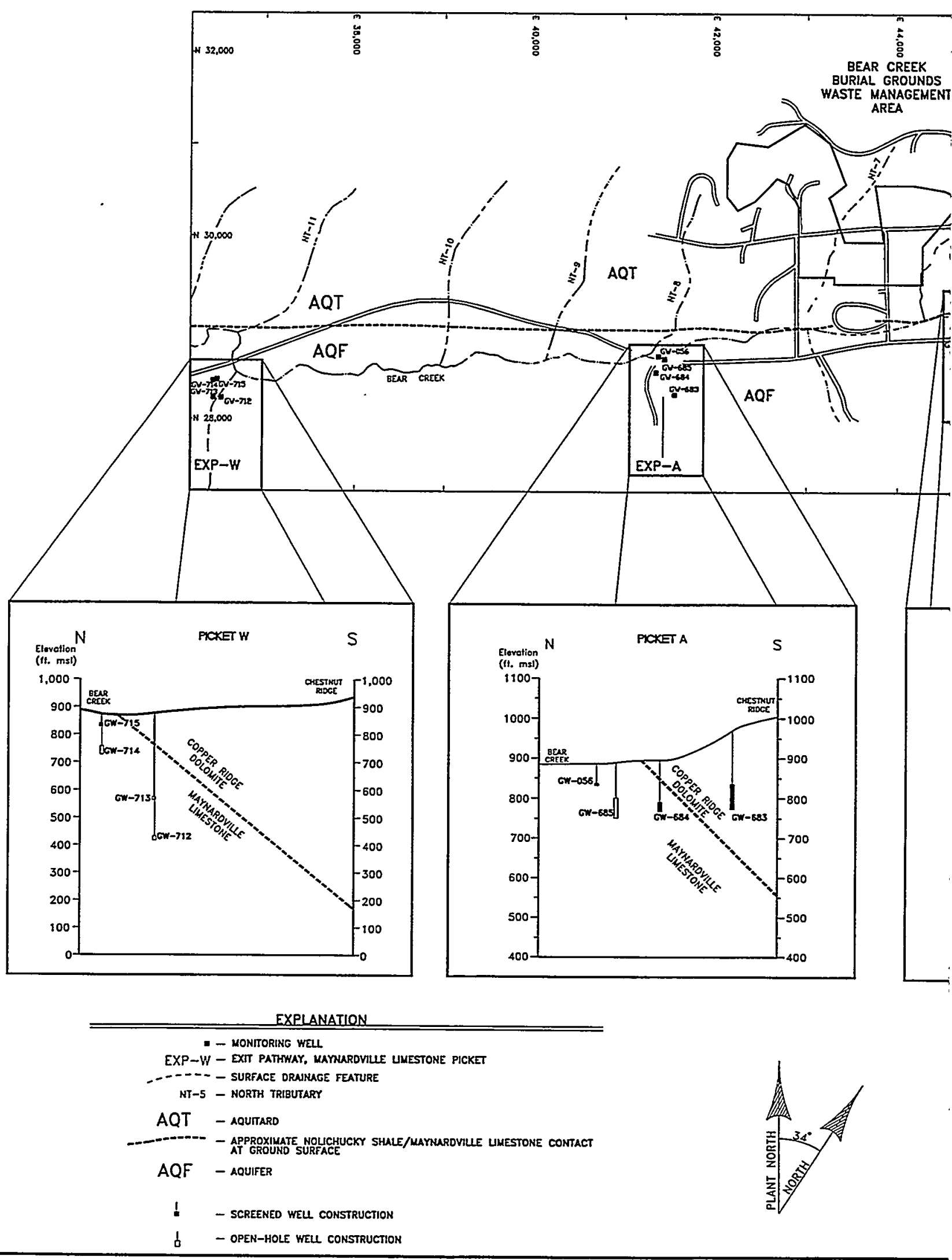




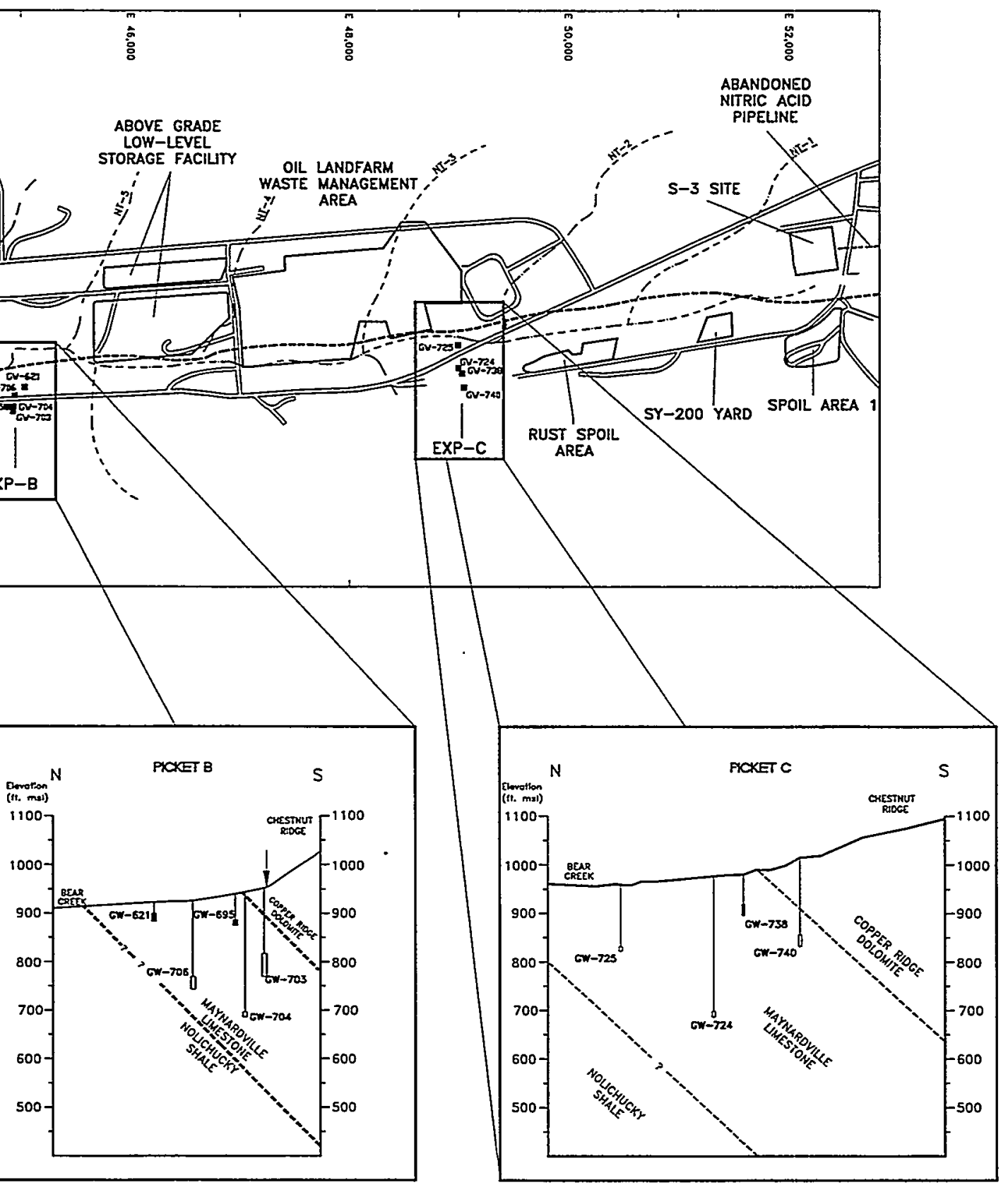

\section{e Limestone and $W$.}




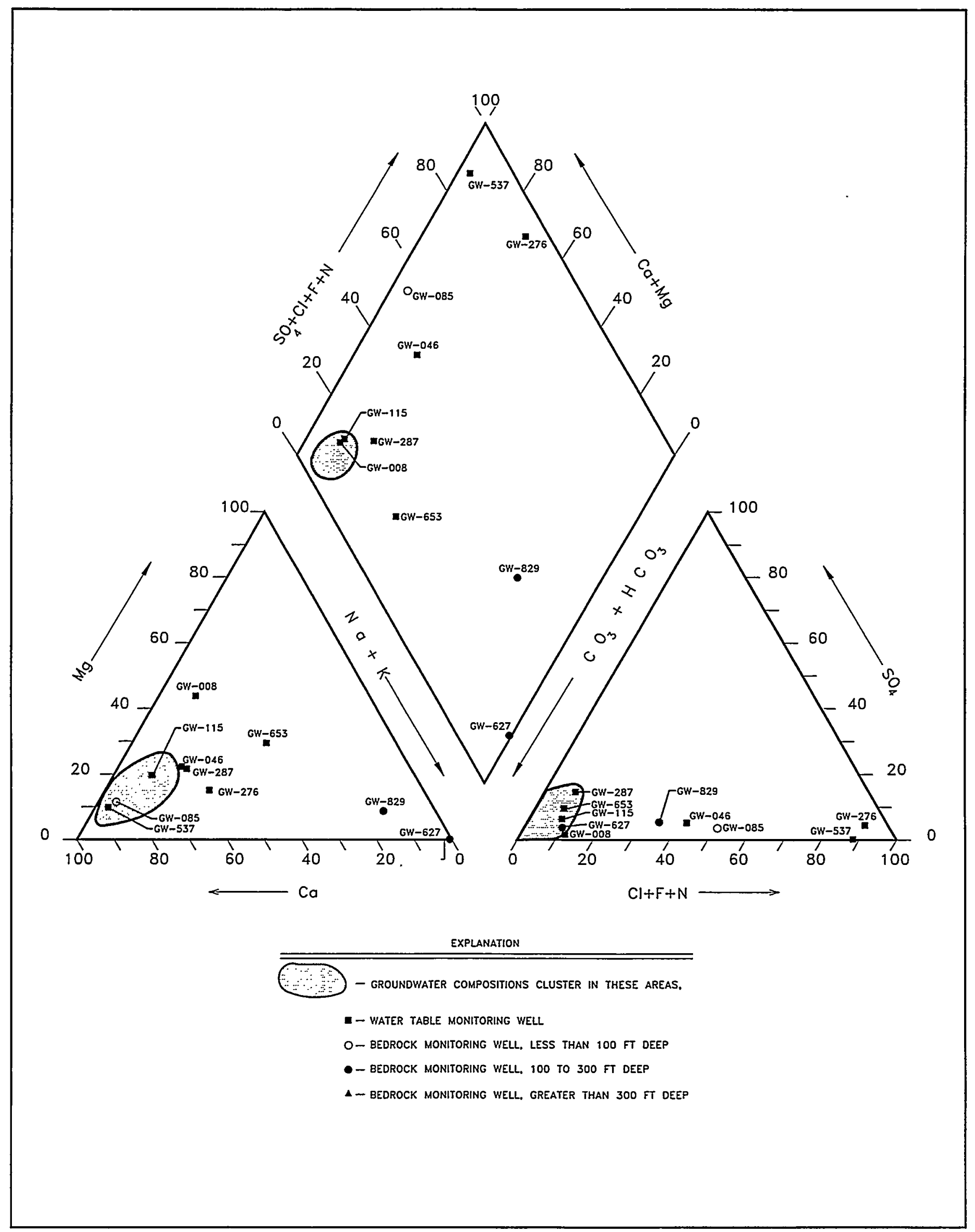



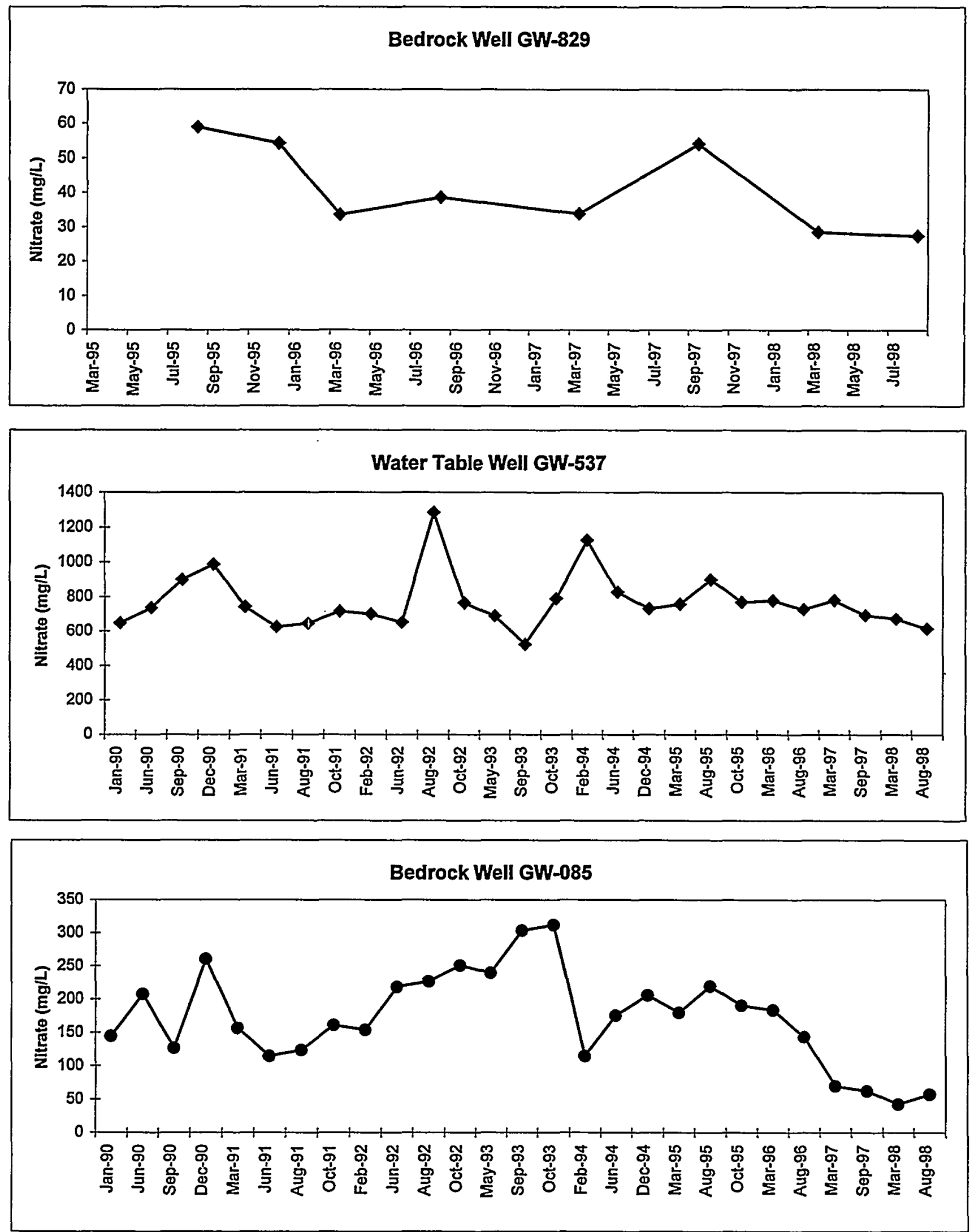

Notes: Nitrate $\mathrm{MCL}=10 \mathrm{mg} / \mathrm{L}$

$$
\begin{array}{rrr}
\text { Anomalous Results omitted: } & \text { GW-829 } & 2,210 \mathrm{mg} / \mathrm{L} \text { (Mar-95), } 200 \mathrm{mg} / \mathrm{L} \text { (Jun-95) } \\
& \text { GW-537 } & 81 \mathrm{mg} / \mathrm{L} \text { (Sept-94) } \\
& \text { GW-085 } & 2,139 \mathrm{mg} / \mathrm{L} \text { (Feb-93), } 17 \mathrm{mg} / \mathrm{L} \text { (Jun-95) }
\end{array}
$$

Fig. 9. Nitrate concentration trends in Aquitard wells GW-085, GW-537, and GW-829. 


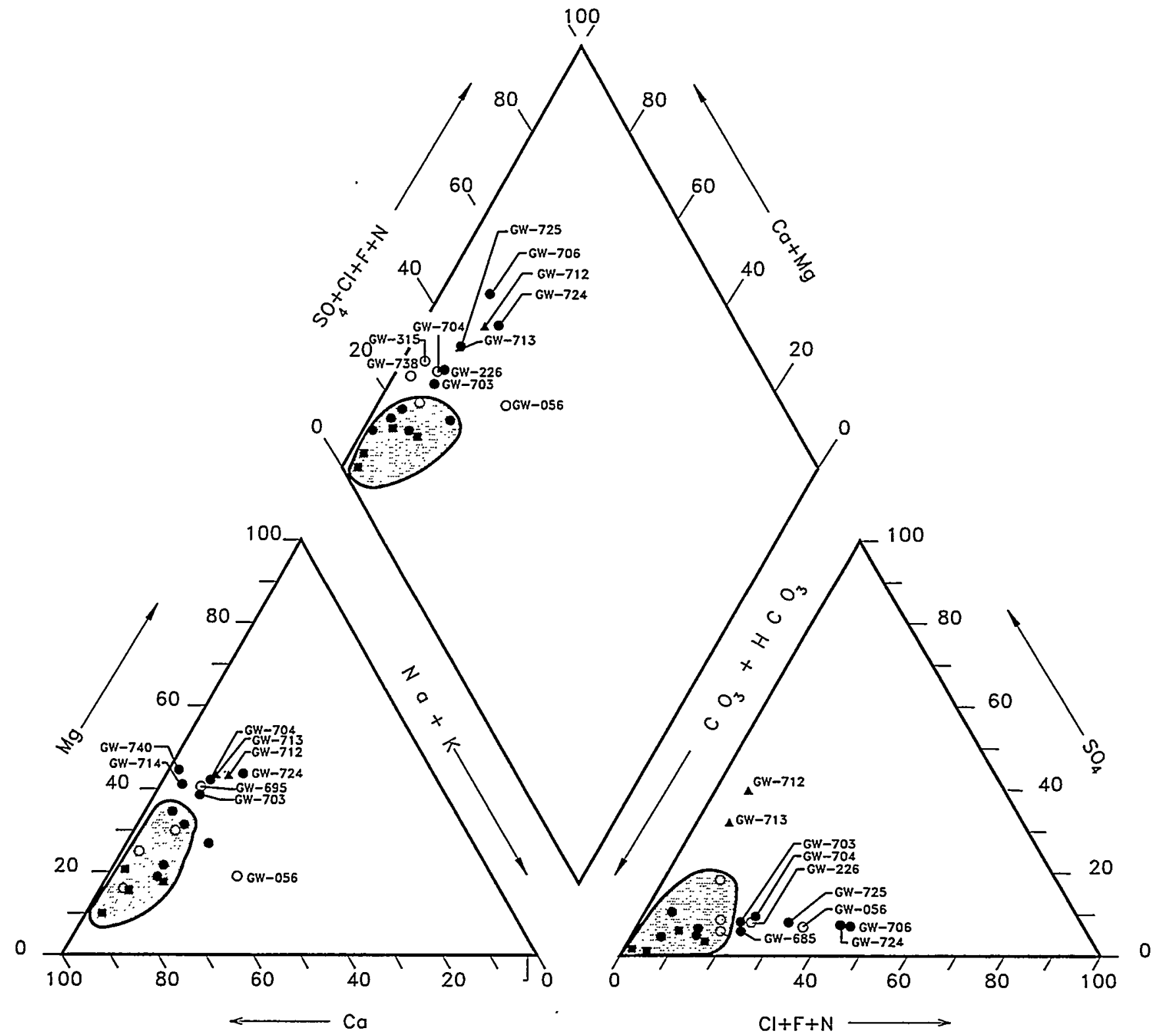

EXPLANATION

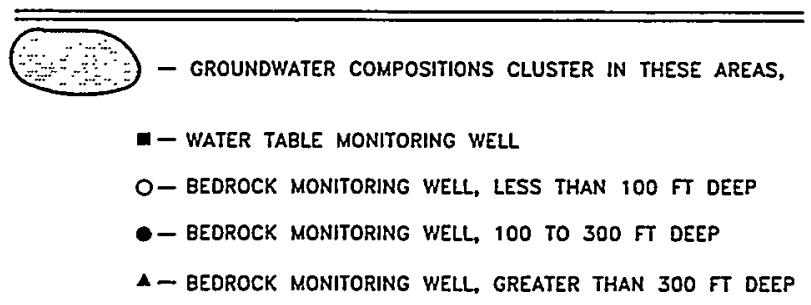



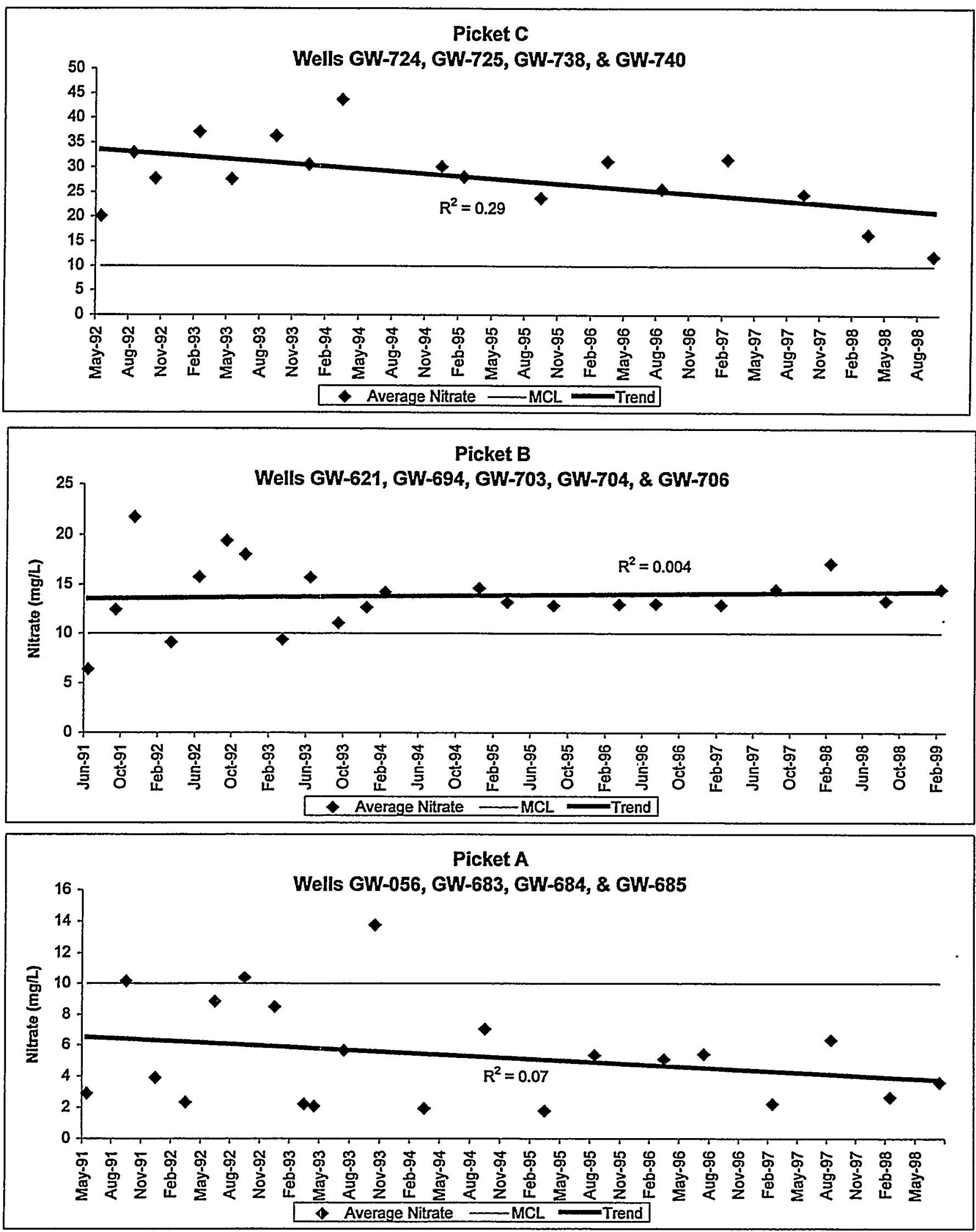

Note: Nitrate $=$ average concentration calculated from data for all the listed wells during each sampling event.

Fig. 11. Long-term average nitrate concentration trends in the Aquifer. 

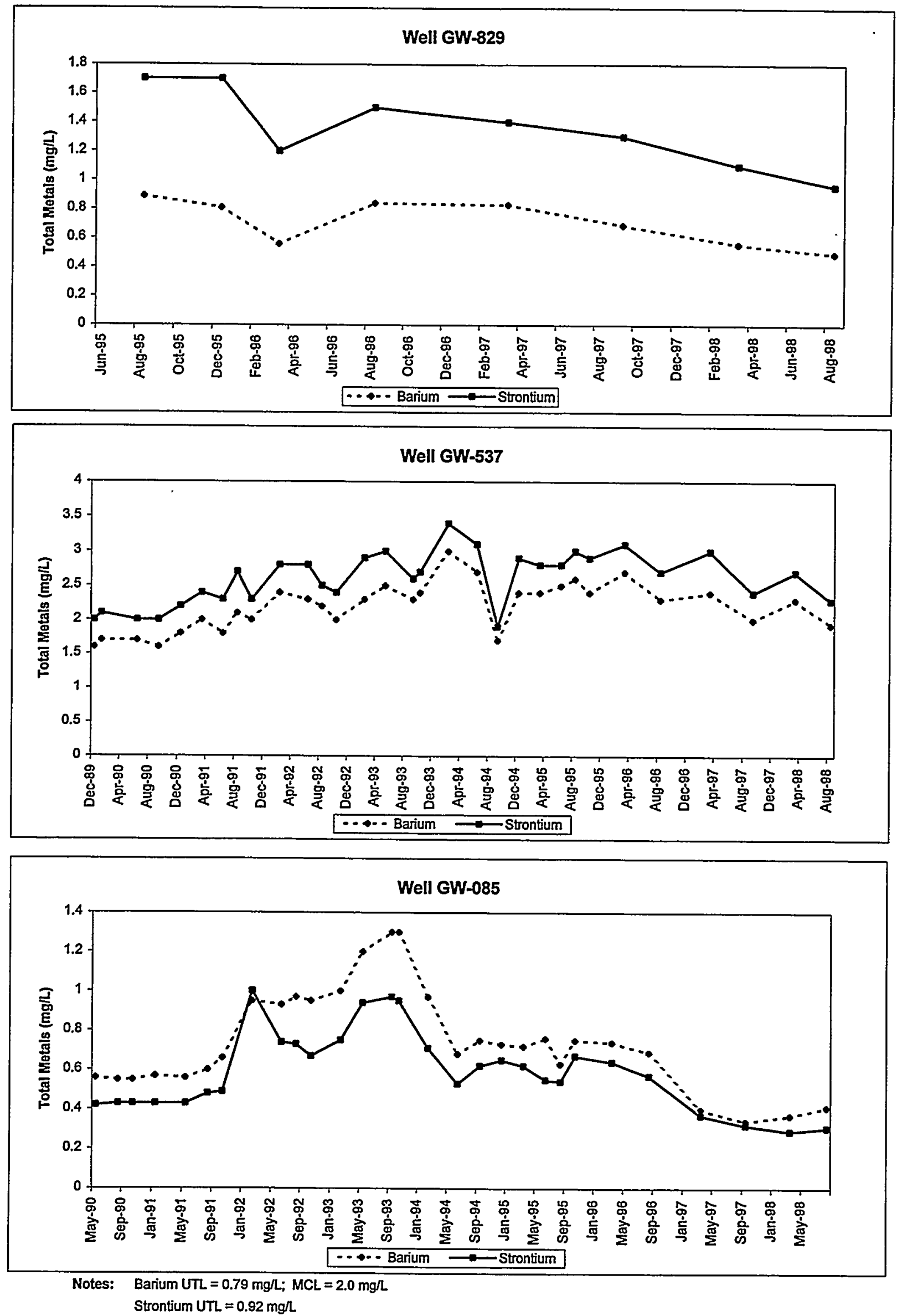

Fig. 12. Barium and strontium concentration trends in Aquitard wells GW-085, GW-537, and GW-829. 

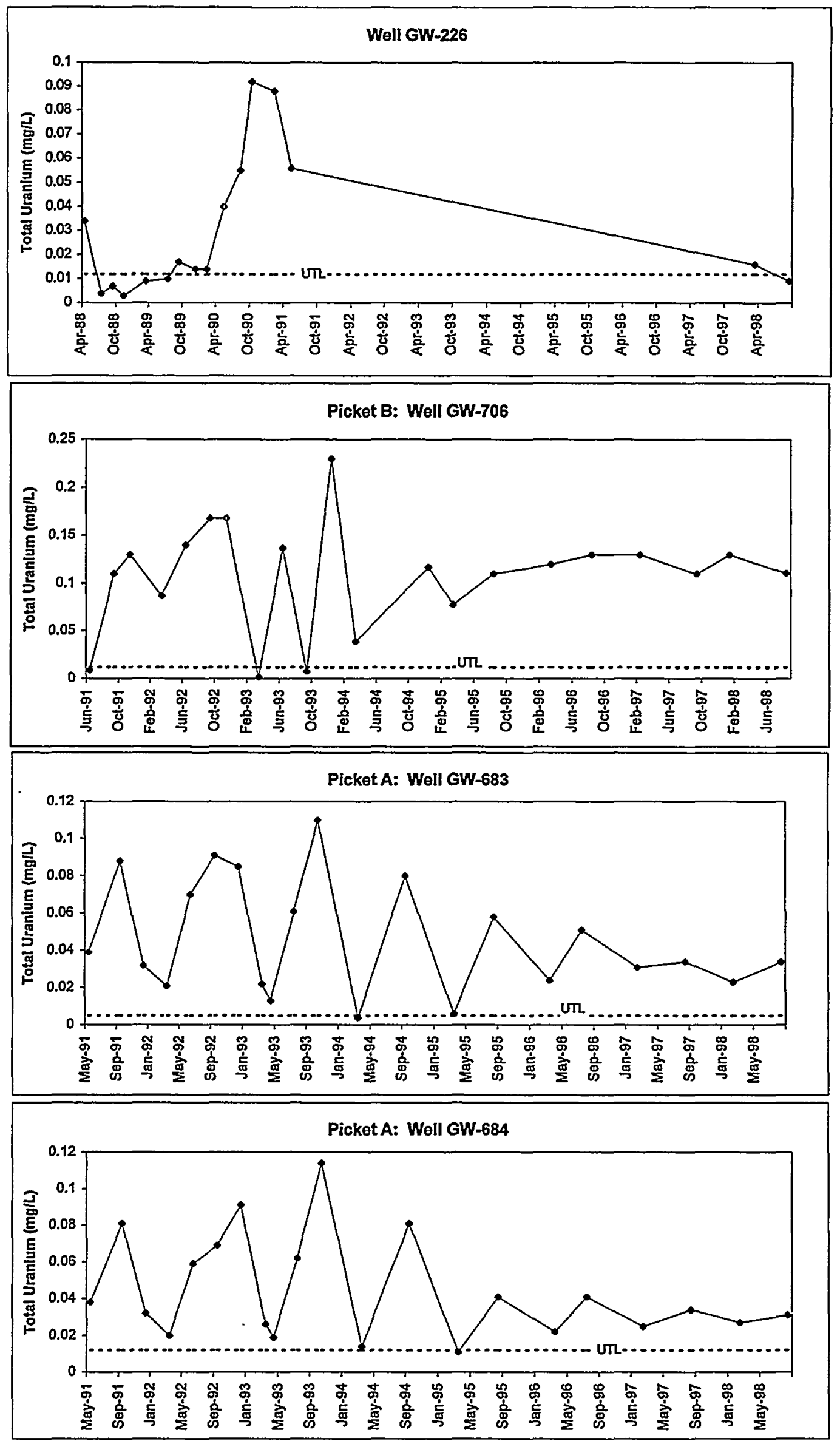

Fig. 13. Uranium concentration trends in Aquifer wells GW-226, GW-683, GW-684, and GW-706. 

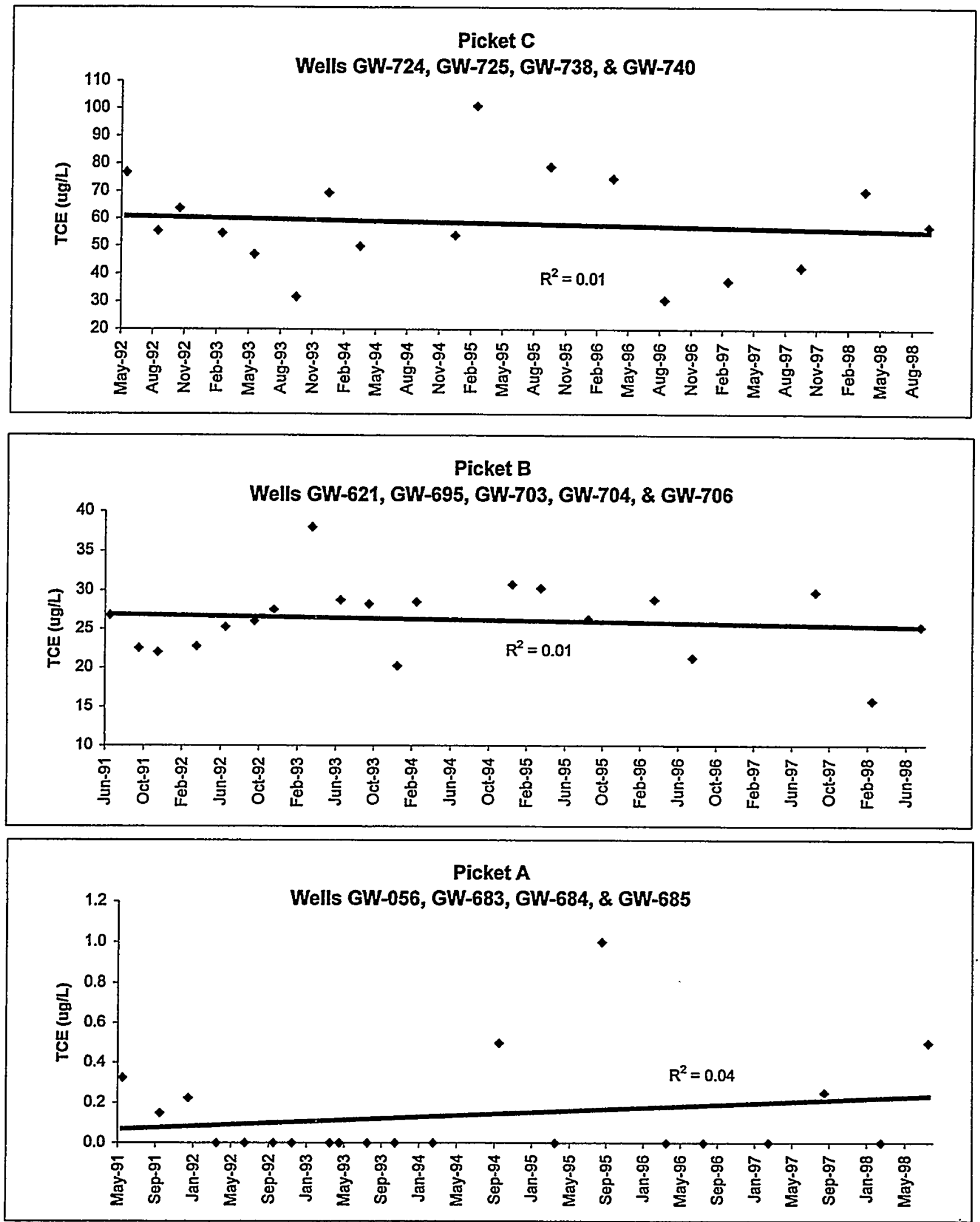

Note: Trichloroethene $=$ average concentration calculated from data for all the listed wells during each sampling event.

Fig. 14. Long-term average TCE concentration trends in the Aquifer. 

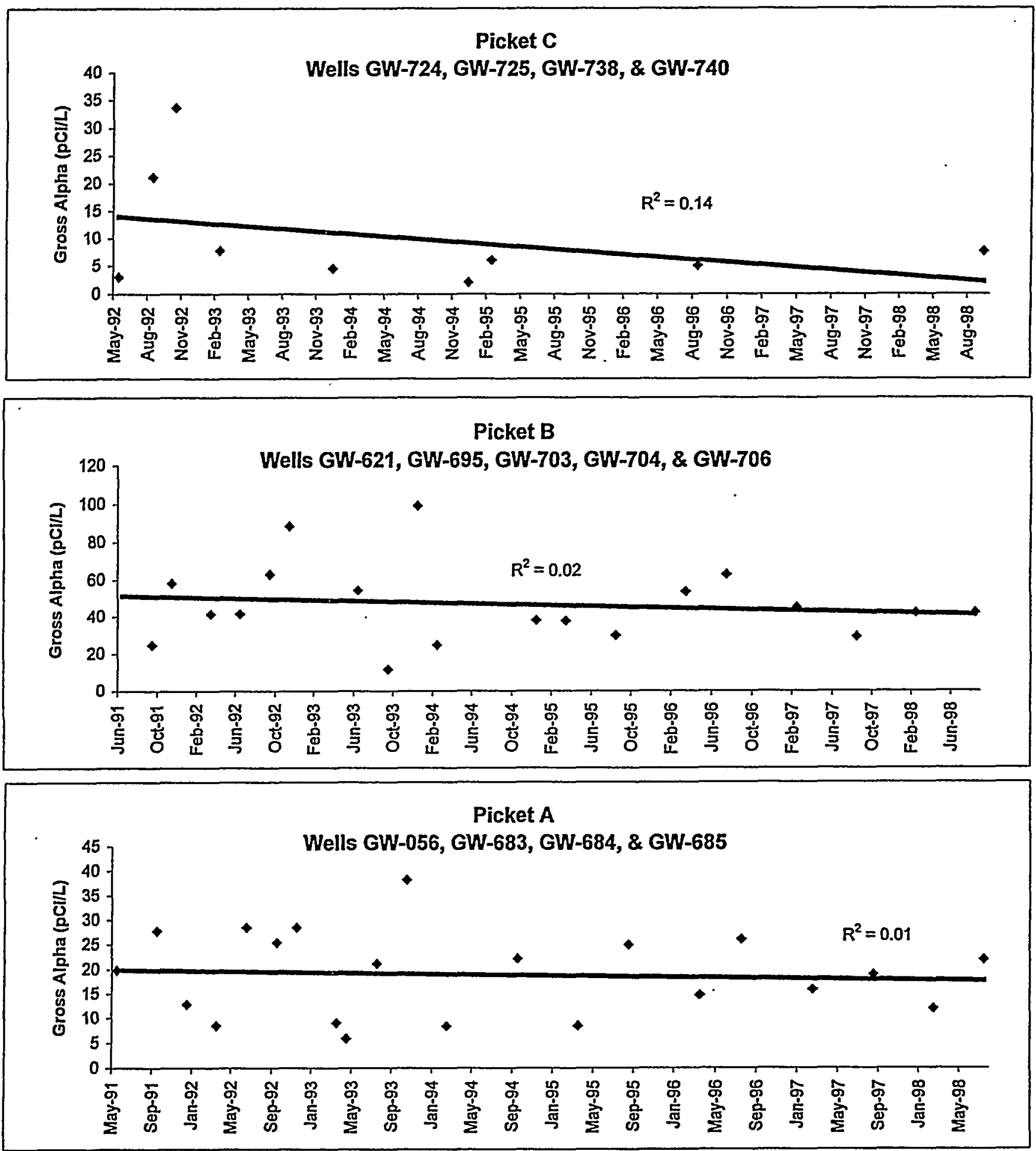

Note: Alpha = maximum gross alpha activity reported for the listed wells during each sampling event.

Fig. 15. Long-term gross alpha activity trends in the Aquifer. 

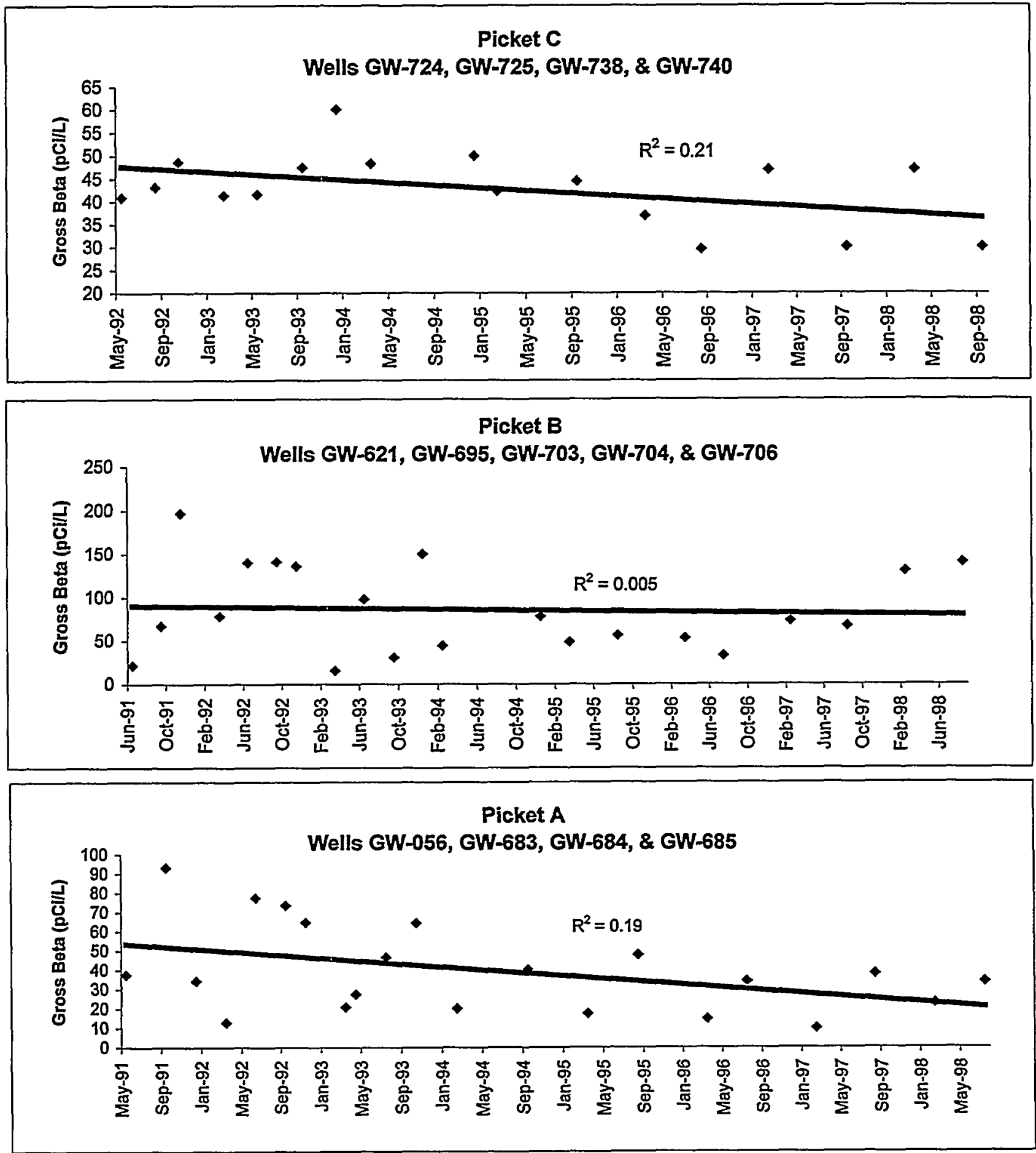

Note: Gross Beta $=$ maximum gross beta activity reported for the listed wells during each sampling event.

Fig. 16. Long-term gross beta activity trends in the Aquifer. 


\section{BCK-11.97}
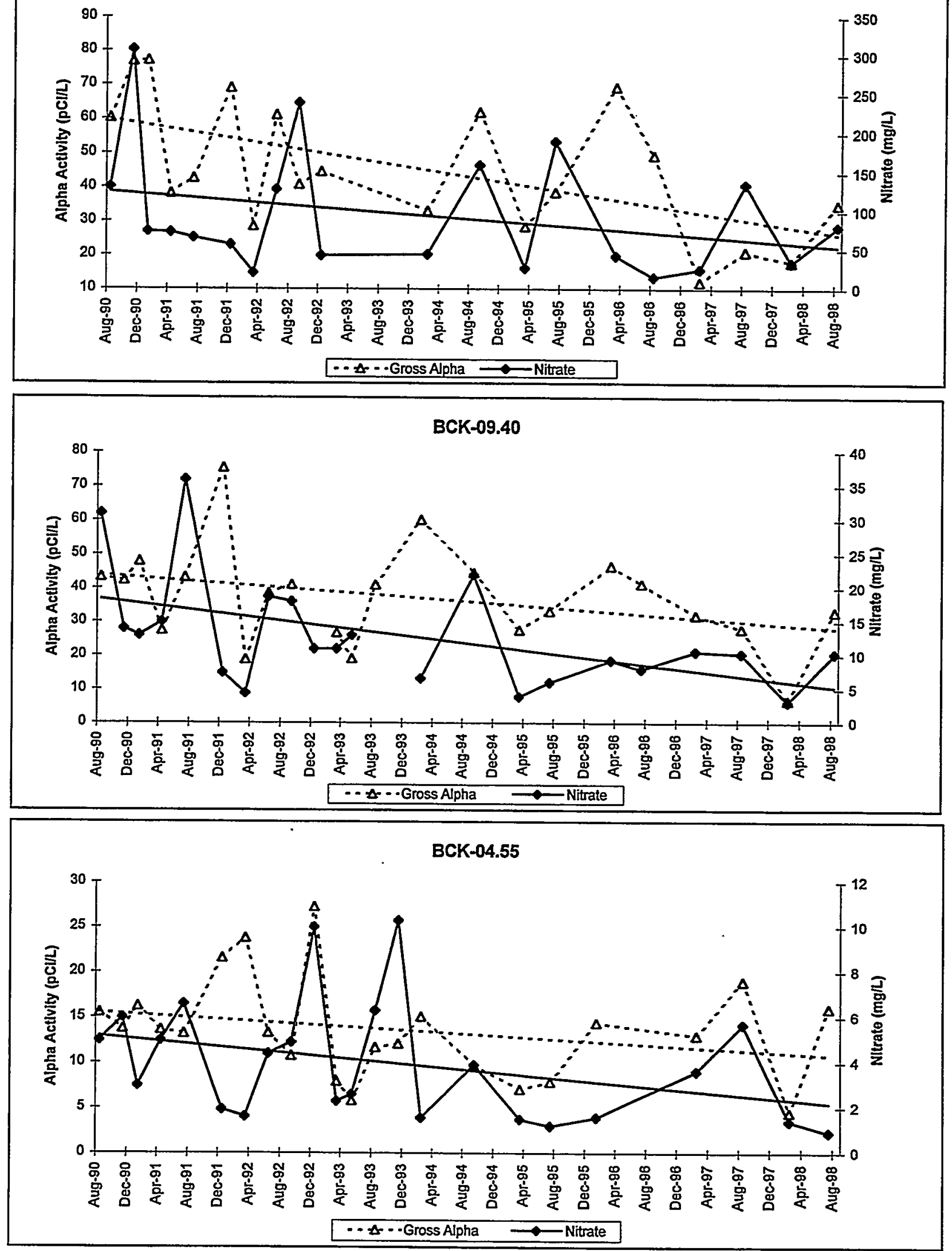

Notes: Nondected and anomalously high results are not plotted.

Gross Alpha $M C L=15 \mathrm{pCi} /$; Nitrate $M C L=10 \mathrm{mg} /$.

Fig. 17. Nitrate concentrations and gross alpha activity trends in Bear Creek. 


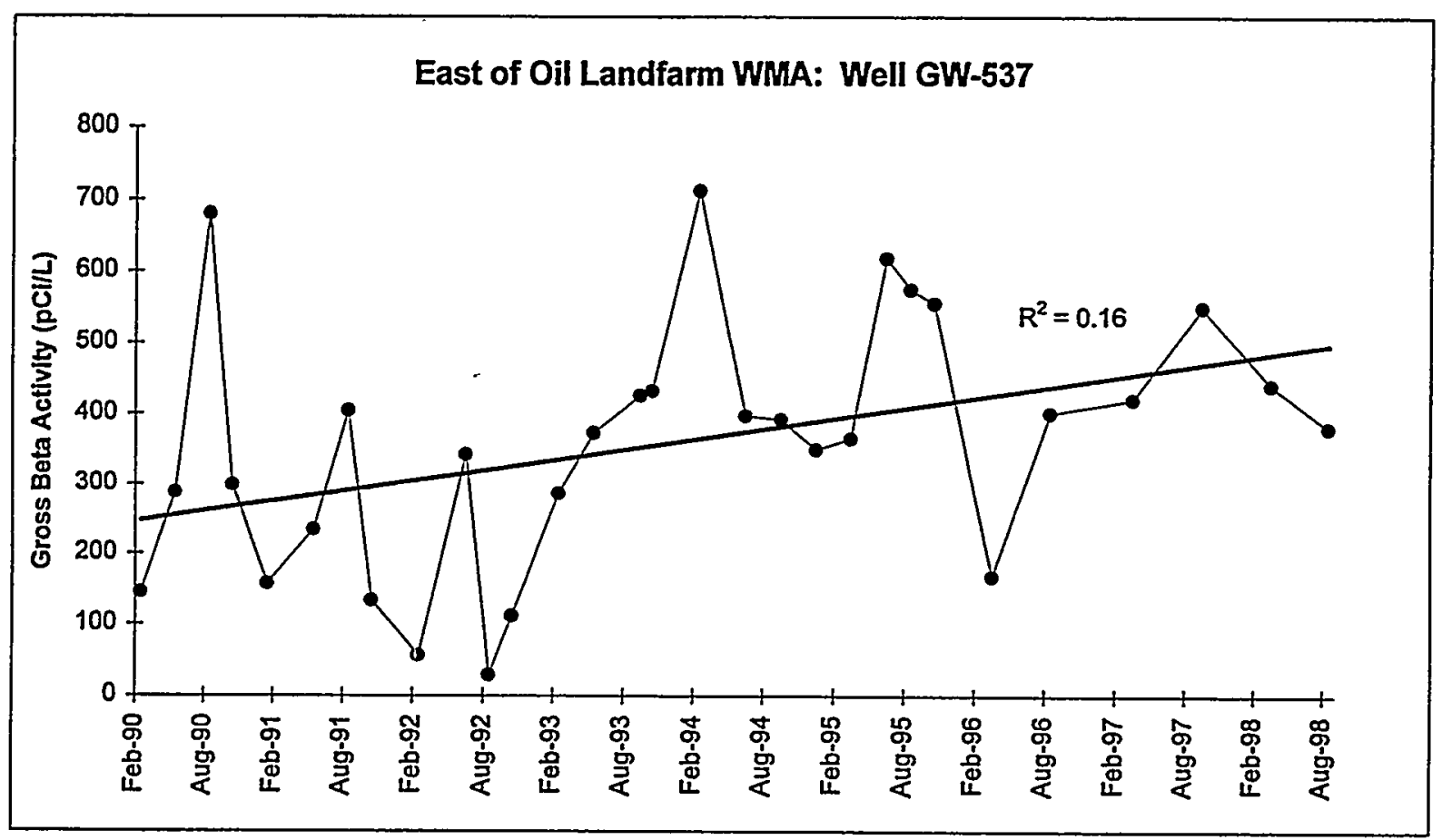

Fig. 18. Gross beta activity trend in Aquitard well GW-537. 

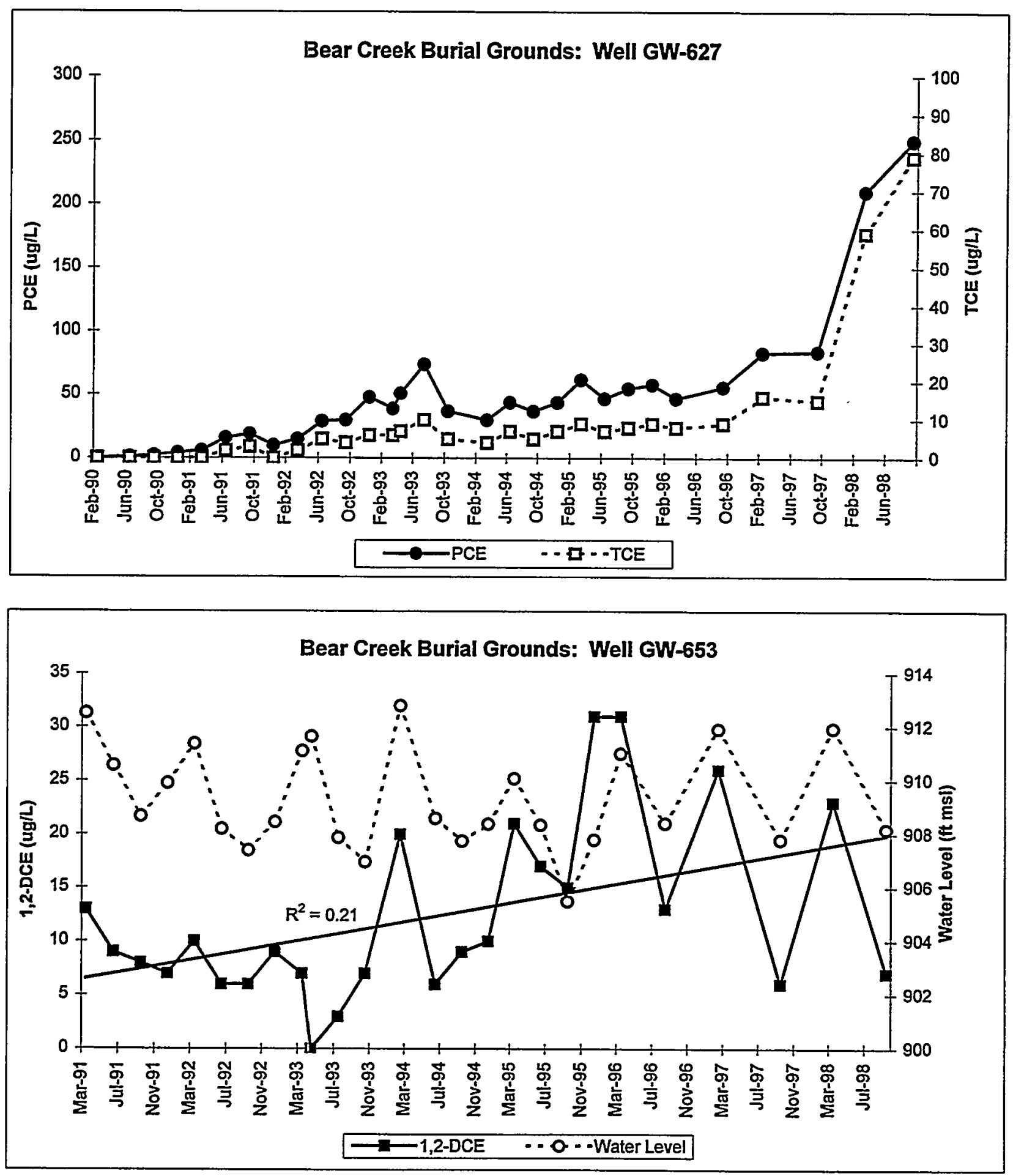

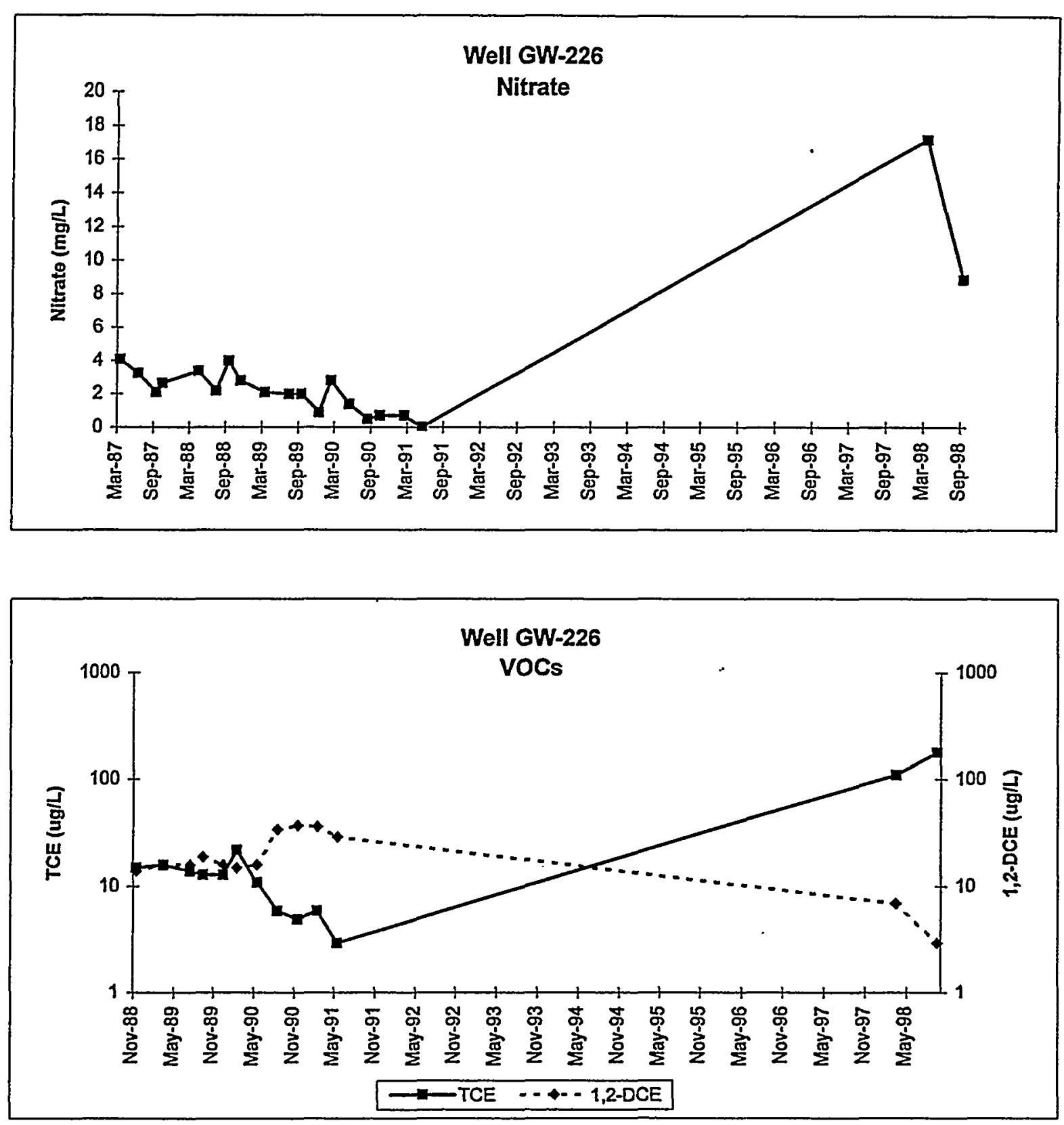

Fig. 20. Nitrate, TCE, and 1,2-DCE concentration trends in Aquifer well GW-226. 

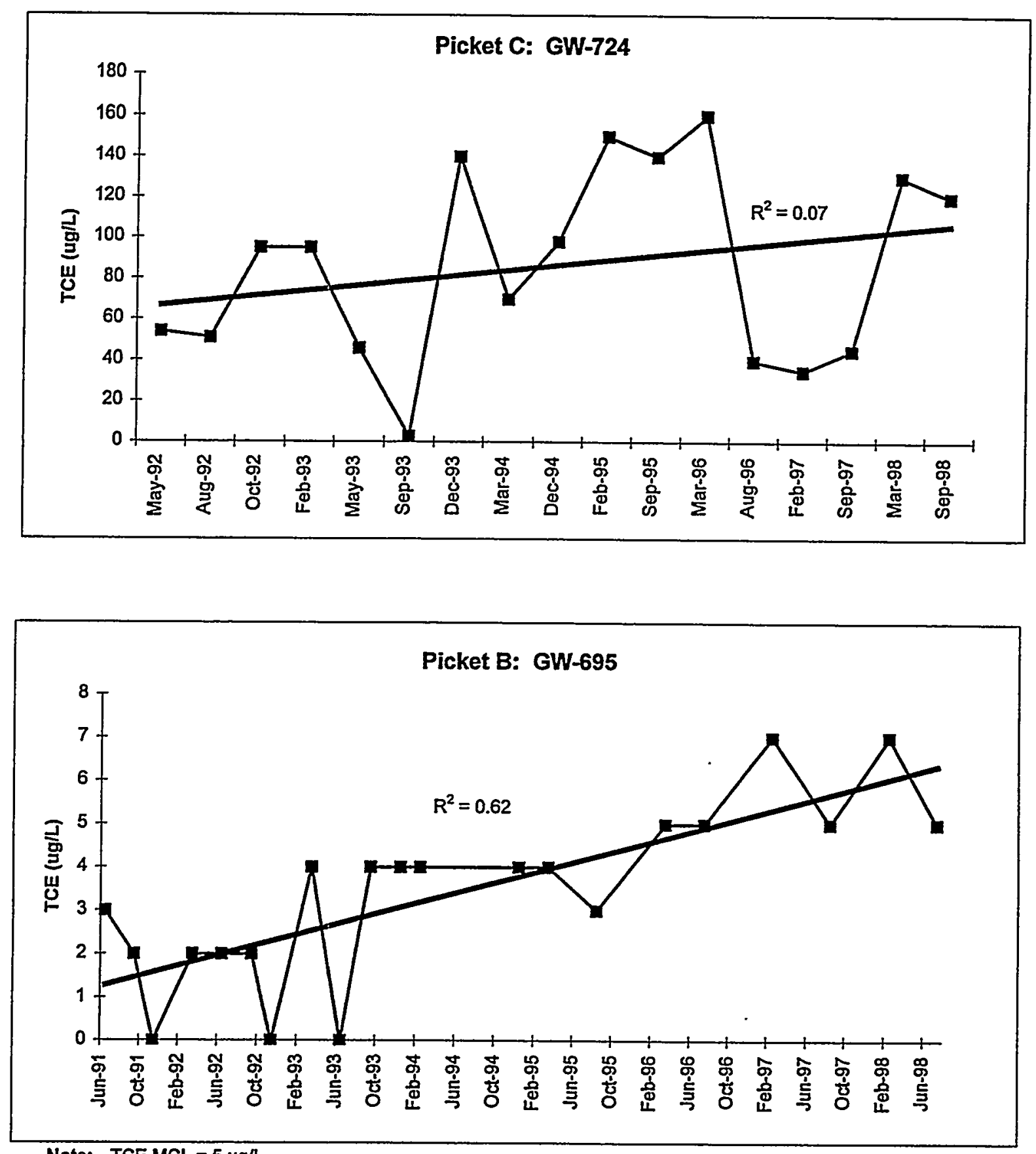

Note: TCE MCL $=5$ ug $/$

Fig. 21. TCE concentration trends in Aquifer wells GW-695 and GW-724. 

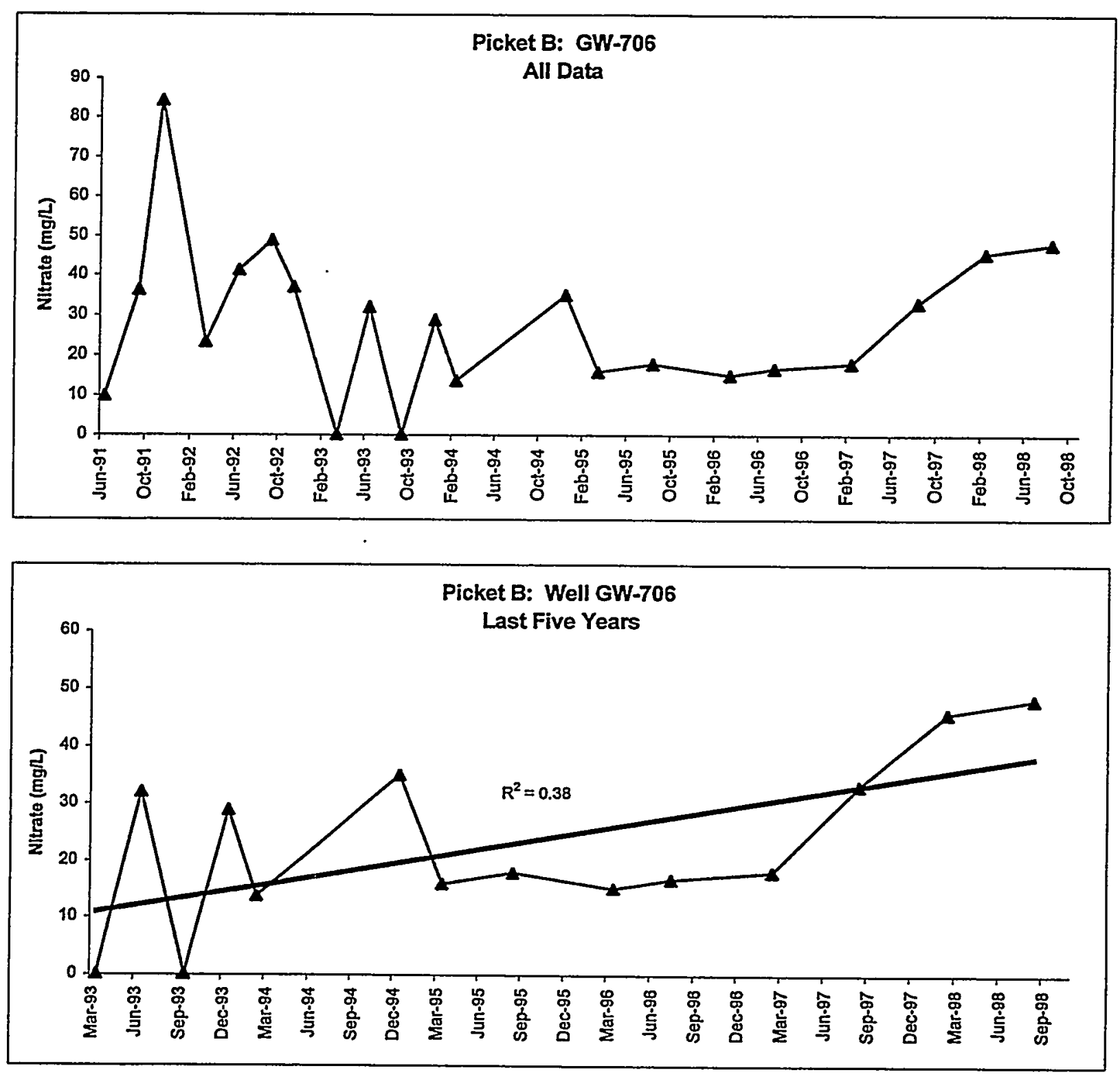

Fig. 22. Nitrate concentration trend in Aquifer well GW-706.

\section{A-22}




\section{APPENDIX B}

TABLES 
Table 1. Waste management sites and regulated units in the Bear Creek Hydrogeologic Regime.

\begin{tabular}{|c|c|c|c|c|}
\hline \multirow{2}{*}{$\begin{array}{l}\text { Waste Management Site/ } \\
\text { Regulated Unit }\end{array}$} & \multirow{2}{*}{$\begin{array}{c}\text { Regulatory } \\
\text { Classification }^{1}\end{array}$} & \multirow[t]{2}{*}{ General Waste Inventory } & \multicolumn{2}{|c|}{ Operational Status } \\
\hline & & & Closed & Active \\
\hline $\begin{array}{l}\text { Above Grade Low-Level } \\
\text { Storage Facility }\end{array}$ & NR & $\begin{array}{l}\text { Low-level radioactive construction } \\
\text { and demolition wastes. }\end{array}$ & & - \\
\hline $\begin{array}{l}\text { Boneyard, Burnyard, and } \\
\text { Hazardous Chemical Disposal } \\
\text { Area }\end{array}$ & CERCLA & $\begin{array}{l}\text { Magnesium chips, construction } \\
\text { debris, pesticide containers, metal } \\
\text { shavings, solvents, oils, laboratory } \\
\text { chemicals, acids, bases, organics, } \\
\text { water-reactive compounds, and } \\
\text { shock sensitive compounds. }\end{array}$ & - & \\
\hline $\begin{array}{l}\text { Burial Grounds A (North and } \\
\text { South) }\end{array}$ & $\begin{array}{c}\text { RCRA/ } \\
\text { CERCLA }\end{array}$ & $\begin{array}{l}\text { Waste oils, coolants, and spent } \\
\text { solvents. }\end{array}$ & - & \\
\hline Burial Grounds C (West) & $\begin{array}{l}\text { RCRA/ } \\
\text { CERCLA } \\
\end{array}$ & $\begin{array}{l}\text { Waste oils, coolants, and spent } \\
\text { solvents. }\end{array}$ & - & \\
\hline Burial Grounds B, D, E, and J & $\overline{\text { CERCLA }}$ & $\begin{array}{l}\text { Solid wastes including salts, metals } \\
\text { (beryllium and uranium) and metal } \\
\text { oxides, metal saw fines, and } \\
\text { asbestos. }\end{array}$ & - & \\
\hline Oil Landfarm & $\begin{array}{l}\text { RCRA } \\
\text { CERCLA }\end{array}$ & $\begin{array}{l}\text { Waste oils and coolants containing } \\
\text { beryllium compounds, depleted } \\
\text { uranium, polychlorinated } \\
\text { biphenyls, and spent solvents. }\end{array}$ & - & \\
\hline Oil Retention Pond No. 1 & CERCLA & $\begin{array}{l}\text { Oil seepage from Burial Ground A } \\
\text { South. }\end{array}$ & - & \\
\hline Oil Retention Pond No. 2 & CERCLA & $\begin{array}{l}\text { Oil seepage from Burial Ground A } \\
\text { North. }\end{array}$ & - & \\
\hline Receptor Media & CERCLA & $\begin{array}{l}\text { Contaminated groundwater, surface } \\
\text { water, Bear Creek stream } \\
\text { sediments, and Bear Creek } \\
\text { floodplain soils. }\end{array}$ & \multicolumn{2}{|c|}{$\begin{array}{c}\text { Not } \\
\text { Applicable }\end{array}$} \\
\hline Rust Spoil Area & CERCLA & Nonradioactive construction debris. & 으 & \\
\hline Sanitary Landfill I & CERCLA & Nonhazardous solid wastes. & - & \\
\hline Spoil Area I & CERCLA & Nonradioactive construction debris. & - & \\
\hline SY-200 Yard & CERCLA & $\begin{array}{l}\text { Temporary storage of equipment, } \\
\text { machinery, and miscellaneous } \\
\text { items. }\end{array}$ & - & \\
\hline S-3 Site & $\begin{array}{l}\text { RCRA } \\
\text { CERCLA } \\
\end{array}$ & $\begin{array}{l}\text { Liquid, radioactive, nitric acid } \\
\text { wastes and denitrification products. }\end{array}$ & - & \\
\hline Walk-In Pits & $\begin{array}{l}\text { RCRA/ } \\
\text { CERCLA }\end{array}$ & $\begin{array}{l}\text { Chemical wastes, shock-sensitive } \\
\text { reagents, and uranium metal saw } \\
\text { fines. }\end{array}$ & - & \\
\hline
\end{tabular}




\section{Table 1 (continued)}

\section{Notes:}

1 From: U.S. Department of Energy. 1995. Oak Ridge Reservation Site Management Plan for the Environmental Restoration Program. U.S. Department of Energy Oak Ridge Field Office (DOE/OR-1001/R4). This classification applies only to CERCLA and RCRA regulations and may not reflect other applicable regulations (e.g., solid waste regulations at Spoil Area I).

CERCLA - Comprehensive Environmental Response, Compensation, and Liability Act

RCRA - Resource Conservation and Recovery Act

NR - Not regulated under RCRA or CERCLA. 
Table 2. CY 1998 groundwater and surface water sampling locations and dates

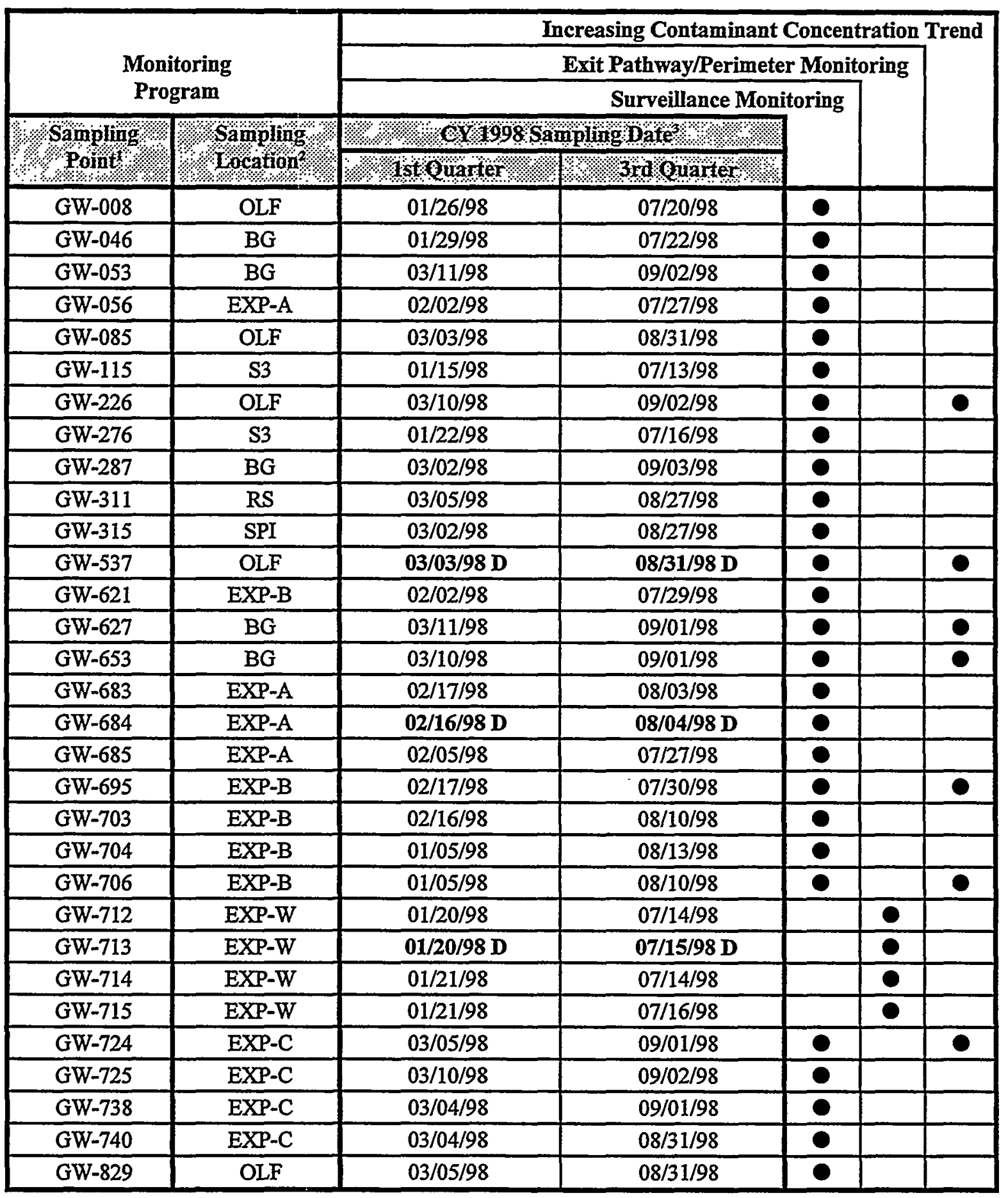


Table 2 (continued)

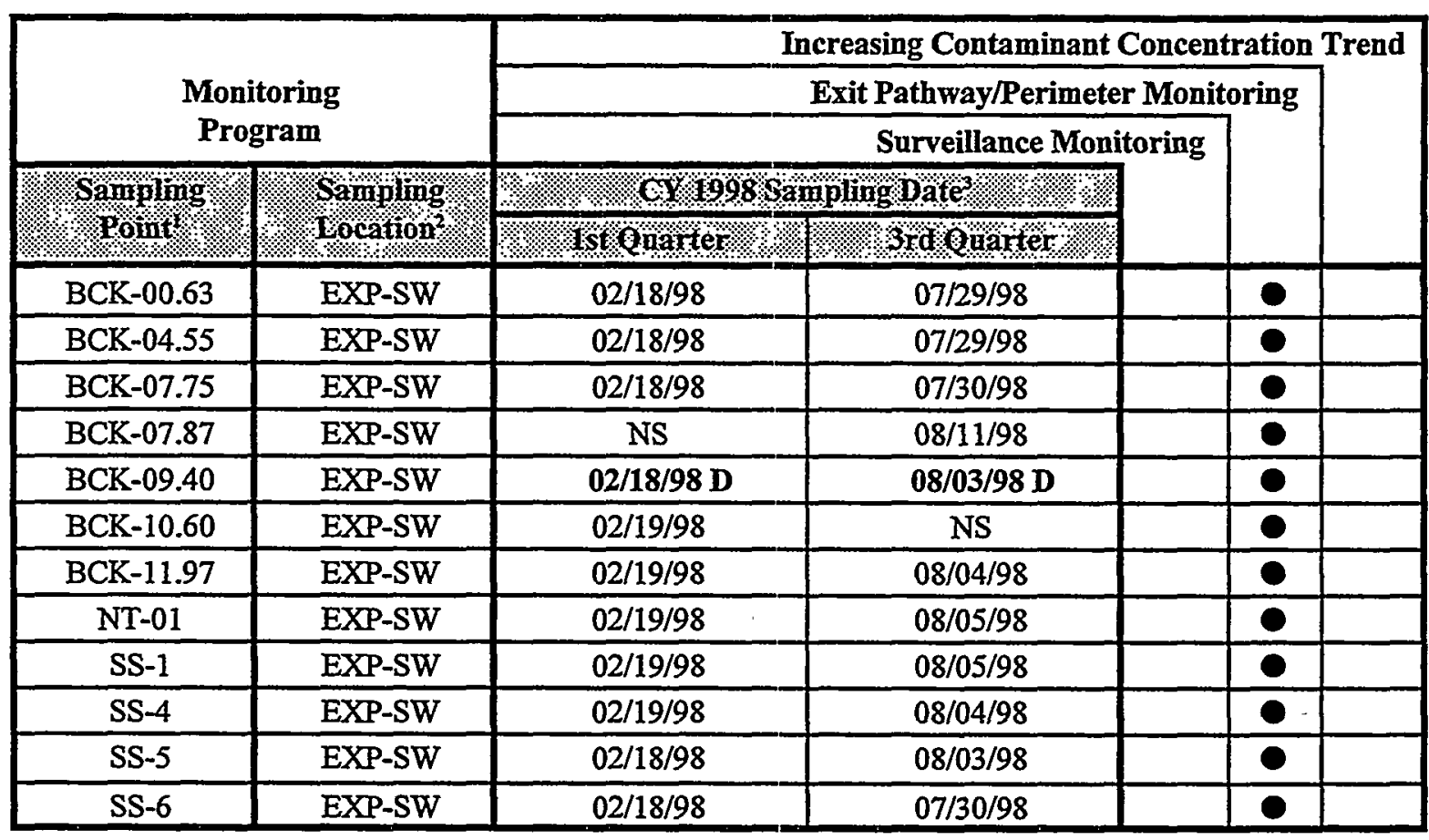

Notes:

1 BCK - Bear Creek Kilometer

GW - Groundwater Monitoring Well

NT - Northern Tributary

SS - South Spring

2 BG - Bear Creek Burial Grounds Waste Management Area

EXP-A - Exit Pathway (Maynardville Limestone) Picket A

EXP-B - Exit Pathway Picket B

EXP-C - Exit Pathway Picket C

EXP-W - Exit Pathway Picket W

EXP-SW - Exit Pathway (Bear Creek) Surface Water

OLF - Oil Landfarm Waste Management Area

RS - Rust Spoil Area

SPI - Spoil Area I

S3 - S-3 Site

3 D - Duplicate samples were collected.

NS - Not sampled; BCK-07.87 was not on the first quarter sampling schedule, and BCK-10.60 was dry during the October sampling event. 
Table 3. Field measurements and laboratory analytes for CY 1998 groundwater and surface water samples

\begin{tabular}{|c|c|c|c|}
\hline Fieldyeasurements: & AnalyicalMethod & Defection Ginit ${ }^{2}$ & Units ${ }^{3} \otimes$ \\
\hline Depth to Water & ESP 302-1 & NA & $\mathrm{ft}$ \\
\hline Water Temperature & ESP 307-1 & NA & centigrade \\
\hline $\mathrm{pH}$ & ESP 307-1 & NA & $\mathrm{pH}$ units \\
\hline Conductivity & ESP 307-1 & NA & $\mu \mathrm{mho} / \mathrm{cm}$ \\
\hline Dissolved Oxygen & ESP 307-3 & NA & $\mathrm{ppm}$ \\
\hline Oxidation-Reduction Potential & ESP 307-5 & NA & $\mathrm{mV}$ \\
\hline 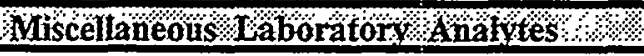 & $\%$ & ४ & \% \\
\hline $\mathrm{pH}$ & EPA-9040 & NA & pH units \\
\hline Conductivity & EPA-9050 & $\mathrm{NA}$ & $\mu \mathrm{mho} / \mathrm{cm}$ \\
\hline Total Dissolved Solids & EPA-160.1 & 1 & $\mathrm{mg} / \mathrm{L}$ \\
\hline Total Suspended Solids & EPA-160.2 & 1 & $\mathrm{mg} / \mathrm{L}$ \\
\hline Turbidity & EPA-180.1 & 0.1 & NTU \\
\hline Anions $/ \% \%$ \% \% \% \% \% & \%:\%: & ও৮\% ২ & $\%$ \\
\hline Alkalinity - $\mathrm{HCO} 3$ & EPA-310.1 & 1.0 & $\mathrm{mg} / \mathrm{L}$ \\
\hline Alkalinity - $\mathrm{CO} 3$ & EPA-310.1 & 1.0 & $\mathrm{mg} / \mathrm{L}$ \\
\hline Chloride & EPA-300.0 & 0.2 & $\mathrm{mg} / \mathrm{L}$ \\
\hline Fluoride & EPA-340.2 & 0.1 & $\mathrm{mg} / \mathrm{L}$ \\
\hline Nitrate (as Nitrogen) & EPA-300.0 & 0.028 & $\mathrm{mg} / \mathrm{L}$ \\
\hline Sulfate & EPA-300.0 & 0.25 & $\mathrm{mg} / \mathrm{L}$ \\
\hline MefalslCations $/$ onnitered $\&$ Filtered 4 : & 18.8 .8$. & \% & $1 \%$ \\
\hline $\begin{array}{ll}\text { Aluminum } \\
\end{array}$ & EPA-6010A & $0.02 / 0.2$ & $\mathrm{mg} / \mathrm{L}$ \\
\hline Antimony & EPA-6010A/ -200.8 & $0.05 / 0.0005$ & $\mathrm{mg} / \mathrm{L}$ \\
\hline Arsenic & EPA-200.8 & 0.005 & $\mathrm{mg} / \mathrm{L}$ \\
\hline Barium & EPA-6010A & $0.001 / 0.004$ & $\mathrm{mg} / \mathrm{L}$ \\
\hline Beryllium & EPA-6010A & $0.0003 / 0.001$ & $\mathrm{mg} / \mathrm{L}$ \\
\hline Boron & EPA-6010A & $0.004 / 0.1$ & $\mathrm{mg} / \mathrm{L}$ \\
\hline Cadmium & EPA-6010A -200.8 & $0.003 / 0.0005$ & $\mathrm{mg} / \mathrm{L}$ \\
\hline Calcium & EPA-6010A & $0.008 / 0.2$ & $\mathrm{mg} / \mathrm{L}$ \\
\hline Chromium & EPA-6010A & $0.01 / 0.02$ & $\mathrm{mg} / \mathrm{L}$ \\
\hline Cobalt & EPA-6010A & $0.005 / 0.02$ & $\mathrm{mg} / \mathrm{L}$ \\
\hline Copper & EPA-6010A & $0.004 / 0.02$ & $\mathrm{mg} / \mathrm{L}$ \\
\hline Iron & EPA-6010A & $0.005 / 0.05$ & $\mathrm{mg} / \mathrm{L}$ \\
\hline Lead & EPA-200.8 & 0.0005 & $\mathrm{mg} / \mathrm{L}$ \\
\hline Lithium & EPA-6010A & $0.004 / 0.01$ & $\mathrm{mg} / \mathrm{L}$ \\
\hline Magnesium & EPA-6010A & $0.003 / 0.2$ & $\mathrm{mg} / \mathrm{L}$ \\
\hline Manganese & EPA-6010A & $0.001 / 0.005$ & $\mathrm{mg} / \mathrm{L}$ \\
\hline Mercury & EPA-7470 & 0.0002 & $\mathrm{mg} / \mathrm{L}$ \\
\hline Molybdenum & EPA-6010A & $0.01 / 0.05$ & $\mathrm{mg} / \mathrm{L}$ \\
\hline
\end{tabular}


Table 3 (continued)

\begin{tabular}{|c|c|c|c|}
\hline 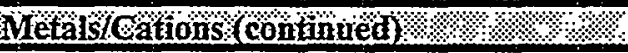 & Anatyuticalyetiodo & sefection MLinit & Uaits $^{3}$ \\
\hline Nickel & EPA-6010A & $0.01 / 0.05$ & $\mathrm{mg} / \mathrm{L}$ \\
\hline Potassium & EPA-6010A & $0.6 / 2$ & $\mathrm{mg} / \mathrm{L}$ \\
\hline Selenium & EPA-6010A/-200.8 & $0.05 / 0.01$ & $\mathrm{mg} / \mathrm{L}$ \\
\hline Silver & EPA-6010A & $0.006 / 0.02$ & $\mathrm{mg} / \mathrm{L}$ \\
\hline Sodium & EPA-6010A & $0.02 / 0.2$ & $\mathrm{mg} / \mathrm{L}$ \\
\hline Strontium & EPA-6010A & $0.0004 / 0.005$ & $\mathrm{mg} / \mathrm{L}$ \\
\hline Thallium & EPA-200.8 & 0.0005 & $\mathrm{mg} / \mathrm{L}$ \\
\hline Thorium & EPA-6010A & 0.2 & $\mathrm{mg} / \mathrm{L}$ \\
\hline Uranium & EPA-200.8 & 0.0005 & $\mathrm{mg} / \mathrm{L}$ \\
\hline Vanadium & EPA-6010A & $0.005 / 0.02$ & $\mathrm{mg} / \mathrm{L}$ \\
\hline Zinc & EPA-6010A & $0.002 / 0.05$ & $\mathrm{mg} / \mathrm{L}$ \\
\hline Volatile Organiecoompounds. & \%?: & QROLW\% & \%.\% \\
\hline $\begin{array}{ll}\text { Acetone } \\
\text { Act }\end{array}$ & EPA-8260 & 10 & $\mu \mathrm{g} / \mathrm{L}$ \\
\hline Acrolein & EPA-8260 & 10 & $\mu \mathrm{g} / \mathrm{L}$ \\
\hline Acrylonitrile & EPA-8260 & 10 & $\mu \mathrm{g} / \mathrm{L}$ \\
\hline Benzene & EPA-8260 & 5 & $\mu \mathrm{g} / \mathrm{L}$ \\
\hline Bromochloromethane & EPA-8260 & 10 & $\mu \mathrm{g} / \mathrm{L}$ \\
\hline Bromodichloromethane & EPA-8260 & 5 & $\mu \mathrm{g} / \mathrm{L}$ \\
\hline Bromoform & EPA-8260 & 5 & $\mu \mathrm{g} / \mathrm{L}$ \\
\hline Bromomethane & EPA-8260 & 10 & $\mu \mathrm{g} / \mathrm{L}$ \\
\hline 2-Butanone & $E P A_{1}-8260$ & 10 & $\mu \mathrm{g} / \mathrm{L}$ \\
\hline Carbon disulfide & EPA-8260 & 5 & $\mu \mathrm{g} / \mathrm{L}$ \\
\hline Carbon tetrachloride & EPA-8260 & 5 & $\mu \mathrm{g} / \mathrm{L}$ \\
\hline Chlorobenzene & EPA-8260 & 5 & $\mu \mathrm{g} / \mathrm{L}$ \\
\hline Chloroethane & EPA-8260 & 10 & $\mu \mathrm{g} / \mathrm{L}$ \\
\hline 2-Chloroethyl vinyl ether & EPA-8260 & 10 & $\mu \mathrm{g} / \mathrm{L}$ \\
\hline Chloroform & EPA-8260 & 5 & $\mu \mathrm{g} / \mathrm{L}$ \\
\hline Chloromethane & EPA- 8260 & 10 & $\mu \mathrm{g} / \mathrm{L}$ \\
\hline Dibromochloromethane & EPA-8260 & 5 & $\mu \mathrm{g} / \mathrm{L}$ \\
\hline 1,2-Dibromo-3-chloropropane & EPA-8260 & 10 & $\mu \mathrm{g} / \mathrm{L}$ \\
\hline 1,2-Dibromoethane & EPA-8260 & 5 & $\mu \mathrm{g} / \mathrm{L}$ \\
\hline Dibromomethane & EPA-8260 & 10 & $\mu \mathrm{g} / \mathrm{L}$ \\
\hline 1,2-Dichlorobenzene & EPA-8260 & 5 & $\mu \mathrm{g} / \mathrm{L}$ \\
\hline 1,4-Dichlorobenzene & EPA-8260 & 5 & $\mu \mathrm{g} / \mathrm{L}$ \\
\hline 1,4-Dichloro-2-butene & EPA-8260 & 5 & $\mu \mathrm{g} / \mathrm{L}$ \\
\hline trans-1,4-Dichloro-2-butene & EPA- 8260 & 5 & $\mu \mathrm{g} / \mathrm{L}$ \\
\hline Dichlorodifluoromethane & EPA-8260 & 5 & $\mu \mathrm{g} / \mathrm{L}$ \\
\hline 1,1-Dichloroethane & EPA-8260 & 5 & $\mu \mathrm{g} / \mathrm{L}$ \\
\hline 1,2-Dichloroethane & EPA-8260 & 5 & $\mu \mathrm{g} / \mathrm{L}$ \\
\hline 1,1-Dichloroethene & EPA-8260 & 5 & $\mu \mathrm{g} / \mathrm{L}$ \\
\hline 1,2-Dichloroethene & EPA-8260 & 5 & $\mu \mathrm{g} / \mathrm{L}$ \\
\hline
\end{tabular}


Table 3 (continued)

\begin{tabular}{|c|c|c|c|}
\hline Volatileorganiceompounds $/$ conat d $/$ / & AnalyticalbMethod? & CROP $8:$ & Enits ${ }^{3}$ \\
\hline cis-1,2-Dichloroethene & EPA- 8260 & 5 & $\mu \mathrm{g} / \mathrm{L}$ \\
\hline trans-1,2-Dichloroethene & EPA-8260 & 5 & $\mu \mathrm{g} / \mathrm{L}$ \\
\hline 1,2-Dichloropropane & EPA-8260 & 5 & $\mu \mathrm{g} / \mathrm{L}$ \\
\hline cis-1,3-Dichloropropene & EPA-8260 & 5 & $\mu \mathrm{g} / \mathrm{L}$ \\
\hline trans-1,3-Dichloropropene & $\mathrm{EPA}-8260$ & 5 & $\mu \mathrm{g} / \mathrm{L}$ \\
\hline Dimethylbenzene & EPA-8260 & 5 & $\mu \mathrm{g} / \mathrm{L}$ \\
\hline Ethanol & EPA-8260 & 500 & $\mu \mathrm{g} / \mathrm{L}$ \\
\hline Ethylbenzene & EPA-8260 & 5 & $\mu \mathrm{g} / \mathrm{L}$ \\
\hline Ethyl methacrylate & EPA-8260 & 5 & $\mu \mathrm{g} / \mathrm{L}$ \\
\hline 2-Hexanone & $\mathrm{EPA}-8260$ & 10 & $\mu \mathrm{g} / \mathrm{L}$ \\
\hline Iodomethane & $\mathrm{EPA}-8260$ & 5 & $\mu \mathrm{g} / \mathrm{L}$ \\
\hline 4-Methyl-2-pentanone & EPA-8260 & 10 & $\mu \mathrm{g} / \mathrm{L}$ \\
\hline Methylene chloride & EPA-8260 & 5 & $\mu \mathrm{g} / \mathrm{L}$ \\
\hline Styrene & EPA-8260 & 5 & $\mu \mathrm{g} / \mathrm{L}$ \\
\hline 1,1,1,2-Tetrachloroethane & EPA-8260 & 10 & $\mu \mathrm{g} / \mathrm{L}$ \\
\hline 1,1,2,2-Tetrachloroethane & EPA-8260 & 5 & $\mu \mathrm{g} / \mathrm{L}$ \\
\hline Tetrachloroethene & EPA-8260 & 5 & $\mu g / L$ \\
\hline $\begin{array}{r}\text { Toluene } \\
\end{array}$ & EPA-8260 & 5 & $\mu \mathrm{g} / \mathrm{L}$ \\
\hline 1,1,1-Trichloroethane & $\mathrm{EPA}-8260$ & 5 & $\mu \mathrm{g} / \mathrm{L}$ \\
\hline 1,1,2-Trichloroethane & EPA-8260 & 5 & $\mu \mathrm{g} / \mathrm{L}$ \\
\hline Trichloroethene & $\mathrm{EPA}-8260$ & 5 & $\mu \mathrm{g} / \mathrm{L}$ \\
\hline Trichlorofluoromethane & EPA-8260 & 5 & $\mu \mathrm{g} / \mathrm{L}$ \\
\hline 1,2,3-Trichloropropane & EPA-8260 & 5 & $\mu \mathrm{g} / \mathrm{L}$ \\
\hline Vinyl acetate & EPA-8260 & 10 & $\mu \mathrm{g} / \mathrm{L}$ \\
\hline Vinyl chloride & EPA-8260 & 10 & $\mu \mathrm{g} / \mathrm{L}$ \\
\hline 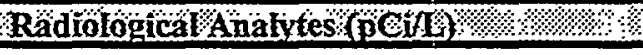 & \%४४ & Target:MDA 6 & \% \\
\hline Gross Alpha Activity & EPA-900.0 & 3.5 & $\mathrm{pCi} / \mathrm{L}$ \\
\hline Gross Beta Activity & EPA-900.0 & 7.0 & $\mathrm{pCi} / \mathrm{L}$ \\
\hline Americium-241 & AC-MM-2-22012 & 0.4 & $\mathrm{pCi} / \mathrm{L}$ \\
\hline Iodine-129 & EPA-901.1 & 3.0 & $\mathrm{pCi} / \mathrm{L}$ \\
\hline Neptunium-237 & Y/P65-7206 & 0.4 & $\mathrm{pCi} / \mathrm{L}$ \\
\hline Plutonium-238 \& -239/240 & AC-MM-2-22012 & 0.4 & $\mathrm{pCi} / \mathrm{L}$ \\
\hline Radium-223/224/226 & EPA-903.0 & 0.5 & $\mathrm{pCi} / \mathrm{L}$ \\
\hline Strontium-89/90 & EPA-905.0 & 4.0 & $\mathrm{pCi} / \mathrm{L}$ \\
\hline Technetium-99 & Y/P65-7154 & 10 & $\mathrm{pCi} / \mathrm{L}$ \\
\hline Tritium & EPA-906.0 & 300 & $\mathrm{pCi} / \mathrm{L}$ \\
\hline Uranium-234, 235, \& 238 & AC-MM-2-22012 & 0.4 & $\mathrm{pCi} / \mathrm{L}$ \\
\hline
\end{tabular}




\section{Table 3 (continued)}

\section{Notes:}

1 The analytical method for three trace metals (antimony, cadmium, and selenium) changed from inductively coupled plasma spectroscopy to inductively coupled plasma mass spectroscopy, effective April 1, 1998, to obtain lower detection limits. Analytical/field methods/procedures from:

- Test Methods for Evaluating Solid Waste Physical/Chemical Methods (U.S. Environmental Protection Agency 1986)

- Methods for Chemical Analysis of Water and Wastes (U.S. Environmental Protection Agency 1983)

- Environmental Surveillance Procedures Quality Control Manual (Lockheed Martin Energy Systems, Inc. 1988)

- Lockheed Martin Energy Systems ASO radiological methods

2 NA - not applicable

Detection limits for metals/cations by Inductively Coupled Plasma spectroscopy changed during the second quarter sampling event. The first detection limit was used until April; the second one listed was used thereafter.

$3 \mathrm{ft}$ - feet

$\mu \mathrm{g} / \mathrm{L}$ - micrograms per liter

$\mu \mathrm{mho} / \mathrm{cm}$ - micromhos per centimeter

$\mathrm{mg} / \mathrm{L}$ - milligrams per liter

$\mathrm{mV}$ - millivolts

NTU - nephelometric turbidity units

ppm - parts per million

$\mathrm{pCi} / \mathrm{L}$ - picoCuries per liter

4 Samples for dissolved metals analysis were collected using a 0.45 -micron filter.

5 CRQL - contract-required quantitation limit

6 MDA - minimum detectable activity. The target MDA may be obtained under optimal analytical conditions; actual MDAs are samplespecific and may vary significantly from the target value. 
Table 4. CY 1998 maximum summed VOC concentrations in groundwater samples

\begin{tabular}{|c|c|c|c|c|c|c|c|c|}
\hline \multicolumn{3}{|c|}{ Monitoring Well } & \multirow{2}{*}{$\begin{array}{l}\text { Summed } \\
\text { vOCs }\end{array}$} & \multicolumn{3}{|c|}{ Chlorinated Solvents ${ }^{2}$} & \multirow{2}{*}{$\begin{array}{l}\text { Petroleum } \\
\text { Hydrocarb. }\end{array}$} & \multirow{2}{*}{$\begin{array}{l}\text { Miscell- } \\
\text { aneous }\end{array}$} \\
\hline Number & Location ${ }^{1}$ & Date & & Ethenes & Ethanes & Methanes & & \\
\hline \multicolumn{3}{|c|}{ AQUITARD } & & & & & & \\
\hline GW-008 & OLF & $7 / 20 / 98$ & 56 & 42 & 8 & 0 & 2 & 4 \\
\hline GW-046 & BG & $7 / 22 / 98$ & 15,260 & 14,843 & 324 & 22 & 57 & 14 \\
\hline GW-276 & S3 & $1 / 22 / 98$ & 12 & 12 & 0 & 0 & 0 & 0 \\
\hline GW-287. & $B G$ & $3 / 2 / 98$ & 5 & 5 & 0 & 0 & 0 & 0 \\
\hline GW-537 & OLF & $8 / 31 / 98$ & 2 & 0 & 0 & 2 & 0 & 0 \\
\hline GW-627 & $\mathrm{BG}$ & 9/1/98 & 396 & 358 & 38 & 0 & 0 & 0 \\
\hline GW-653 & $\mathrm{BG}$ & $3 / 10 / 98$ & 29 & 27 & 2 & 0 & 0 & 0 \\
\hline \multicolumn{3}{|c|}{ AQUIFER } & & & & & & \\
\hline GW-053 & BG & $9 / 2 / 98$ & 31 & 25 & 6 & 0 & 0 & 0 \\
\hline GW-056 & EXP-A & $7 / 27 / 98$ & 9 & 9 & 0 & 0 & 0 & 0 \\
\hline GW-226 & OLF & $9 / 2 / 98$ & 188 & 183 & 0 & 5 & 0 & 0 \\
\hline GW-311 & $\mathrm{RS}$ & $8 / 27 / 98$ & 12 & 10 & 0 & 2 & 0 & 0 \\
\hline GW-315 & SPI & $3 / 2 / 98$ & 23 & 23 & 0 & 0 & 0 & 0 \\
\hline GW-695 & EXP-B & $2 / 17 / 98$ & 9 & 9 & 0 & 0 & 0 & 0 \\
\hline GW-703 & EXP-B & $2 / 16 / 98$ & 28 & 27 & 0 & 0 & 1 & 0 \\
\hline GW-704 & EXP-B & $8 / 13 / 98$ & 92 & 89 & 2 & 1 & 0 & 0 \\
\hline GW-706 & EXP-B & $8 / 10 / 98$ & 20 & 20 & 0 & 0 & 0 & 0 \\
\hline GW-724 & EXP-C & $3 / 5 / 98$ & 137 & 137 & 0 & 0 & 0 & 0 \\
\hline GW-725 & EXP-C & $3 / 10 / 98$ & 50 & 49 & 0 & 1 & 0 & 0 \\
\hline GW-738 & EXP-C & $3 / 4 / 98$ & 39 & 39 & 0 & 0 & 0 & 0 \\
\hline GW-740 & EXP-C & $3 / 4 / 98$ & 79 & 75 & 1 & 3 & 0 & 0 \\
\hline
\end{tabular}

\section{Notes:}

1 BG - Bear Creek Burial Grounds Waste Management Area

EXP-A - Exit Pathway (Maynardville Limestone) Picket A

EXP-B - Exit Pathway Picket B

EXP-C - Exit Pathway Picket C

OLF - Oil Landfarm Waste Management Area

RS - Rust Spoil Area

SPI - Spoil Area I

S3 - S-3 Site

2 Sum of all VOCs, in micrograms per liter. Only results with a sum greater than zero are shown on the table. 
3 Ethenes - Summed chloroethenes (PCE, TCE, cis-1,2-DCE, trans-1,2-DCE, 1,1-DCE, 1,1-DCE, vinyl chloride)

Ethanes - Summed chloroethanes (1,1,1-TCA, 1,2-DCA, 1,1-DCA, chloroethane)

Methanes - Summed chloromethanes (carbon tetrachloride, chloroform, methylene chloride)

4 Petroleum hydrocarbons are benzene and dimethylbenzene (xylenes).

5 Miscellaneous compounds are acetone, 2-butanone, 1,2-dibromoethane,1,2-dichloropropane, and trichlorofluoromethane. 
Table 5. CY 1998 gross alpha and gross beta activity in groundwater and surface water samples

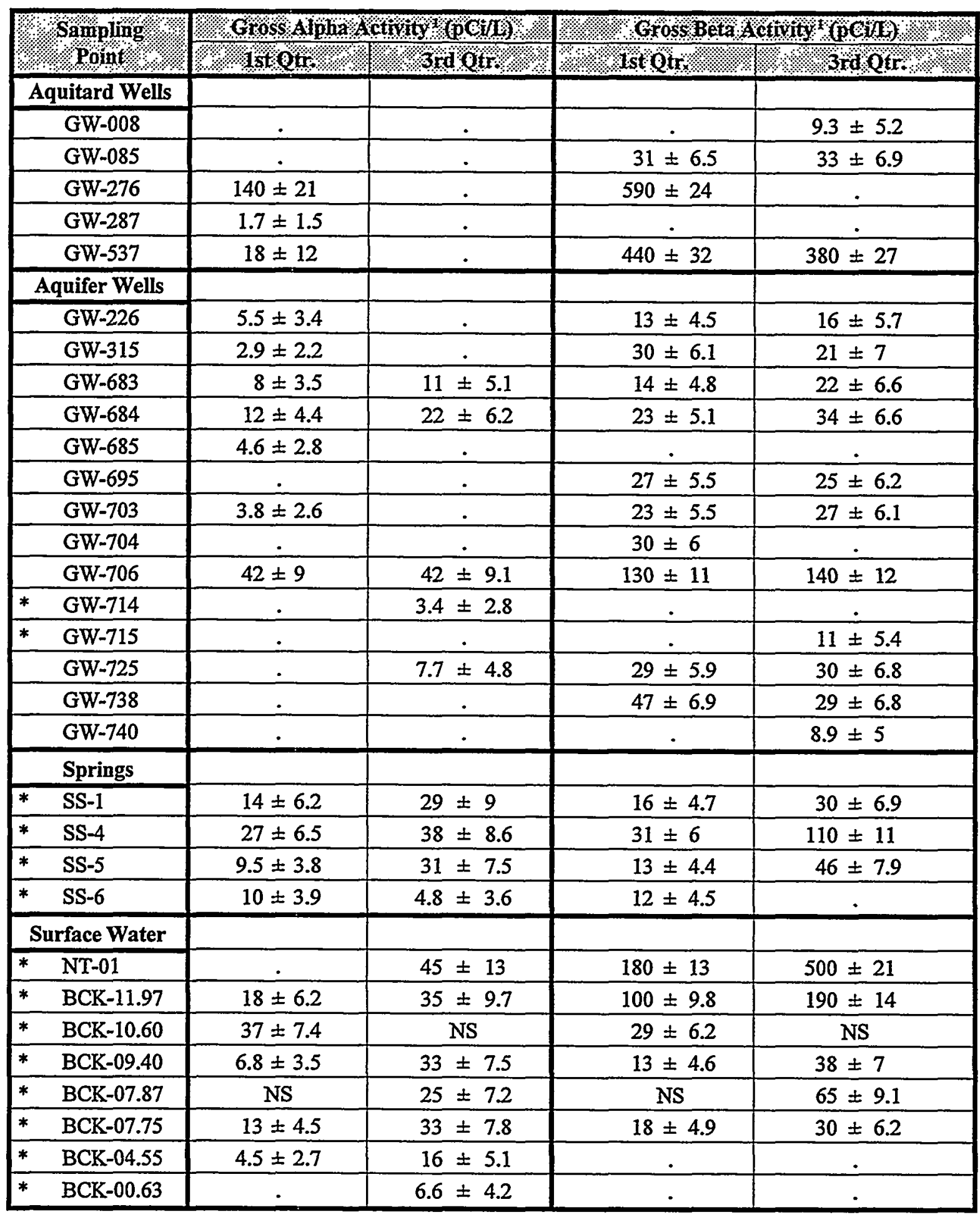




\section{Table 5 (continued)}

\section{Notes:}

1 Activity, reported in picoCuries per liter $(\mathrm{pCi} / \mathrm{L})$, that exceeded the error associated with the result and the sample-specific minimum detectable activity (MDA).

- Result less than the MDA or the associated error.

NS - Not sampled.

* - Exit Pathway/Perimeter Monitoring location. 


\section{DISTRIBUTION}

U.S. DEPARTMENT OF ENERGY

D.G. Adler

J.D. Darby

J.P. Donnelly

M.S. Ferre

ENVIRONMENTAL COMPLIANCE

DEPARTMENT

S.M. Field

S.B. Jones

C.C. Hill

J.E. Powell

E.B. Rundle

L.O. Vaughan

GWPP-File-RC (2)

LOCKHEED MARTIN

ENERGYRESEARCH

R.H. Ketelle

D.B. Watson
ANALYTICAL SERVICES

ORGANIZATION

D.D. Altom

BECHTEL JACOBS COMPANY LLC

M.L. Allen (2)

C.S. Haase (2)

H.L. King

File-EMEF-DMC

SCIENCE APPLICATIONS

INTERNATIONAL CORPORATION

W.K. Jago

TENNESSEE DEPARTMENT OF

ENVIRONMENT AND

CONSERVATION -

DOE OVERSIGHT DIVISION

D. Gilmore (3)

Y-12 Central Files

Y-12 Plant Records Services (2) 9711-5, MS-8169 [2 copies for OSTI] 